Portland State University

PDXScholar

1982

\title{
Geology and hydrothermal alteration, Glass Buttes, Southeast Oregon
}

Dulcy Annette Berri

Portland State University

Follow this and additional works at: https://pdxscholar.library.pdx.edu/open_access_etds

Part of the Geology Commons, and the Volcanology Commons Let us know how access to this document benefits you.

Recommended Citation

Berri, Dulcy Annette, "Geology and hydrothermal alteration, Glass Buttes, Southeast Oregon" (1982). Dissertations and Theses. Paper 3158.

https://doi.org/10.15760/etd.3147

This Thesis is brought to you for free and open access. It has been accepted for inclusion in Dissertations and Theses by an authorized administrator of PDXScholar. Please contact us if we can make this document more accessible: pdxscholar@pdx.edu. 
AN ABSTRACT OF THE THESIS OF Dulcy A. Berri for the Master of Science in Geology presented May 17, 1982.

Title: Geology and Hydrothermal Alteration, Glass Buttes, Southeast Oregon.

APPROVED BY MEMBERS OF THE THESIS COMMITTEE:
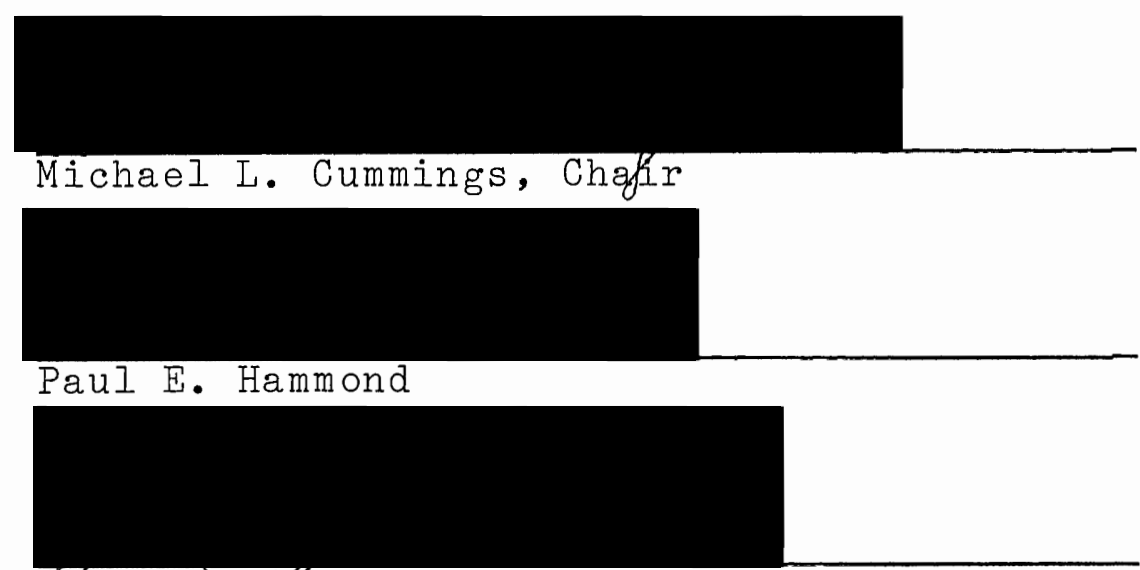

AYsel G. IJhnson

The Glass Buttes volcanic complex consists of many domes and individual vents that erupted both rhyolitic and basaltic lavas during the late Miocene to early Pliocene. The east half of the complex, in the vicinity of Little Glass Butte, contains interfingering, finely flow-banded rhyolite and black obsidian flows. The youngest unit, an obsidian, has been dated at $4.9 \mathrm{~m} \cdot \mathrm{y}$. East of Little Glass Butte lie two northwest-trending ridges, Antelope and Cascade Ridges, composed of two or more overlapping exogenous domes that formed along nุorthwest-trending faults. 
The Brothers fault zone dominates local structure. Fault trends observed are northwesterly, and nor theast trends may be conjugate fractures. The concentration of volcanism at Glass Buttes may be due to intersection of the Brothers fault zone with a west-northwest-trending silicic volcanic zone. Ensuing volcanism was bimodal, including glassy rhyolite, and the igneous body fostered a hydrothermal system. Rhyolites are peraluminous, and silica ranges from 73 to $79 \%$. Growth of spherulites occurred during devitrification of the glassy rhyolites, with slight silicaenrichment during vapor-phase alteration. Hydration and groundwater leaching depleted soda, alumina and silica in the glass. The plateau surrounding the buttes consists of olivine basalt, and a feldspathic basalt interfingers with rhyolite flows within the complex.

Hydrothermal alteration of rhyolite flows and glass was concentrated along faults in the eastern Glass Buttes. Massive cinnabar-bearing opalite was deposited from rising silica-rich geothermal waters accompanied by mercury-bearing vapors. Silicification occurred into footwall material, and irregular argillic alteration resulted from downward-percolating acidified groundwater.

The hydrothermal system has since cooled off or been plugged by opalite deposits. Eruption of lavas continued after alteration, further sealing the system. Late-stage fumarolic alteration indicates limited escape of gases occurred through faults in the opalite. 
The geothermal reservoir is $600 \mathrm{~m}$ or more below the surface. Repeated fracturing and resultant boiling of fluids suggests the potential for precious metal deposits. Low temperature fluids producing surface alteration could not transport most epithermal elements, that subsequently were concentrated below the opalite cover. The steeply inclined zones of alteration imply a deep hydrothermal system, and great depths to potentially economic mineral deposits. 
GEOLOGY AND HYDROTHERMAL ALTERATION

GLASS BUTTES, SOUTHEAST OREGON

\author{
by \\ DULCY ANNETTE BERRI
}

A thesis submitted in partial fulfillment of the requirements for the degree of

\author{
MASTER OF SCIENCE \\ in \\ GEOLOGY
}

Portland State University

1982 
TO THE OFFICE OF GRADUATE STUDIES AND RESEARCH:

The members of the Committee approve the thesis of Dulcy Annette Berri presented May 17, 1982.

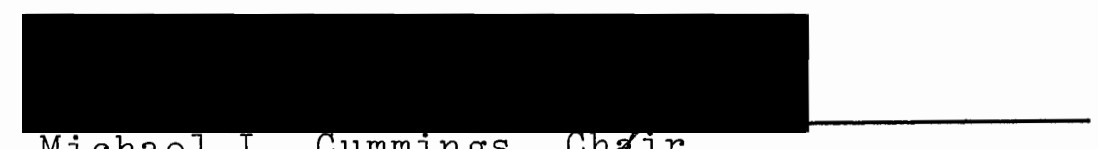

Michael L. Cummings, Chælir

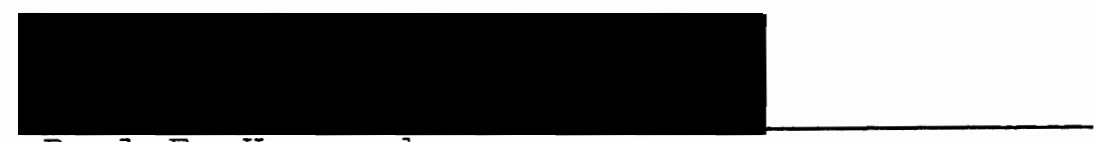

Paul E. Hammond

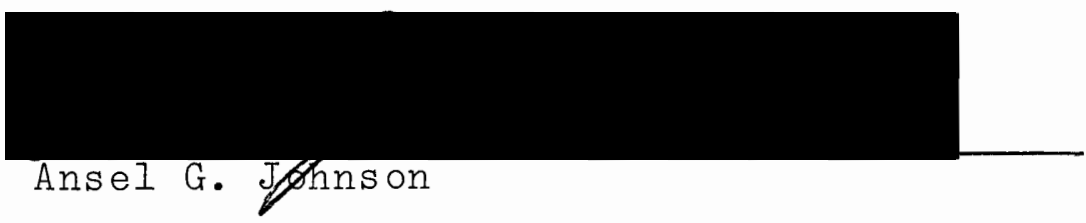

APPROVED:

GiUbert T: Benson, Head, Department of Earth Sciences

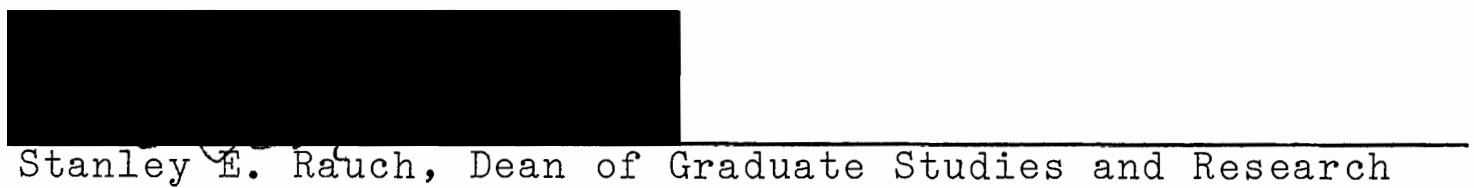




\section{ACKNOWLEDGMENTS}

I am greatly indebted to Michael L. Cummings for the impetus his enthusiasm and conscientious guidance gave me throughout this study. I am also grateful to R. T. Forest and Phillips Petroleum Company for funding that made this investigation possible. Dick Benoit must be recognized for his assistance in obtaining the grant, for helping in many aspects of the research, and for critically reviewing the manuscript. Paul Hammond, Ansel Johnson and John Allen have also carefully examined this thesis, and their comments have resulted in a clearer, more tightly organized and meaningful report. David Brown and Eugene Ciancanelli provided assistance in the early phases of this study. The generous cooperation of Chuck Lytle and Peter Hooper made chemical analyses possible. I'm thankful to the entire faculty, staff, fellow students and friends in the Earth Science Department for their interest and unflagging support. Finally, this study would not have been possible without the confidence and financial and moral support of Greg McInnis, nor without Bud, who protected me from rattlesnakes. 
TABLE OF CONTENTS

PAGE

ACKNOWLEDGMENTS • • • • • • • • • • • • • • •

LIST OF TABLES • • • • • • • • • • • • •

vii

LIST OF FIGURES • • • • • • • • • • • • •

viii

INTRODUCTION • • • • • • • • • • • • • •

Purpose and Scope . • • • • • • • • •

Methods . . . . . . . . . . • •

Location and Accessibility . . • • • •

Previous Work . . . . . . . . • •

REGIONAL GEOLOGY • • • • • • • • • • • •

Regional Setting . . . . . . . • • •

General Geologic History . . . . . •

Tectonic Setting • • • • . . • • • •

Regional Stratigraphy . . . . . • • •

Lithologic Groups at Glass Buttes . • •

Flows

Exogenous Domes

Endogenous Domes

Airfall Tuff

Basalt

Volcaniclastic Sediments

Summary of Stratigraphy • • • • • • • • 
Lineaments

Faults

Joints

Relation of Local to Regional Structures. •

Chemical Characteristics . • . • • •

Devitrification and Hydration . . . . . 67

Discussion . . . . . . . . . . 68

HYDROTHERMAL ALTERATION • • • • • • • • •

Altered Surface Rocks . . . . • • •

Opalized Rhyolite

Opalized Tuff

Argillic Alteration

Fumarolic Alteration

Bleached Rocks

Sulfides

Hyalite

Structures Related to Alteration . . •

Cascade Ridge

Antelope Ridge

Discussion

Chemistry of Alteration . • • • • • •

Opalite Deposition

Silica and Mercury-bearing Solutions

Subsurface Alteration

ECONOMIC ASPECTS OF GLASS BUTTES • • • • • •

Cinnabar Deposits . . . . . . . • •

Geothermal Exploration . . . . . • •

Model of the Geothermal Reservoir . . . . 
SUMMARY AND CONCLUSIONS • • • • • • • • • • • • 


\section{LIST OF TABLES}

TABLE

PAGE

I Summary of Iithologic types . . . . . . . 22

II Summary of structures in the eastern Glass Buttes 59

III Chemical analyses . . . . . . . . . . 62

IV Chemical analyses of silicified rocks . . . • 85 


\section{LIST OF FIGURES}

FIGURE

1. Location of Glass Buttes . • . • . . • . 4

2. Sketch map of the study area . . . . . . 5

3. Physiographic provinces of southeast Oregon .. 9

4. Structural setting . . . . . . . . . 12

5. General stratigraphic correlation chart • • 17

6. Contorted flow banding . . . . . . . . 23

7. Spherulites, older Little Glass Butte rhyolite 25

8. X-ray diffraction patterns, Little Glass Butte rhyolites • . • • . . . . . . . 26

9. Platy jointing • • • • • • • • • • • 28

10. Obsidian outcrop • • • • • • • • • • • 30

11. Obsidian varieties . • . • . . • . . 31

12. Cascade Ridge fault valley . • . • . • • . 36

13. Plateau basalt photomicrograph • • • • • • 39

14. Lineaments and faults . . . . . . . . • . 49

15. Stereograms of poles to joints, eastern study area • • . . . . . . . . . . 52

16. Stereograms of poles to joints, western study area • • • • • • • • • • . . 54

17. Successive development of surface structures • . 58 18. Major oxide variations versus silica • • • • • 64 19. AF'M plot • • • • • • • • • • • . 66 
FIGURE:

PAGE

20். Incomplete opalization of rhyolitic glass • • •

72

21. Leached opalite . • . • • • • • • • •

74

22. X-ray diffraction pattern

75

23. Stained pumice blocks .

24. Cascade mine .....

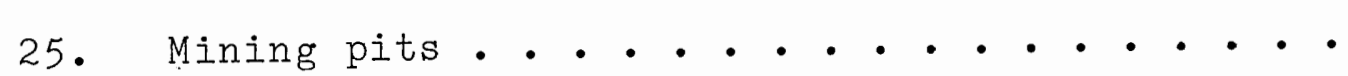

26. Geographic distribution of major oxide

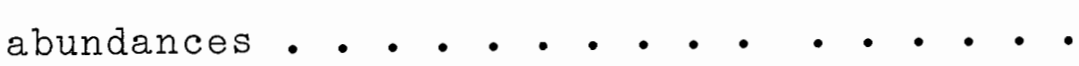

27. Variation of $\mathrm{TiO}_{2}$ and $\mathrm{MgO}$ versus $\mathrm{SiO}_{2} \cdot$ • • •

28. Generalized Iithologic logs . . . . . . . . 


\section{INTRODUCTION}

\section{PURPOSE AND SCOPE}

The High Lava Plains province of central and eastern Oregon is a volcanic upland dominated by the northwesttrending Brothers fault zone, lava plateaus and volcanic centers of Cenozoic age. A west-northwest-trending zone of silicic dome, vent and caldera complexes crosses the province and intersects the Brothers fault zone. Glass Buttes is a rhyolitic dome and vent complex at the intersection of the Brothers fault $z$ one and the silicic volcanic zone, that has been subjected to hydrothermal alteration and mercury mineralization.

The primary objective of this study was to describe the hydrothermal alteration located in the eastern Glass Buttes and to relate the alteration to cinnabar occurrence, structure and lithology. No published detailed geologic maps were available for the area, thus stratigraphy and structure of rocks outside of the area of alteration were studied first. This included examination of the sequence and styles of eruption from the numerous vents within the area and the degree to which faults localized these vents. Stratigraphic sequences are poorly understood between parts of the field area, but a rigorous study of the discontinuous units might in the future clarify these relations. 
The characteristics of unaltered rocks were compared to altered rocks, within which could occasionally be seen remnant primary textures. Faults and joints were compared to structures outside the hydrothermally altered zones. Drilling chips from stratigraphic test wells drilled by Phillips Petroleum Company were examined to determine the variation of alteration with depth. A model was then developed for the fossil geothermal system, incorporating all field and laboratory data.

\section{METHODS}

Field work was conducted from August through September 1980, and in parts of November, 1980 and November, 1981. Major element chemistry was performed by X-ray fluorescence spectrometry (XRF) by Peter Hooper at Washington State University. Additional analyses were performed using atomic absorption spectrometry (AAS) by the author at Portland State University. This data is tabulated in the Appendix. X-ray diffraction analyses were performed by the author on a General Electric XRD D/F X-ray unit at Portland State University. Petrographic studies of thin sections and polished sections were also completed by the author.

\section{LOCATION AND ACCESSIBILITY}

Located in northeast Lake County, Oregon, $80 \mathrm{~km}$ west of Burns and $128 \mathrm{~km}$ southeast of Bend, Glass Buttes extends over $20 \mathrm{~km}$ in a west-northwesterly direction along State 
Highway 20 (Fig. 1). The maximum elevations of the buttes are Glass Butte, $1946 \mathrm{~m}$ (6385 ft), on the west side of the complex, and Little Glass Butte, $1862 \mathrm{~m}$ (6109 ft), in the central portion (Fig. 2). The elevation of the complex decrealses from these high points to low hills and finally to the sulrounding basalt plateau at about $1200 \mathrm{~m}$ (3940 ft) elevation.

Access to the Glass Buttes area is excellent via Highway 20. The complex is parallel to, and about $1.5 \mathrm{~km}$ south of the highway, and can be reached by several maintained Bureau of Land Management gravel and dirt roads. Due to frequent use by ranchers, hunters and rock collectors, most roads within the buttes are kept passable to non-specialized vehiclies in dry weather.

Many geographic names referred to in this study for locations within Glass Buttes are informal and were derived from local usage or were applied informally by the author.

\section{PREVIOUS WORK}

The western and largest butte was not included in this study.| It was described by Waters (1927a; 1927b) and is herein referred to as Glass Butte. Olivine and augitebearing basalts, interpreted by Waters to be the oldest unit in the area, are locally porphyritic, with labradorite crystals over $2 \mathrm{~cm}$ long. He suggested these basalts might correlate with the Miocene-age Steens Basalt found in the Steens Mountains to the southeast. His Glass Buttes Series 


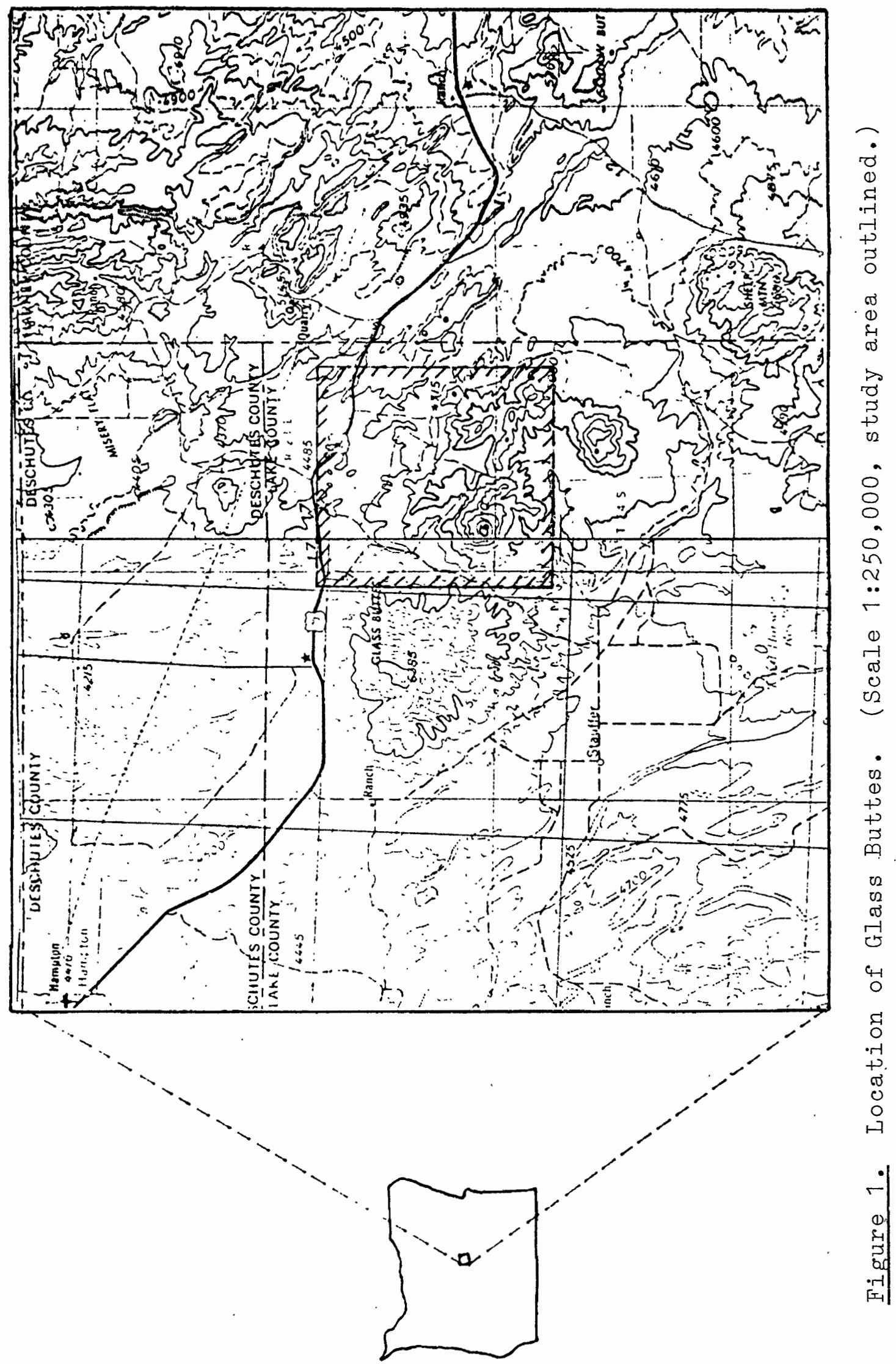




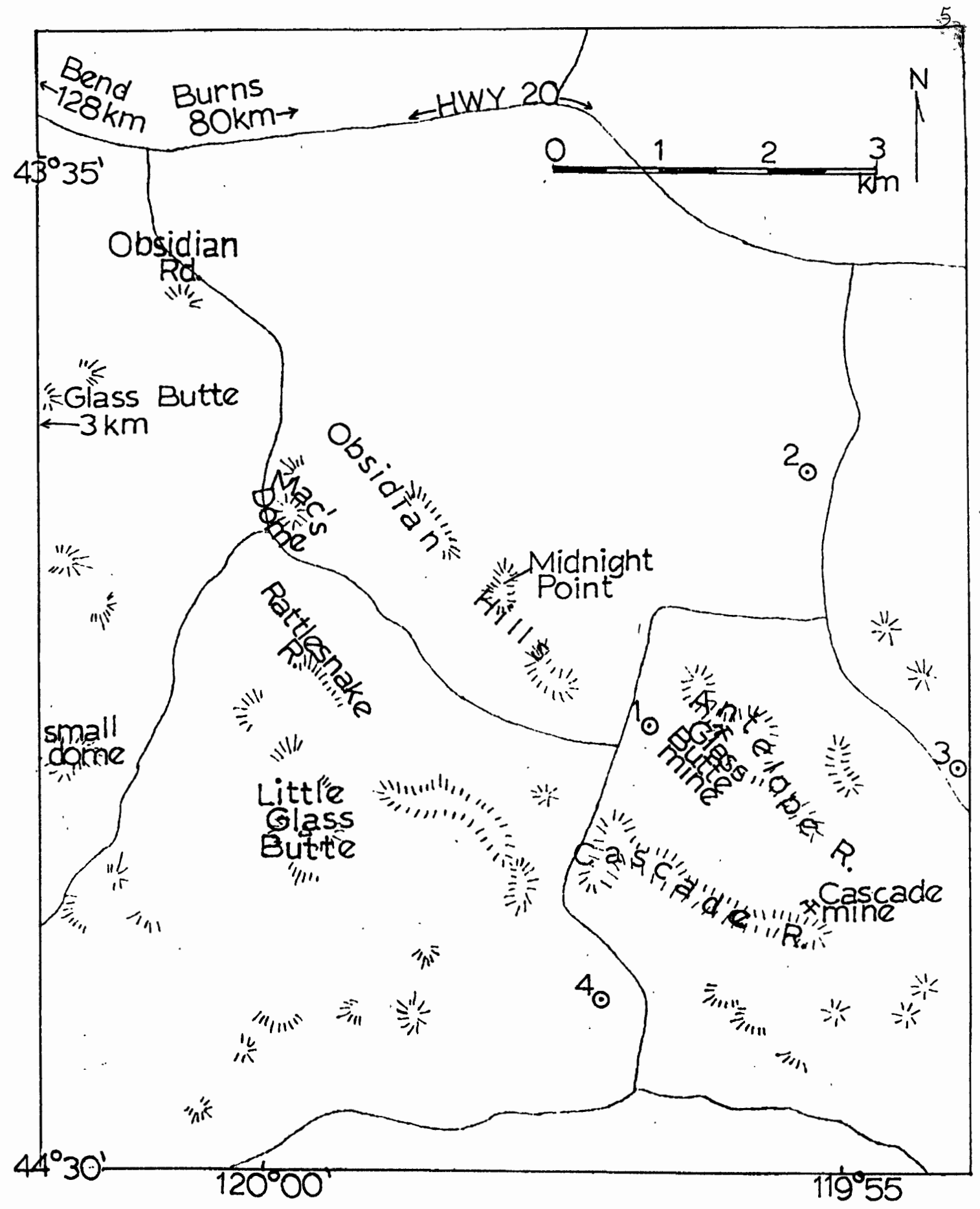

Figure 2. Sketch map of the study area in the eastern Glass Buttes, indicating informal names of features described in this study. Numbered points are drill hole locations. 
overlies the basalts, and consists of over $120 \mathrm{~m}$ of andesite and dacite flows, as well as rhyolitic perlite, obsidian and vitrophyre. Tuffaceous sediments and plateau basalts overlie the Glass Buttes Series. Waters interpreted the structure of the buttes to be that of an anticline whose center has been down-dropped by a system of normal faults, resulting in a west-northwest-trending longitudinal valley that extends across two-thirds of the complex (see Fig. 12). Further study of Glass Buttes was associated with development of mercury mines between 1933 and 1958. Large scale mapping followed, including reconnaissance geologic mapping $(1: 250,000)$ of the Burns Quadrangle (Greene and others, 1972) and the East Half of the Crescent Quadrangle (Walker and others, 1967).

Anthropologists and rock collectors have long been interested in the ubiquitous obsidian at Glass Buttes. Heflin (1963) termed the buttes a "prehistoric munitions factory" for Indians whose ceremonial blades carved from the unique mahogany obsidian have been discovered as far east as burial mounds in Ohio. Today rock collectors seek black lace, mahogany, gold sheen, and rainbow obsidian, and other varieties for collections or gem work.

The most recent geologic interest in Glass Buttes was encouraged by the national energy shortage. K-Ar age determinations of silicic rocks in eastern Oregon defined a westward decrease in age of rhyolitic domes and ash-flow tuffs (Walker, 1974; MacLeod and others, 1976) with a 
potential for discovery of usable geothermal systems in the areas of most recent volcanism. A gradient of $285^{\circ} \mathrm{C} / \mathrm{km}$ was obtained at Newberry caldera at the west end of the silicic volcanic zone (see Geothermal Exploration).

There are no surface manifestations of present thermal activity at Glass Buttes. Four shallow temperature gradient holes drilled in 1975 by the Oregon Department of Geology and Mineral Industries (DOGAMI) indicated a poorly defined zone of high heat flow that appeared to be highest around the areas of most intense hydrothermal alteration in the east half of Glass Buttes (Bowen, 1975). Temperature gradients as high as $190^{\circ} \mathrm{C} / \mathrm{km}$ were detected, including a bottom hole temperature of $48^{\circ} \mathrm{C}$ at a depth of $220 \mathrm{~m}$. This thermal anomaly was investigated by Pheonix Geophysics, Inc., for DOGAMI (Hull, 1976). A dipole-dipole resistivity study indicated generally horizontal lithologic units at depth. Waters' (1927a) interpretation of an anticlinal structure across the complex is not supported by geophysical evidence from the east buttes. The upper-most unit was interpreted in the study to be impermeable volcanic flows from 90 to $600 \mathrm{~m}$ thick that overlie a more permeable, possibly thermal, zone. Phillips Petroleum Company and Francana Resources, Inc., are the latest to investigate the Glass Buttes thermal anomaly. In 1979 and 1980, stratigraphic and temperature gradient test holes were drilled near old mercury mines on the east side of Glass Buttes. 
REGIONAL GEOLOGY

\section{REGIONAL SETTING}

Southern Oregon east of the Cascades was divided by Dicken (1965) into three physiographic provinces: the Basin and Range, the Owyhee Uplands, and the High Lava Plains (Fig. 3). The southern Basin and Range region is characterized by high angle, normal fault-bounded horsts and grabens that are north to northeast-trending, and are cross-cut by numerous northwest-trending faults (Walker, 1973). The Owyhee Uplands to the east is a dissected plateau underlain primarily by Cenozoic volcanic rocks, that has undergone little tectonic deformation other than faulting. Structures trend north-northeasterly as well as northwesterly (Walker, 1973).

The High Lava Plains province (Fig. 3) is a broad expanse of basaltic lava flows, rhyolitic ash-flow tuff, lacustrine and eolian sediments. The flat, high desert country is moderately dissected by intermittent streams and is dotted with hundreds of silicic volcanic centers and basaltic cinder cones that rise to heights as great as $600 \mathrm{~m}$ above the surrounding plateau. Reconnaissance geologic mapping of the region was by Walker and others (1967) and by Greene and others (1972). 


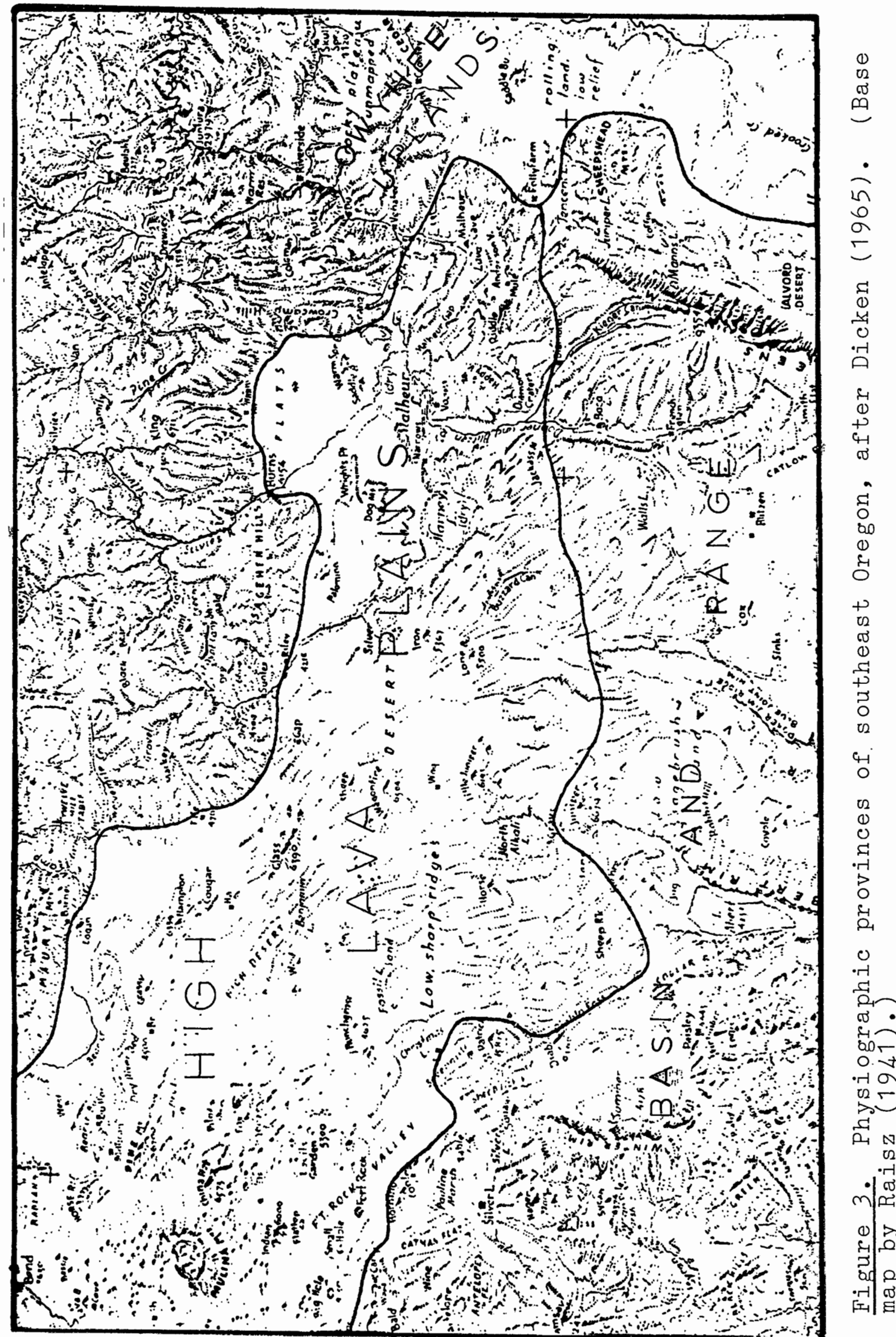


Displacement along faults in southeast Oregon continues to the present. Quaternary basaltic volcanism occurred at Diamond Craters and Jordan Craters. Pleistocene cinder cones and basalt flows in the Klamath Falls area have been offset by Basin and Range faulting (Justus, 1979) and faultrelated thermal springs occur throughout the region (MacLeod and others, 1976). The recent volcanism and deformation suggest considerable geothermal potential exists in southeast Oregon.

\section{GENERAL GEOLOGIC HISTORY}

Eastern Oregon Cenozoic volcanism began in the Eocene and is represented by the subduction-related volcanic rocks of the Clarno Formation, overlain by John Day Formation tuffs (Noblett, 1981). Early to Middle Miocene fissure basalts are correlative with the Columbia River Basalt Group to the north (Walker and others, 1967), and the Steens and Owyhee Basalts to the southeast (Greene and others, 1972). These Miocene basalts were erupted from north-south-trending high-angle faults or fissures throughout central and southeast Oregon. Miocene to Recent bimodal volcanism included fissure basalts and voluminous rhyolite lavas and ash eruptions. Collapse as a result of the Miocene eruption of tremendous volumes of ash formed three calderas in the Harney Basin. These rhyolitic ash-flow eruptions spread 1000 to $2000 \mathrm{~km}^{3}$ of ash over nearly $50,000 \mathrm{~km}^{2}$ (Walker, 1979; Walker and Nolf, 1981). From late Pliocene to Recent time, 
basalt has been erupted from shield volcanoes and fissures. The basalts have buried older volcanic and sedimentary rocks and lap up against older silicic dome and vent complexes (Greene and others, 1972; Walker, 1979).

\section{TECTONIC SETTING}

The structural features of the High. Lava Plains are dominated by the Brothers fault zone, a belt of closely spaced en echelon faults trending $N 60^{\circ} \mathrm{W}$ over $240 \mathrm{~km}$ from near Mount Jefferson in the west to the Oregon-Nevada border (Fig. 4). Also referred to as the Oregon-Nevada lineament (Stewart and others, 1975), the fault zone may continue south-southeast as far as Eureka County, Nevada. It is, however, poorly defined to the southeast beyond the north-northeast-trending Steens Mountain fault in southeast Oregon, and may in fact be terminated by the Steens fault. Lawrence (1976) interprets the Brothers fault zone to be a deeply buried, right-lateral strike-slip fault zone forming the northern boundary of the Basin and Range province. The southern boundary, according to Lawrence (1976), occurs at the left-lateral Garlock fault in southern California. Crust between the two fault zones, i.e. the Basin and Range province, is extending westward.

The Eugene-Denio zone of lineaments, located south of the Brothers fault zone, trends $N 55^{\circ}-60^{\circ} \mathrm{W}$ (Fig. 4). A zone of silicic volcanic centers, trending $175^{\circ}$ $80^{\circ} \mathrm{W}$, extends from Duck Butte west to Newberry caldera. 


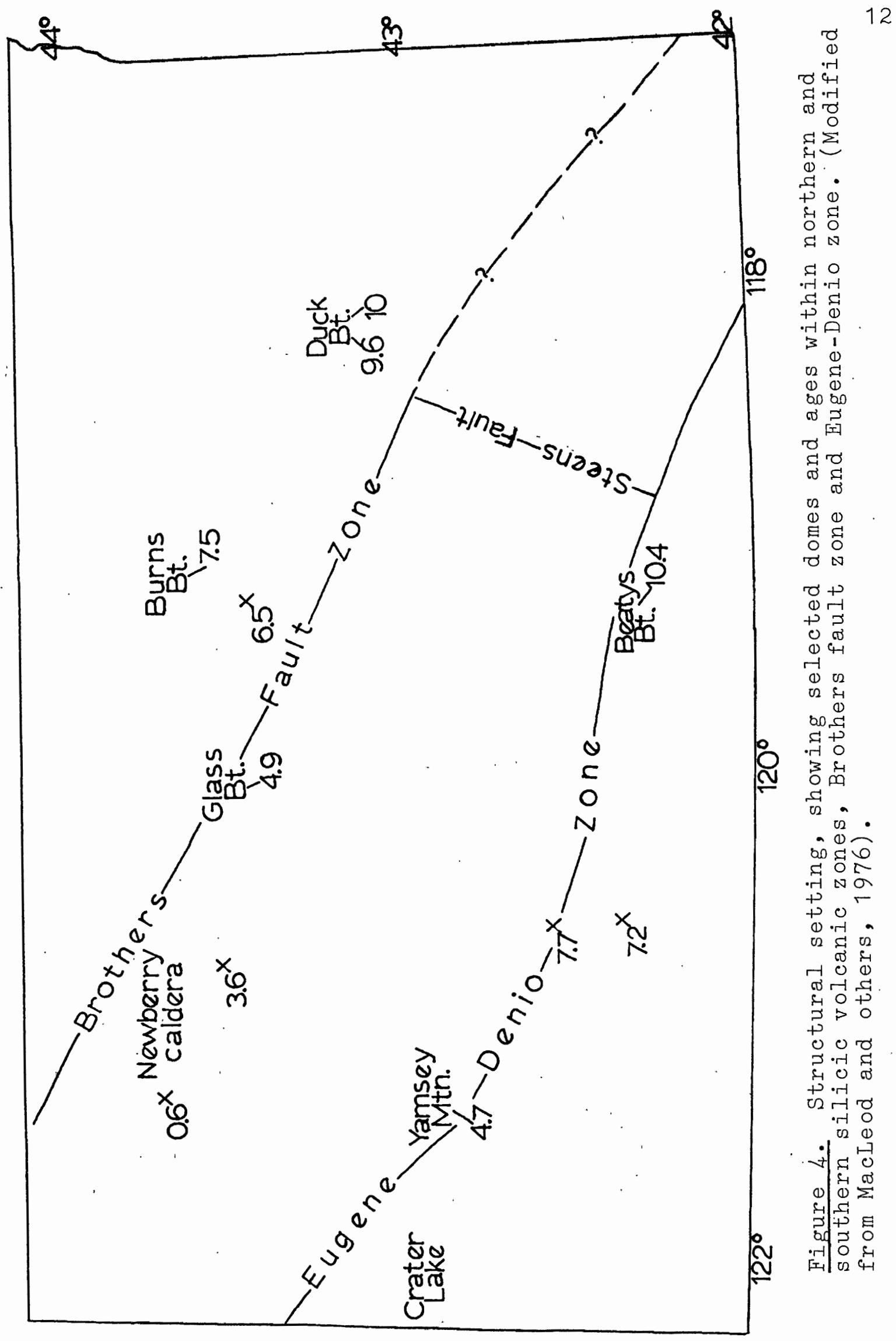


Within the zone are a number of late Cenozoic basalt fields (Walker and Nolf, 1981). A parallel but less well-defined zone of rhyolitic domes exists to the south from Beatys Butte to Yamsey Mountain (Fig. 4; MacLeod and others, 1976). This southern silicic volcanic $z$ one is intersected by the Eugene-Denio lineament zone.

Geologic investigations in the past have not satisfactorily dealt with the origin or possible interplay of the two possibly independent regional structures: 1) the northwest-trending fault and lineament zones, and 2) the westnorthwest-trending zones of silicic volcanic centers. Walker and Nolf (1981) ascribe distribution of vents to the Brothers fault zone, but their interpretation may be too simplistic. The silicic volcanic zones described by MacLeod and others (1976) are not parallel to nearby regional fault zones. Although the degree of parallelism is subject to individual interpretation, certain aspects of the northern silicic zone suggest its independence from the Brothers fault zone, as outlined below.

Using forty-seven $\mathrm{K}-\mathrm{Ar}$ dates on rhyolitic dome rocks of southeast Oregon, MacLeod and others (1976) defined two belts of volcanic centers, each showing a westward decrease in ages (Fig. 4). Domes younger than $5 \mathrm{~m} \cdot \mathrm{y}$. show three significant features: 1) the rate of westward growth of the zone slowed after $5 \mathrm{~m} \cdot \mathrm{y} \cdot$; 2) the volume of materials erupted from the domes decreased, and 3) the orientation of the zone became more northerly. Also significant is that at $5 \mathrm{~m} \cdot \mathrm{y}$. 
the northern silicic zone intersected the Brothers fault zone: domes older than $5 \mathrm{~m} \cdot \mathrm{y}$. lie generally east and north of the fault zone, whereas younger domes lie west and to the south. Glass Buttes, in the vicinity of this structural intersection, has been dated at $4.9 \mathrm{~m} \cdot \mathrm{y}$. (Walker, 1974). These features suggest that the northern silicic volcanic zone developed after formation of the Brothers fault zone and intersected the fault zone about $5 \mathrm{~m} \cdot \mathrm{y}$. The intersection slowed the rate of westward progression and decreased the volume of the dome complexes, as. well as bent the trend of successive domes into closer alignment with the Brothers fault zone. The fault zone shows no change in orientation from one side of the intersection to the other. If the fault zone is the older of the two structures, it has been active at least since $5 \mathrm{~m} \cdot \mathrm{y}$. ago, as well as in more recent times.

A different interpretation may result in considering a larger regional setting. The silicic volcanic zone may signify volcanism occurring through a west-northwest-trending strike-slip fault zone, similar to a transform fault zone adjacent to a mid-ocean ridge spreading center. The westward migration of the volcanic front.implies a north-southtrending spreading center exists near the east end of the zone, near the Oregon-Idaho border. Volcanism east of the proposed spreading center has, in fact, mirrored that occur: ing to the west across Oregon. The Pliocene volcanic rocks 
of the Snake River Plains in Idaho show an eastward decrease of ages and volumes (Walker and MacLeod, 1977).

A change in regional stress orientations occurring about $5 \mathrm{~m} \cdot \mathrm{y}$. ago. may have altered the character and course of the silicic volcanic zone in Oregon. The Brothers fault zone, oblique to the volcanic zone, represents fracturing initiated by a new stress regime. post-dating that of the volcanic zone and still active today.

Further discussion of the Brothers fault zone may be found in Structural Geology. 
STRATIGRAPHY

\section{REGIONAL STRATIGRAPHY}

Western and eastern portions of the High Lava Plains experienced similar styles of volcanism during the late Miocene and Pliocene (Fig. 5). From this it is assumed that Glass Buttes is underlain by lavas correlative with Columbia River Basalt Group and Steens Basalt lavas and that rhyolitic volcanism began around $9 \mathrm{~m} \cdot \mathrm{y}$. ago, but by at least $5 \mathrm{~m} \cdot \mathrm{y} \cdot \mathrm{ago}$.

Reconnaissance geologic maps (Walker and others, 1967; Greene and others, 1972) indicate the late Miocene to Pliocene Glass Buttes silicic rocks are dacitic to rhyolitic lava flows and ash-flow tuffs, with lesser amounts of obsidian and perlitic glass. Tuffs dated at $6.5 \mathrm{~m} \cdot \mathrm{y}$. from the Harney Basin to the east reached neary. as far west as Glass Buttes (Walker, 1979). Explosive volcanic rocks are limited within the eastern Glass Buttes. Late Pliocene diktytaxitic olivine basalts are widespread to the east, northeast and west of Glass Buttes, forming a broad plateau of lava flows.

Tertiary and Quaternary alluvial sediments were observed surrounding the Glass Buttes complex, interfingering with Pliocene plateau basalts, and include lacustrine and fluvial sediments. A large fault-bounded basin to the south 


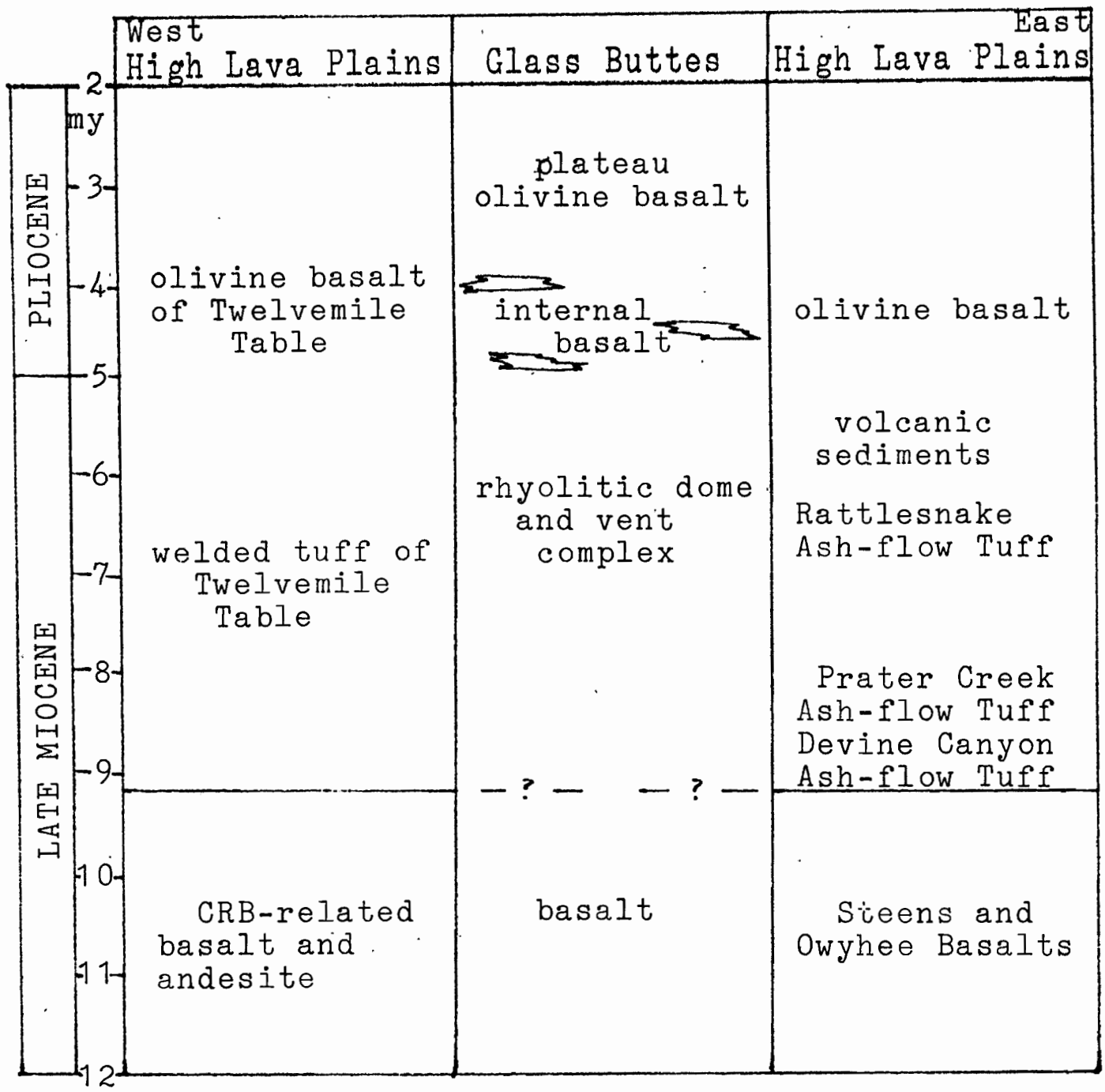

Figure 5. General stratigraphic correlation chart of the High Lava Plains for late Miocene to Pliocene time. (from Greene and others, 1972; Walker, 1979; using time. scale of Lowrie and Alvarez, 1981). 
near the old town of Stauffer, contains Quaternary playa deposits (Walker and others, 1967).

\section{LITHOLOGIC GROUPS AT GLASS BUTTES}

The stratigraphy is complicated by the building of the volcanic complex by successive eruptions of small volume. Only a small proportion of the exposed volcanic rocks are tuffs; most are siliceous lavas which erupted as flows and domes having limited areal extent. The viscous nature of the siliceous flows raises questions about attempted correlation of similar-appearing rhyolites separated by nearly a kilometer across the study area. Exposures of the contacts between these units are rare, so relative age relationships are not definable. Lithologic types, therefore, were mapped. without striving to locate and trace depositional contacts. With the exception of the basalts, all rock units are highly glassy and many are totally composed of glass. The few phenocryst-bearing units are nearly aphyric rhyolite flows, so stratigraphic distinctions based on petrography (e.g. feldspar compositions) are not reliable.

Methods of determining local stratigraphic sequences are as follows: 1) observation of topography. Because the present topographic surfaces do not appear deeply eroded, these surfaces are assumed to represent original flow tops. Thus, elevations of flow surfaces and dips of flow layering suggest possible directions to the source for the flows.

2) Float types provided information about rock underlying 
the soil, as well as indicating the topographically highest occurrence of unexposed units. 3) Data from drill holes placedifimportant constraints on stratigraphic relation,s, especially the extent and to some degree the age of basalt. 4) Eruptive processes (e.g. dome development) were found to form varying volcanic textures and weathering products.

Processes of crystallization of glassy volcanic rocks, as well as development of flow banding, have occurred to varying degrees in the rhyolitic rocks of Glass Buttes. Crystallization is accomplished through devitrification and vapor phase alteration. Natural amorphous glass is unstable under surface conditions and tends to crystallize, or devitrify, to a more crystalline rock generally composed of feldspar and silica with minor pyroxene and iron oxides. This commonly is in the form of spherulites, fibrous radiating intergrowths of cristobalite and sanidine (Williams and others, 1954; Ewart, 1971), 1 to $5 \mathrm{~mm}$ in diameter, with concentric zoning. The polygonal shapes of spherulites usually coalesce, leaving patches of residual glass that eventually devitrify to microcrystalline non-spherulitic aggregates (Ewart, 1971).

The glass contains volatiles in solution, and release of the volatiles upon devitrification forms vesicular cavities. The volatiles, as well as others derived from the cooling flow (e.g. heated groundwater), migrate upward along fractures and flow planes. Crystallization from this vapor phase consists of tridymite and feldspar forming in open 
spaces (Ross and Smith, 1961). Pores may be the vesicular cavities in pumiceous fragments or layers. The resulting lithophysal zone occurs near the top of the flow.

Silicic lavas tend to show development of flow structure in the interior of the flow, arising from differential laminar flowage. This structure is referred to as flow layering, fluidal layering or flow banding. The fluidal layering is commonly contorted and folded at flow edges or on steep slopes, where flow of viscous lavas becomes chaotic and slight differential cooling of layers in the flow causes drag that may detach and shear flow bands. Dips of such flow layers are not, of course, useful as source or stratigraphic indicators.

Float of pumiceous glass overlying outcrops of rhyolite flow has been weathered from frothy flow-top material. Flow-top glass is poorly preserved, suggesting a deep level of erosion into the interior of rhyolite flows. As discussed below, thick deposits of obsidian and pumiceous glass overlying rhyolite flow units may also represent chilled flow-top material, but this relationship could not be directly observed.

The siliceous volcanic units of Glass Buttes described below were mapped by Walker and others (1967) as PliocenePleistocene dacite-rhyolite, and by Greene and others (1972) as upper Miocene-Pliocene rhyolite-rhyodacite. The $4.9 \mathrm{~m} \cdot \mathrm{y}$. obsidian dated by Walker (1974) is believed to be the 
youngest unit in the west part of the study area. Much of the eastern Glass Buttes volcanic complex had, therefore, formed by the early Pliocene.

Characteristics of rock types and units identified in the eastern Glass Buttes are summarized in Table I. For ease of discussion, the silicic volcanic units in the study area will be described in groups related by similar processes of formation. These include 1) lava flows ( $A$ and $B$, Table I), 2) rhyolitic glass and pumice forming exogenous domes ( $C$ and D), 3) rhyolitic glass forming endogenous domes (C), and 4) pyroclastic air-fall deposits (E). Basalt and volcaniclastic sediments are described following the silicic rocks.

\section{Lava Flows}

Units formed by eruption of flows from a vent source include rhyolite and obsidian flows, described separately below. The vent areas for the flows generally lie in the vicinity of blocky jointed outcrops at the crests of these major topographic features. Hillsides slope gently away from these probable vent areas. Crossections $A-A^{\prime}$ and $B-B^{\prime}$ of Plate II illustrate the sequence of rhyolite flows and obsidian. (Plates I and II located in rear pocket.)

Older Rhyolites. Rhyolitic lavas are found on Little Glass Butte and Antelope Ridge (see Fig. 2). Located in the west-central part of the study area, Little Glass Butte is a prominent peak surrounded by low hills. The butte slopes 


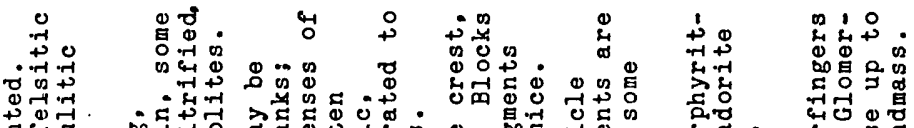

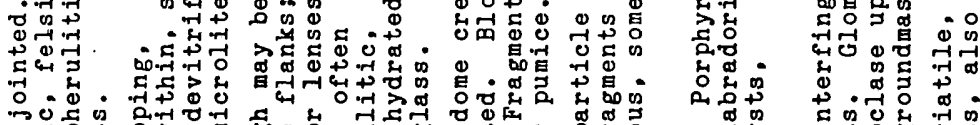

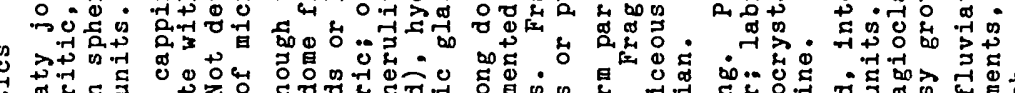

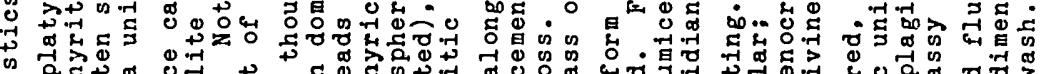

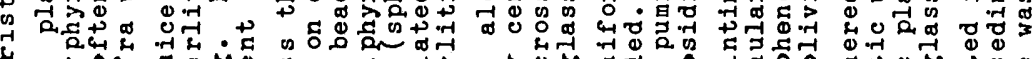
कृ

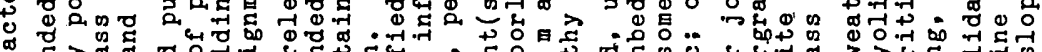

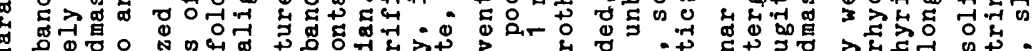

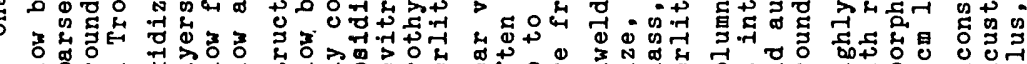

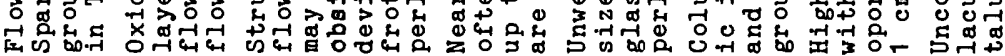

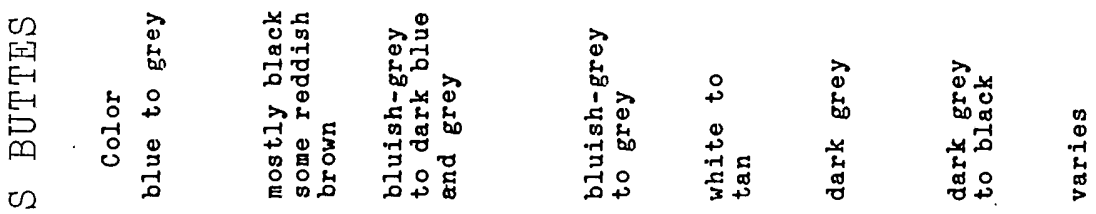

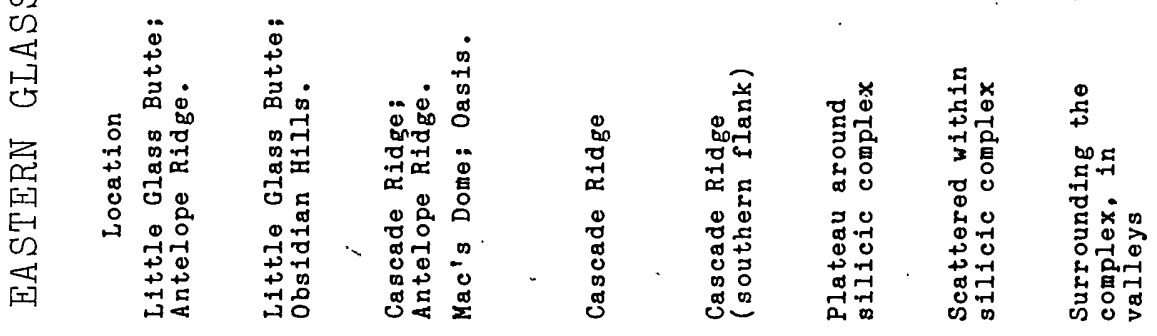

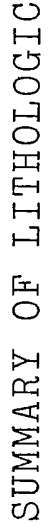

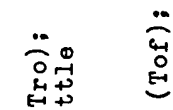

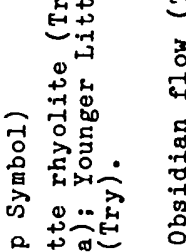

娄总点。

०

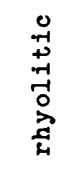

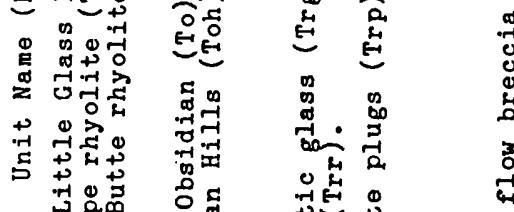

武带苟

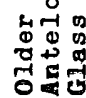

品 出

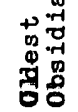

뭉

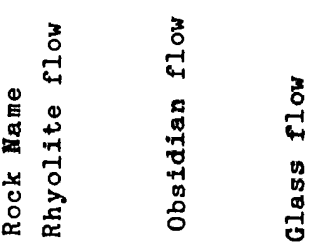
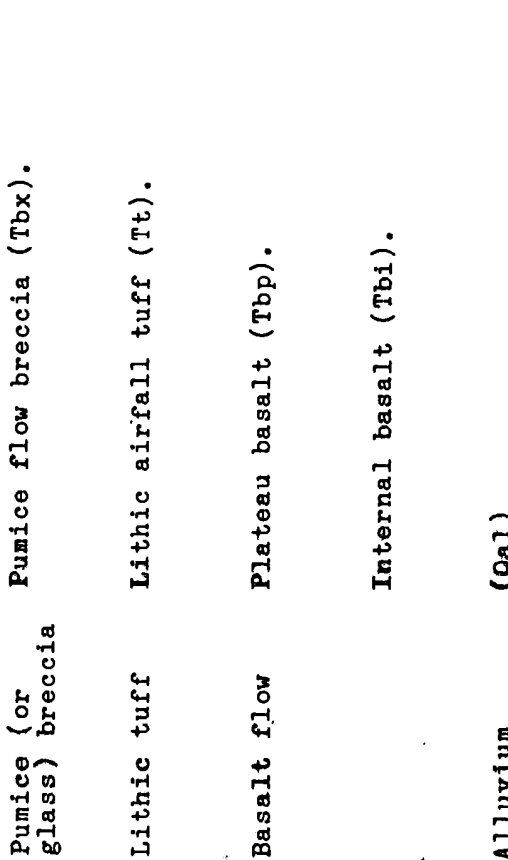
steeply off to the south but more gently to the north, suggesting most lavas flowed down the northern flanks.

Low on the steep southeast side of Little Glass Butte is a blue, finely flow-banded rhyolite (Tro, Plate I) that originated from near the present summit of Little Glass Butte. This is the older of the two Little Glass Butte rhyolite flows, and forms a 5-m high outcrop that trends N1 $10^{\circ}-20^{\circ} \mathrm{W}$ for over $900 \mathrm{~m}$, containing contorted flow banding (Fig. 6) and northwest-trending extensional joints. Flow

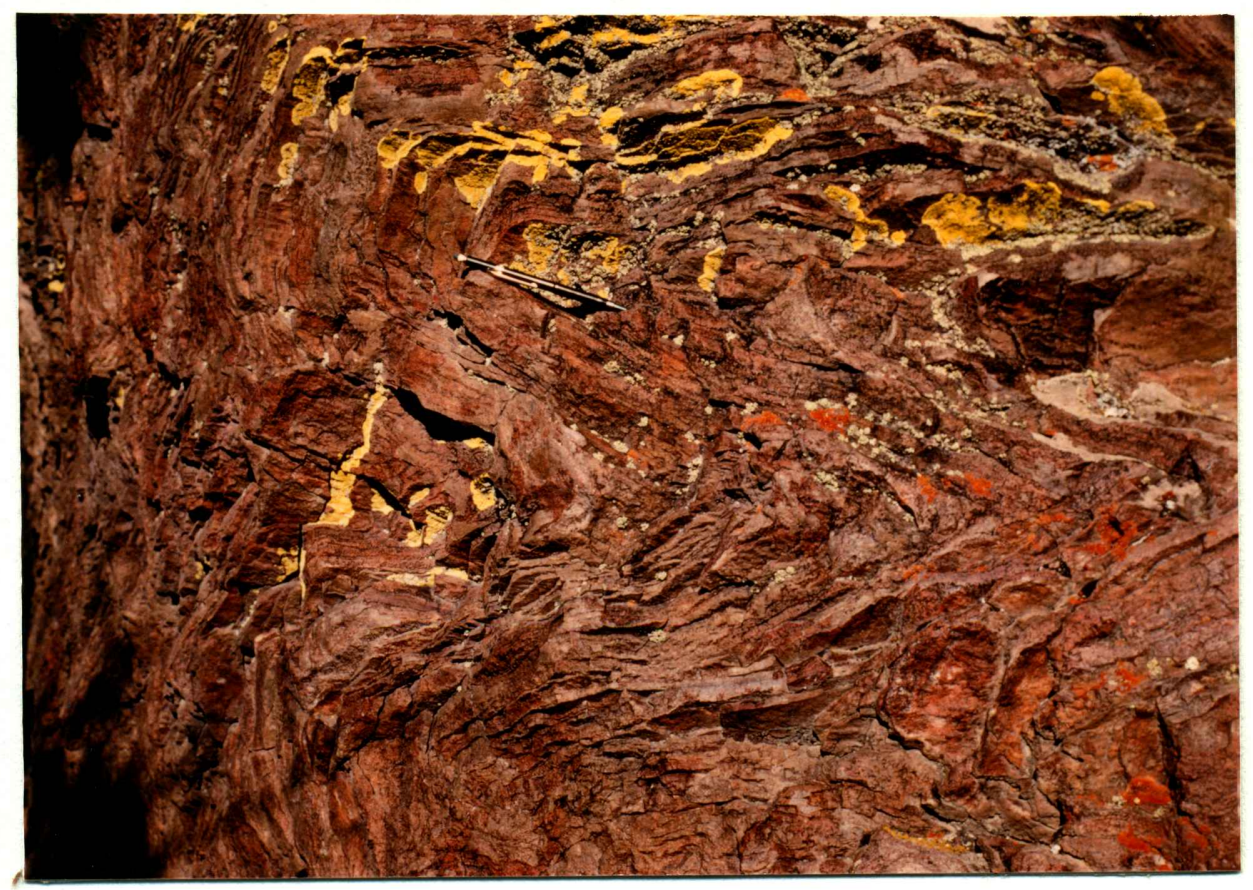

Figure 6. Contorted flow banding. Older Little Glass Butte rhyolite, southeast flank Little Glass Butte. Pencil is $27 \mathrm{~cm}$ long.

bands dip away from the peak; this and the contorted nature of the banding suggest the outcrop may be the edge of a flow. Weathering along pink-colored flow-band surfaces 
results in flaking of layers about $5 \mathrm{~cm}$ thick that produces a platy appearance in outcrop. This rhyolite is also exposed in deeply eroded gullies in the hills to the east of Little Glass Butte.

The older Little Glass Butte rhyolite flow is indistinguishable petrographically from the Antelope rhyolite (Tra, Plate I) found $0.8 \mathrm{~km}$ to the northeast on Antelope Ridge. Due to the viscous nature of these two units, a separate source is proposed for each though the lavas are chemically (see Fig. 18) and petrographically similar.

Natural and unaltered rock outcrops are found in only a few locations on the northwest-trending Antelope Ridge. The blue, finely flow-banded Antelope rhyolite flow originated from near the east peak of the ridge (a nearby topographic high). A massive and irregularly jointed outcrop can be found at the site of a possible vent.

The older Iittle Glass Butte and Antelope rhyolites are composed of devitrified flow-banded glass that is over 90 percent spherulites (Fig. 7). Long wavy parallel threads of isotropic or dark brown glass extend across the section, and are bounded by spherulites; this banded texture represents fractures formed by flowage and shearing during early cooling of the viscous lava, as the banding is often highly contorted and broken. These flow planes became sites for devitrification. Xuray diffraction study of the nearly 


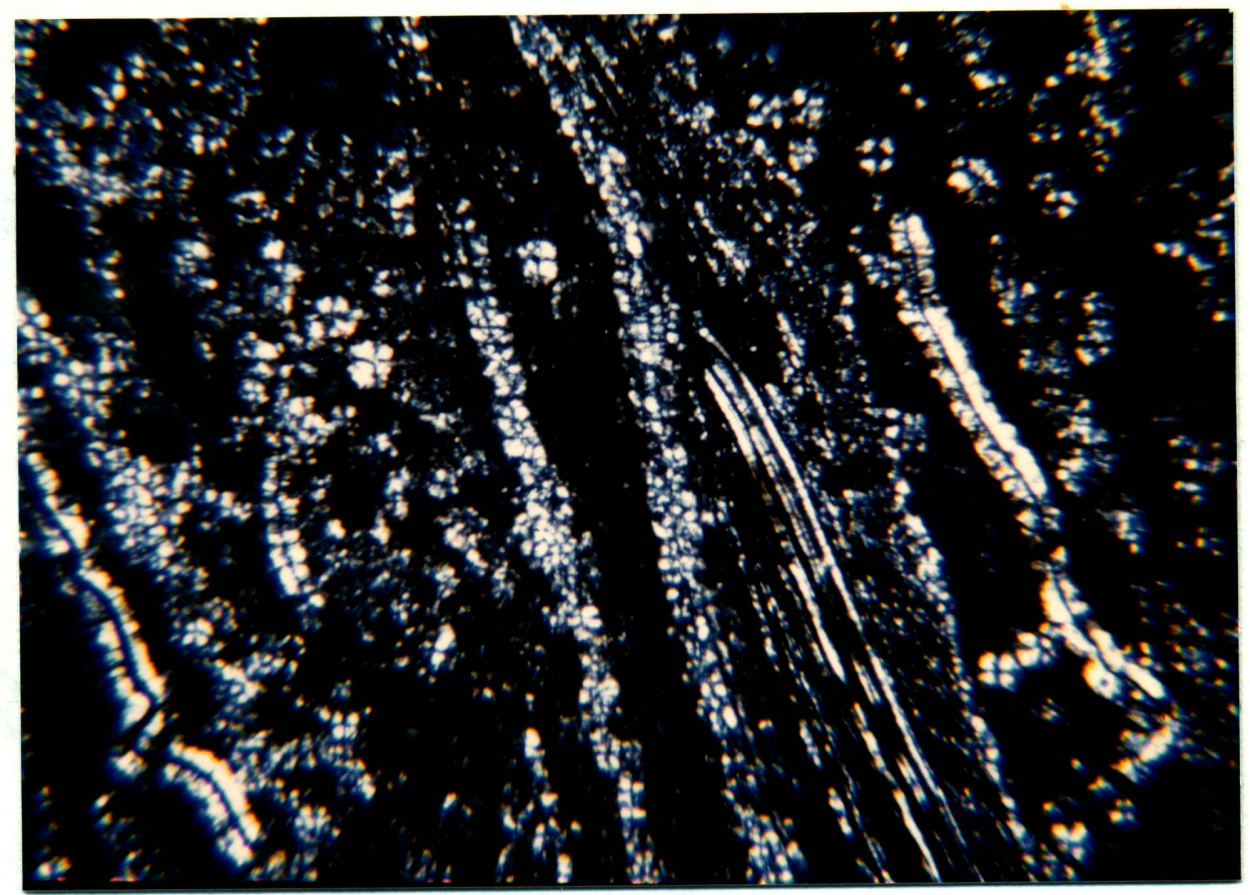

Figure 7. Spherulites, older Little Glass Butte rhyolite. Cross polars, x 2.5 .

aphyric rhyolites indicated cristobalite with feldspar (Fig. 8a-c), probably representing the composition of the spherulites.

The formation of spherulites in the glassy rocks seems characteristic, in contrast to the dense amorphous glass of the younger Little Glass Butte rhyolite; these units are more thoroughly devitrified than the younger rhyolite. X-ray diffraction analyses also show greater crystallinity in the older rhyolites, in which the main constituents are cristobalite and plagioclase (Fig. 8a, b and c). The diffuse or incipient cristobalite "peak", or rise, centered roughly about $4.04 \mathrm{~A}$ or 2220 in Fig. 8d, represents poorer crystallinity (Tatlock, 1966) of the glassy, younger 


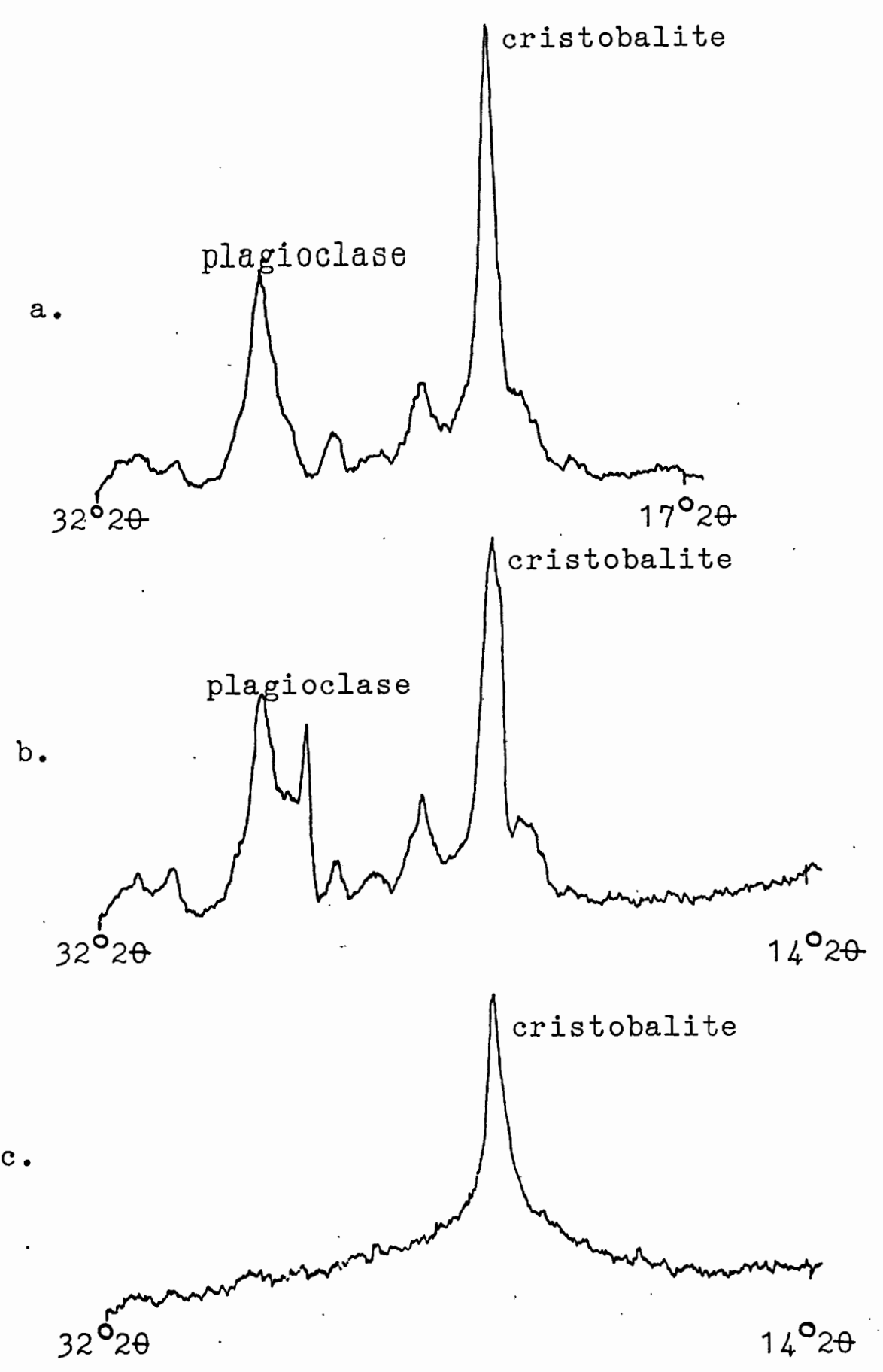

d.

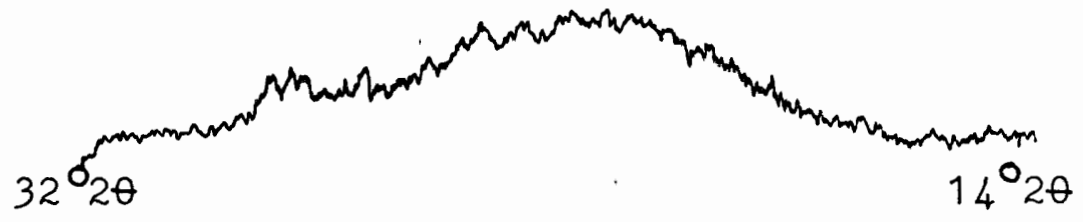

Figure 8. X-ray diffraction patterns, Little Glass Butte rhyolites. a-c. Older rhyolites. b. Younger rhyolite. 
rhyolite. The older rhyolites may have had a higher volatile content, promoting more thorough devitrification. Phenocrysts are commonly glomeroporphyritic and in-.. clide anhedral pyroxene, sanidine, zoned plagioclase microlites $\left(\mathrm{An}_{11-28}\right)$ and corroded quartz. One perthitic feldspar grain was observed. Determination of feldspar compositions was hampered by sparseness and size (Iess than $0.3 \mathrm{~mm}$ ) of untwinned phenocrysts.

Younger Rhyolite. The younger Little Glass Butte rhyolite (Try, Plate I) is a dark grey to black, glassy, flow-banded rhyolite that spread down the northern slopes of the butte and laterally for over $2 \mathrm{~km}$ north-northeast from the vent. The flat summit of Little Glass Butte is underlain by rubbly, dark reddish-brown, low-lying outcrops of rhyolite. Platy jointing occurs along flow layers (Fig. 9), often coincident with weathering lenses of iron oxides and clay that also formed along flow planes.

Several prominent ridges composed of the younger Little Glass Butte rhyolite extend down the west and north slopes of the butte. Two irregularly jointed, bouldery outcrops on the northwest flank form parallel ridges and are separated horizontally by about $75 \mathrm{~m}$ of float-strewn, pumice covered slope. These ridges become isolated, long linear outcrops, trending about $N_{4} 0^{\circ} \mathrm{W}$, that can be traced downhill to the west. They can be connected to fault traces bounding the longitudinal valley across the main butte at the west side of the complex, thus may be fault controlled. 


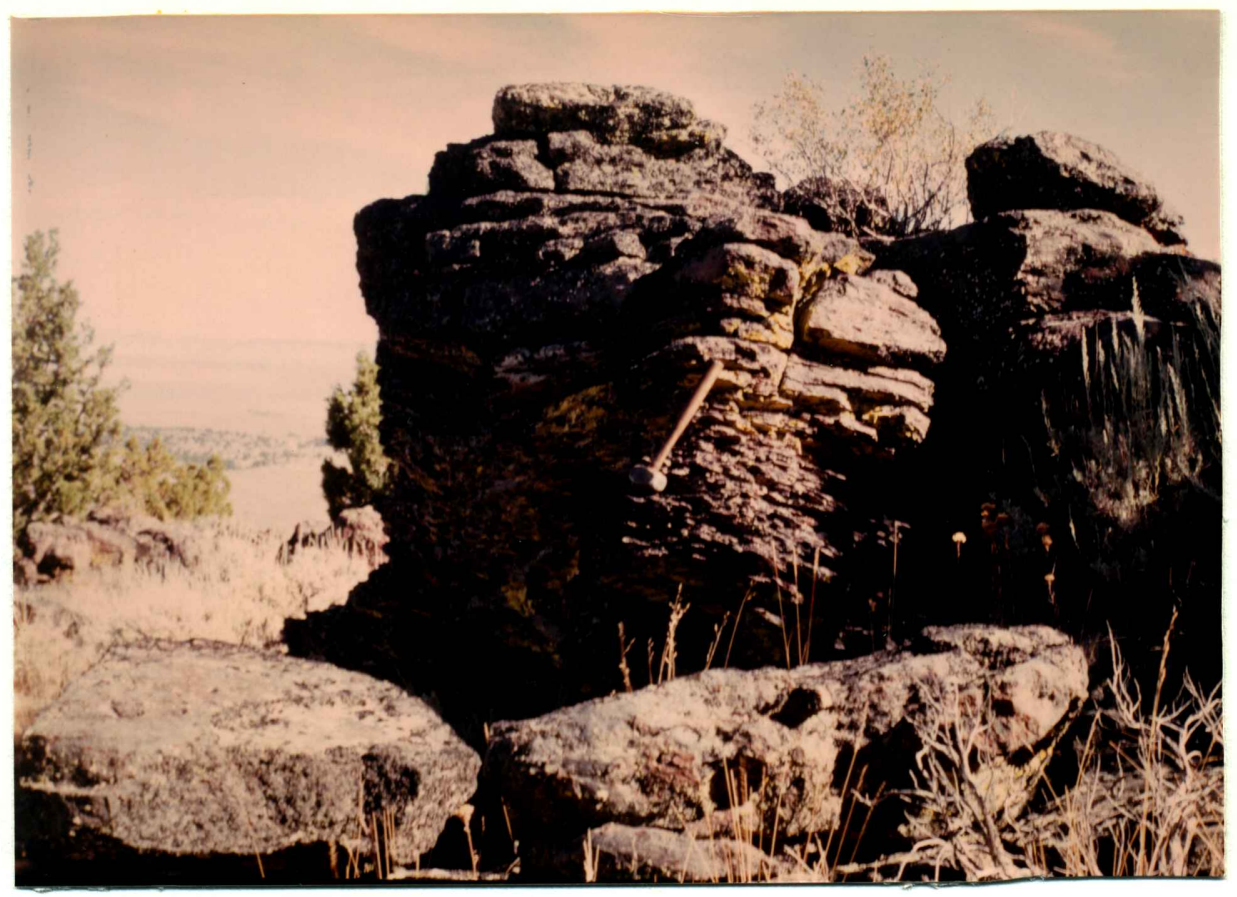

Figure 9. Platy jointing. Younger Little Glass Butte rhyolite, northwest flank Little Glass Butte. Hammer handle is $60 \mathrm{~cm}$ long.

Rattlesnake Ridge (see Fig. 2), on the north slope of Little Glass Butte, is underlain by a series of northwesttrending step-like cliffs of rhyolite, as are low hills farther to the north. The ridge forms the south face of a northwest-trending fault valley about $1 \mathrm{~km}$ wide, bounded on the north by the Obsidian Hills. Weathering along dark red, contorted flow-band surfaces about $5 \mathrm{~cm}$ thick causes large wavy sheets to spall off, forming boulder-sized talus below the north-facing cliffs of the ridge. Similar outcrops with north-facing exposures occur along two northwest-trending faults north of Rattlesnake Ridge (Plate I). The rhyolite, hidden elsewhere by a layer of obsidian and soil, is exposed along these three faults. 
The younger Little Glass Butte rhyolite, like the older rhyolites described previously, is a glassy, sparsely porphyritic lava but generally shows little to no evidence of devitrification in thin section or in X-ray diffraction analyses (see Fig. 8d). Phenocrysts are slightly more abundant than in the older rhyolites, comprising 5 to 10 percent of an otherwise opaque to brown, glassy rock. Euhedral andesine phenocrysts $\left(\mathrm{An}_{45}\right)$ are albite-twinned and commonly zoned. Rounded and fractured pyroxene heavily included with iron oxides, as well as small, unidentified phenocrysts of feldspar, are also present.

Obsidian. Black rhyolitic glass, or obsidian, is ubiquitous in the west half of the study area, especially north and east of Little Glass Butte. Outcrops are nonresistant and thus usually evident only as float that characteristically forms anastomosing talus streams on hillsides. Scattered excavations by rock collectors have exposed obsidian beneath the soil.

On the basis of topographic character and its indication of relative ages, three separate obsidian units were mapped around Little Glass Butte and Obsidian Hills to the north. These units are not, however, separable on the basis of hand sample appearance alone. Further chemical work may correlate them with underlying rhyolite flows but because of their thicknesses, $1 \mathrm{~m}$ or more, the obsidian is not believed to simply represent the glassy selvage of the underlying rhyolite flow, and therefore is treated as a separate unit. 
The distribution of the obsidian is related to obsidian flows, capped by a pumiceous, frothy and oxidized glass (Fig. 10). Hydration and oxidation of this rind may have

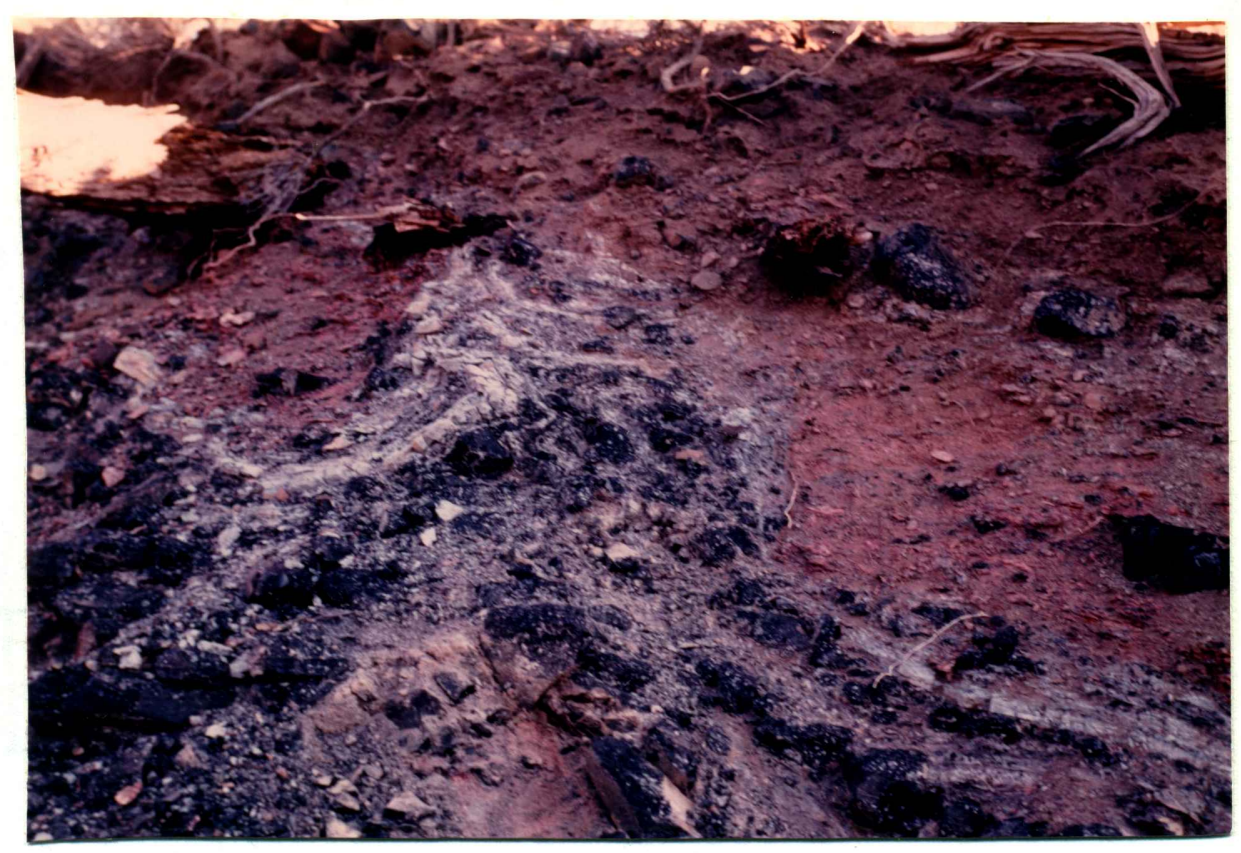

Figure 10. Obsidian outcrop; east lobe, Obsidian flow southeast of Little Glass Butte.

been caused by escaping gases or heated groundwater circulating through the cooling lava (Noble, 1967). Hydration produces thin layers of grey perlite within which may be found rounded remnants of the original black obsidian (Fig. 10). The total lack of devitrification of the obsidian implies low content of volatiles in the lavas upon eruption.

The obsidian is highly variable in color, from dense black glass, black glassy shards in a red-brown matrix, thin black and red banded glass, to nearly pure reddish-brown 
glass (Fig. 11). A study of this type of Glass Buttes obsidian by Fuller (reprinted in Waters, 1927a) concluded that the varied colors are due to oxidation of iron during flow of the viscous obsidian, and mixing of this red glass with unoxidized black fragments. Fusion may have further changed the red and black glass to the point of intimate, microscopic mixtures.

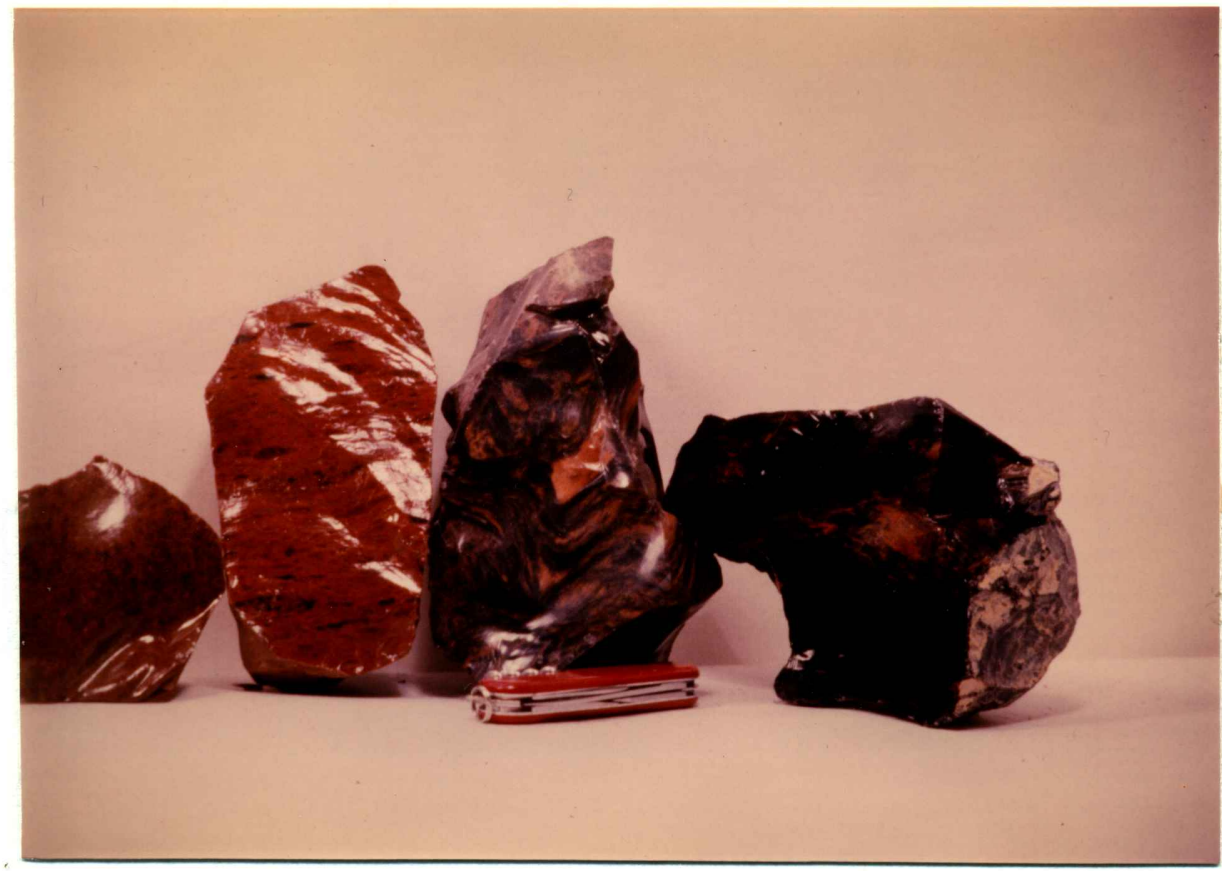

Figure 11. Obsidian varieties. From left to right: red-brown, red-brown breccia, red and black banded, and black with red lenses.

Low on the west and southwest flanks of Little Glass Butte, surface float is primarily angular obsidian. An excavation northwest of the butte exposed nearly $1 \mathrm{~m}$ of black obsidian with perlite and oxidized glass layers. The base of the obsidian was not exposed. This obsidian (To, 
Plate I) appears topographically and spatially distinct from the obsidian flow described below, as well as from the Obsidian Hills north of Little Glass Butte, and is considered the oldest obsidian. It underlies both of the Little Glass Butte rhyolite flows and the obsidian flow and its vent may be near Little Glass Butte.

A distinct multiple-lobed flow of obsidian southeast of Little Glass Butte (Tof, Plate I) probably originated from the east side of the butte. Several thick exposures were found in this area of massive black obsidian with reddish-orange frothy glass cappings. The obsidian flowed south-southeast over and around the older Little Glass Butte rhyolite. Although no vent was located, it is presumed to be under the younger Little Glass Butte rhyolite, which may have issued from the same vent but flowed to the north. Obsidian forms rolling hills north of Little Glass Butte (Toh, Plate I). It overlies the younger Little Glass Butte rhyolite, and so is the youngest of the obsidian units. This may be the obsidian dated by Walker (1974) at $4.9 \mathrm{~m} \cdot \mathrm{y}$. Possible sources lie within the Obsidian Hills area, for example the prominence $800 \mathrm{~m}$ southeast of Midnight Point, or Mac's Dome, as well as the area of Little Glass Butte. As discussed earlier, the obsidian may also be part of a glass and pumice carapace capping a rhyolite flow. 
Exogenous Domes

Domes with primarily exogenous character form by eruption of viscous lavas from a summit vent. The glassy carapace is repeatedly fractured by upwelling magma, and is often covered with pumice blocks and spines of lava. Wellknown domes of this type include Lassen Peak and Mono Craters in California. Domes of the Coso Range, California, have recently been well documented by geothermal investigators (Duffield and others, 1980; Bacon and Duffield, 1980; Roquemore, 1980; Bacon, 1982).

In Oregon, the west-northwest-trending belt of volcanic vent and dome complexes described by MacLeod and others (1976) consists of exogenous domes of rhyolite and obsidian flows and flow breccia, that are commonly elongated subparallel to the trend of the volcanic belt. Glass Buttes contains many exogenous domes throughout the complex. Variations in dome rocks are best illustrated by a small dome west of Little Glass Butte (see Fig. 2), described below. This dome served as a model for development of other exogenous domes in the Glass Buttes area.

The dome is elongated approximately west-northwest, and lies on a west-trending structural lineament that ex- is tends west through Glass Butte and to the east along the south flank of Little Glass Butte. Glass flows found in outcrops low on the flanks of this dome are flow-banded. The flow banding dips steeply downslope and locally is folded and overturned. Infrequent lenses of obsidian up to 
$4 \mathrm{~cm}$ thick occur between flow layers. Nearer the ridge crest, the glass is more vesicular and frothy, and contains flow layers of gentler dip. The dip of such banding is generally towards the center of the dome.

Littering the top of the dome are fragments from a glass breccia. Rarely found as consolidated rock, pieces of the breccia more often occur as fragments or rounded cobbles of frothy glass averaging $10 \mathrm{~cm}$ long, covering the ground. This matrix-free breccia could have formed by surface autobrecciation of erupting glass flows, by subsurface brecciation before eruption (Williams and McBirney, 1979), or by fracturing of the carapace glass. Breccia fragments are oxidized to a light orangish-brown color. Fine, rounded obsidian float, weathered out of glass, is also found here.

Evidence of lithophysal development was observed at the crest of the dome as well as at the nose of the flanking flows where flow interiors are exposed, and is due to crystallization from gases escaping from the dome. At the nose of the flows, these lithophysae are filled or lined with undetermined secondary minerals. A similar lithophysal zone occurs at the crest of the dome, crosscuts flow banding and has a vertical contact with surrounding flow-banded, nonlithophysal glass. A fracture may have opened here, allowing gases from deep within the dome to permeate vesicular glass in the vicinity of the fracture. 
Recognition of dome-related rock types, including flow-banded glass, frothy glass, frothy glass breccia and lithophysal glass aided in interpreting partial assemblages of dome rocks found elsewhere in the area.

Cascade Ridge is an area of dome building. Sequences of volcanic materiáls observed here are similar to the pattern described previously for the small dome west of Little Glass Butte. The ridge trends $\mathrm{N} 65^{\circ} \mathrm{W}$ for nearly $3 \mathrm{~km}$ and rises to a high point of nearly $1700 \mathrm{~m}$ at its east end. From the south, gullied slopes rise gradually to the ridge crest and are characterized by sparse rock outcrops. Several trenches related to mercury mining activity are present on the south side. The north-facing slopes, in contrast, are steep and smooth and lack natural rock exposures. On the basis of topographic expression, the ridge is believed to be bounded on its north side by a northwest-trending fault (Fig. 12), active after the dome developed.

The southwest and southeast flanks of Cascade Ridge contain south-dipping, blue-grey glass. Upslope at the ridge crest is a pumice breccia containing fragments up to $1 \mathrm{~m}$ long, that has in places been silicified and/or altered by fumarolic activity (see Fig. 23).

\section{Endogenous Domes}

Domes with mostly endogenous character form by expansion from within, by internal doming, with little eruption of viscous lavas. The two small domes described below are 


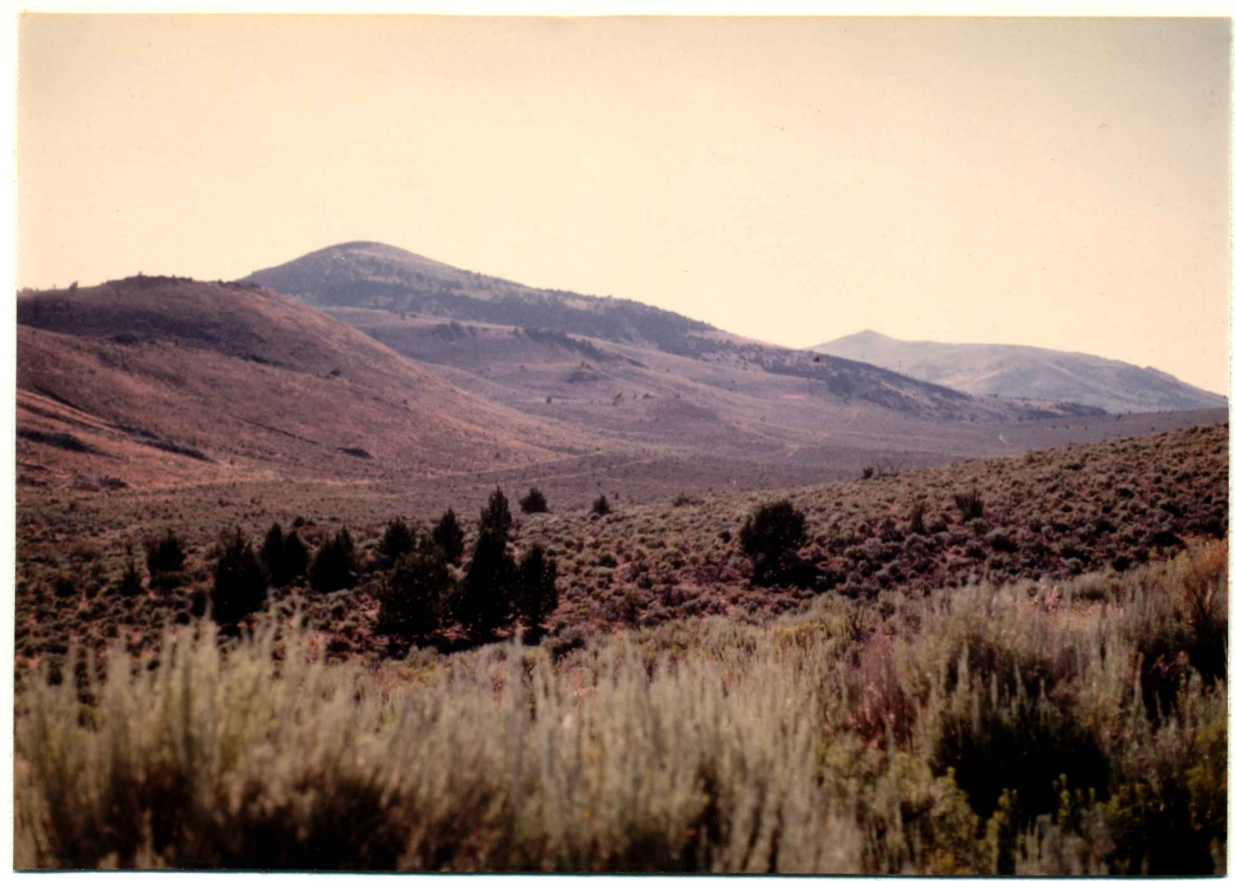

Figure 12. Cascade Ridge fault valley, looking southwest down central valley: Cascade Ridge at left, Little Glass Butte left of center, and Glass Butte right of center in distance.

circular mounds distinct from other topographic features, from which thick glassy lava flowed only short distances. Mac's Dome is located about $3 \mathrm{~km}$ north of Little Glass Butte on an obsidian-covered hillside, and along the trend of the Cascade Ridge fault. This small, circular plug is about $150 \mathrm{~m}$ in diameter, and consists of crudely jointed, dense, grey glass. Toward the west side of the dome is a small spine, composed of blocks of light blue, vesicular glass piled up to a height of over $12 \mathrm{~m}$, that contains lenses of obsidian beads. The material in the spine is generally more inflated and perlitic than that found elsewhere on the dome. 
The Oasis is a circular rise from the alluvial valley at the west end of Cascade Ridge, also on the Cascade Ridge fault trend. The area is vegetated with dense juniper and thick, unusually tall (1 to $2 \mathrm{~m}$ high) sage bushes, providing shade for cattle. Hydrothermal alteration associated with extrusion may have formed a clayey surface layer with greater-than-normal water-holding capacity, thus supporting the lush vegetation. Several outcrops of red oxidationcoated, dense grey glass are found on the dome. Breadcrust cooling surface textures are common, as are very thin fracture coatings of hyalite (clear, amorphous silica). No extremely vesicular outcrops were observed, thus extruded material may have had a lower water content than the perlitic glass of Mac's Dome.

Pyroclastic Air-fall Deposits

A single tuff unit crops out south of Cascade Ridge, lining a broad, east-west-trending drainage. The lithic tuff weathers to form a white, ashy soil. Exposures up to 2 m thick show moderate sorting of dark and light blue glass, obsidian, glass containing obsidian beads, and pumiceous glass. Fragments of dense glass are up to $15 \mathrm{~cm}$ long, while frothy glass is generally about $2 \mathrm{~cm}$ in size. The tuff is well indurated but not welded. No bedding or size gradation was observed. Because of the tuff's nearly uniform particle size, it is believed to be an air-fall tuff rather than having originated from a pyroclastic flow. 
Crossection C-C' (Plate II) shows the position of this tuff overlying obsidian and rhyolite units south of Cascade Ridge.

\section{Baisalt}

Two distinctively different types of basalt occur in the eastern part of Glass Buttes. Plateau basalts are finegrained, vesicular lavas that lap onto the silicic volcanic complex. Internal basalts are coarsely porphyritic lavas of limited extent, believed to have erupted. from vents within the dome complex.

The voluminous fine-grained, dark grey, porphyritic plateau basalts (Tbp, Plate I) lap onto the Glass Buttes complex (Plate II) and form the extensive surrounding plateau. Crossection B-B' (Plate II) shows an incursion of plateau basalt into the buttes. At this location, plateau basalt is over $90 \mathrm{~m}$ higher in elevation than the surrounding plateau, uplifted by a northwest-trending fault that extends across the Obsidian Hills (Plate I).

Plateau basalt flows are exposed in outcrops of 2 to $6 \mathrm{~m}$ in height along intermittent stream channels. Moderate to highly vesicular outcrops suggest exposures may represent flow tops, but total thickness is unknown. Weathering to a dark red-brown color, outcrops have rubbly bases and usually are overlain by less than $30 \mathrm{~cm}$ of fine soil.

Stratigraphic test holes numbers 2 and 3 are located north and northeast of Antelope Ridge, respectively (for locations, see Fig. 2; for lithologic logs, see.Fig. 28). 
Neither drill hole intersected basalt. Instead, alluvial material similar to that found in Test hole no. 1 (within the central valley) suggests a thick pile of volcanic sedimentary debris derived from Glass Buttes accumulated before the eruption of the plateau basalts and formed a partial barrier to the onlapping basalt flows. An apron of alluvium today obscures the contact of basalt with rhyolitic units (Plate II).

The fine-grained, dark grey to black, plateau basalt has a sub-porphyritic, intergranular texture with 24 percent plagioclase and 20 percent pyroxene phenocrysts in a groundmass of plagioclase microlites $\left(\mathrm{An}_{50}\right)$, pyroxene, olivine, iron oxide and glass (Fig. 13). Plagioclase grains

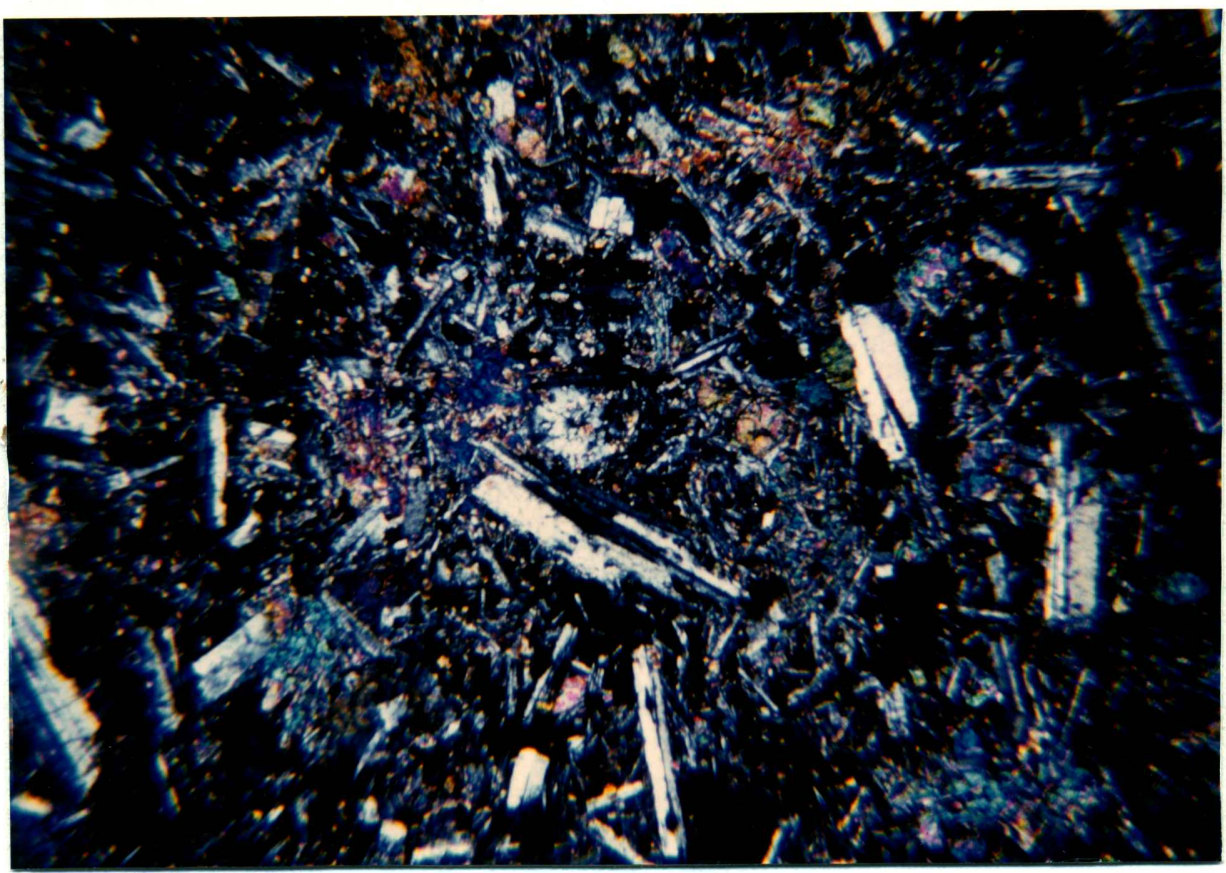

Figure 13. Plateau basalt, photomicrograph, crossed 
occur in a wide range of sizes from 0.2 to $0.7 \mathrm{~mm}$ long. The larger plagioclase grains $\left(\mathrm{An}_{54}\right)$ are subhedral laths averaging $0.7 \mathrm{~mm}$ long, occasionally containing inclusions of bleb-shaped pyroxene and iron oxides along twin planes. Subhedral augite grains are ophitic to poikilitic, having developed after formation of much of the plagioclase. The groundmass contains anhedral olivine weakly altered to iddingsite, pyroxene, and plagioclase laths. Minor groundmass constituents are included in the modal analysis below.

$\begin{array}{llr}\text { Phenocrysts: } & \text { plagioclase }\left(A n_{54}\right) & 24.1 . \% \\ \text { Groundmass: } & \text { augite } & 20.7 \\ & \text { plagioclase }\left(\mathrm{An}_{50}\right) & 17.4 \\ & \text { vesicles } & 13.1 \\ & \text { olivine } & 8.1 \\ & \text { glass } & 7.1 \\ & \text { pyroxene } & 4.9 \\ & \text { iron oxides } & 4.6 \\ & & 100.0 \%\end{array}$

(Based on a total of 1000 points counted.)

The plateau basalts are similar microscopically to equivalent Pliocene lavas of southeast Oregon described by Greene and others (1972).

Internal-type basalt ( $\mathrm{Tib}$, Plate I) occurs west of Little Glass Butte, where porphyritic basalt, rich in plagioclase phenocrysts, appears to lap onto the rolling, east flanks of Glass Butte, and may be overlain by the small dome described above, to the south (Plate I). Basalt flows can not be traced out of this area, thus a vent must have existed within the buttes for this small body of basalt. 
The highly feldspathic internal basalt contains glomeroporphyritic plagioclase phenocrysts up to $1 \mathrm{~cm}$ long in a dense, very fine-grained groundmass. Outcrops are highly weathered and difficult to sample. Outcrops west of Little Glass Butte are 4 to $6 \mathrm{~m}$ high and correspond to northeast and west-trending lineaments in the area. Vesicles in the basalt are often lined with light green clayey material, possibly nontronite (Williams and others, 1954). Hyalite was found coating some fractures.

While relative ages of the plateau and internal basalt types could not be determined, further work might show that the internal basalt, suggested by Waters (1927a) to predate silicic volcanism, represents vents reactivated during eruption of the plateau basalts, which may be the youngest unit in the area. It is more likely, however, that these internal basalts, in places interfingering with rhyolite, are part of the bimodal eruptions that formed Glass Buttes. This possibility requires further study.

Volcaniclastic Sediments

Sedimentary materials are widespread in the area and occur as thick valley-fill and low hills that slope down from the buttes to the plateau. These unlithified sediments generally include rounded fragments of obsidian, pumice and perlite in a matrix of light brown, clayey soil, or, as Waters (1927a) termed the unit, "pumiceous sand". Rounded obsidian float is commonly over $15 \mathrm{~cm}$ in diameter, and one 
boulder unearthed by rock collectors was nearly $1: \mathrm{m}$ in diameter. This larger float probably is not far from its source; excavations show a thick weathering zone atop obsidian flows that contains similar loose blocks.

These young sedimentary units formed primarily by fluvial deposition, sheet wash, and talus composed of material eroded from the developing silicic volcanic complex.

\section{SUMMARY OF STRATIGRAPHY}

Stratigraphic relationships are largely based on topography, float type, and drill hole data. Because units continuous over large areas and definite depositional contacts are lacking, stratigraphic relations are apparent only in small areas and relations between units in the west and east portions of the study area are unknown.

Following deposition of late Miocene basalts, equivalent to the Columbia River Basalt Group and Steens basalts, which are not known to be exposed in the Glass Buttes area, vent and dome-related rhyolitic lavas, glass flows and ash erupted from Antelope Ridge-Cascade Ridge vents. The Little Glass Butte rhyolites flowed out to the north and east of the butte, probably at about the same time as eruptions to the east. Stratigraphic relations with the rhyolite and pumice flows occurring to the east are not known.

The older Little Glass Butte rhyolite overlies obsidian, and is topographically lower than the younger rhyolite, which is in turn overlain by a possibly separate obsidian 
unit north of Little Glass Butte. The two rhyolite flows are separated by obsidian occurring east and southeast of Little Glass Buttes. Evidence of a vent for the latter obsidian is lacking, but probably has been covered by the younger rhyolite.

The process of dome development occurred repeatedly in the Glass Buttes complex. The blue to grey glass of Cascade Ridge is topographically lower than a glass breccia that can be found along the dome crest. Two or more vents are postulated for Cascade Ridge and each presumably had a similar pattern of development. Detailed examination of the many small hills within the buttes might reveal as many separate domes.

The plateau basalt may post-date silicic units in the eastern Glass Buttes. The internal basalt, believed by Waters (1927a) to have preeeded silicic volcanism, instead erupted during and perhaps after the rhyolitic lavas. While the basalt west of Little Glass Butte overlies rhyolitic rocks to the west, it underlies the small, glassy dome to the south. A better understanding of the internal basalt would come from isotopic age determinations or further drilling.

Waters (1927a) described field aspects of rhyolitic rocks that he observed on the west butte that are similar to those found in the east Glass Buttes, including a striking banded appearance to the lavas that becomes very contorted toward the flow top. Lacking chemical analyses, he named 
sparsely porphyritic rocks dacites and andesites, as one might easily have named the glassy, dark bluish-grey rhyolites found in the eastern buttes.

Waters described obsidian and pumice capping a "dacite" flow, and obsidian blocks within perlite, as have been found to the east. He apparently overlooked a young-looking lobe of obsidian that flowed out the west side of Glass Butte, covering several square kilometers.

The style of volcanism was, therefore, similar throughout Glass Buttes. Hydrothermal alteration has been exposed at the surface only in the eastern buttes; if alteration exists in the western buttes, it lies at levels deeper than erosion has reached today. 


\section{PETROGENESIS}

The Glass Buttes complex was formed by eruption of rhyolitic and basaltic materials from individual vents or complex domes having overlapping flows. Eruptions occurred along northwest-trending structural weaknesses associated with the Brothers fault zone and the silicic volcanic zone, that provided conduits for rapid eruption of glassy rhyolitic lavas.

Exogenous domes are elongated along the zones of weakness, or faults, and produced viscous glass flows. This glass became inflated by vesiculation and de-gassing that occurred during eruption and cooling of the flow.

Inflation results in expansion of the volume of glass, which cracks under the tension. Spherulitic or perlitic textures are the result. On a larger scale, the volume increase would serve to inflate the domes from within, and suggests many domes at Glass Buttes have an endogenous nature of formation, for at least part of their development.

Dome-related grey, perlitic glass often contains obsidian lenses or pockets up to $15 \mathrm{~cm}$ thick, or finer stringers of obsidian beads. Mayo (1944) suggested the grey glass is actually obsidian that has been remelted by heat from an overlying flow, but gradation of grey glass downward into obsidian was not observed at Glass Buttes. Segmenting and 
stretching as well as folding of these obsidian lenses does, however, suggest they behaved as plastic slip surfaces during movement of the grey glass flow.

It is believed the obsidian and grey glass are genetically related. Obsidian lenses are uninflated, undevitrified portions of the glass flow, representing planes of reheating and remelting of glass, or more likely, glass that was insulated from gases. Weak flow planes, along which hot exsolving gases stream, are sites for early devitrification, which has not occurred in the obsidian lenses.

Other silicic lavas at Glass Buttes formed individual vents, and may have been derived from less volatile-rich magmas, e.g. the Little Glass Butte-Antelope rhyolites and the obsidian flows. Only thin bands of grey, perlitic glass occur in these units, commonly near flow tops and oxidized zones, and reflect lower volatile contents producing less inflated glass than found in dome-related flows. It is not known if they represent lavas from a different magma or. level of a magma reservoir, than that of the domes. Their differing volatile contents could result from deep circulation of groundwater, contaminating only certain parts of the magma reservoir underlying Glass Buttes, but no evidence has been obtained to support this possibility.

Intersection of regional fracture systems at Glass Buttes facilitated the eruption of primarily viscous rhyolitic lavas. Roof rocks over the magma were weak or discontinuous, therefore pressure was never built up within and 
only minor explosive eruptions occurred. Periodic deep faulting may have defused the system, repressing migration of the reservoir to shallow depths, as suggested by Bacon (1982) for the Coso bimodal volcanic field.

A generally-accepted model for bimodal volcanism is lacking. Further investigations are required before the basalts and rhyolites of Glass Buttes can be genetically related, and is beyond the scope of this study. If they prove to be unrelated, models for generation of independent basaltic and rhyolitic magmas may then be tested. 
STRUCTURAL GEOLOGY

\section{LOCAL STRUCTURES}

\section{Lineaments}

Aerial photographs of Glass Buttes indicate abundant linear features (Fig. 14). The lineaments are defined on photographs by vegetation changes, stream channels and shadows. In many cases, lineaments are fault scarps that are continuous for over $3 \mathrm{~km}$ across the barren plateau. The scarps trend $\mathrm{N} 50^{\circ} \mathrm{W}$ in the vicinity of the eastern Glass Buttes but may be of variable trend from $N 5^{\circ} \mathrm{W}$ to $N 75^{\circ} \mathrm{W}$ locally, producing a sinuous pattern in the scarps. Northeast-trending lineaments are much less frequent.

Within the eastern Glass Buttes, two major linear features are evident. The first trends $\mathrm{N}_{4} 0^{\circ}-50^{\circ} \mathrm{W}$ and lies along Antelope Ridge and may be traced across the low, obsidian-covered hills to the northwest. This trend is subparallel to the strike of the main scarps noted in the plateau basalts surrounding the buttes. A second welldeveloped feature parallels Cascade Ridge. It trends about $\mathrm{N} 65^{\circ} \mathrm{W}$, and, in the vicinity of Little Glass Butte, changes to a trend of $N 35^{\circ} \mathrm{W}$, a pattern that is similar to the trend of scarps in basalt on the plateau. North and northeasttrending lineaments visible on aerial photographs may be 


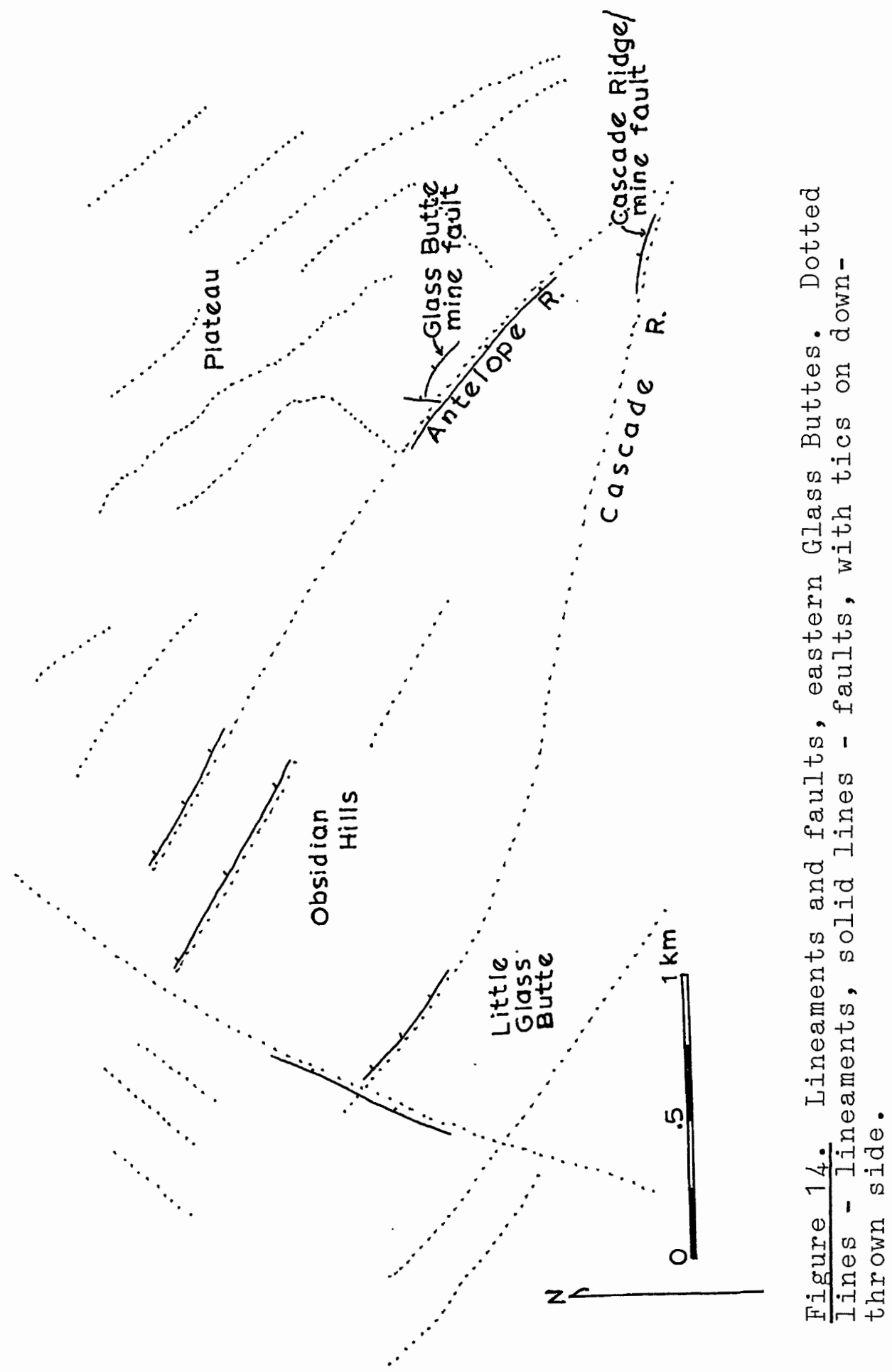


directly fault-controlled, or may be the result of erosional channels trending perpendicular to structural trends.

Failts

The youthful Glass Buttes topography shows many scarps in rhyolite that are believed to be fault scarps despite lack of field observation of grooves, slickensides or fault gouge (Fig. 14). The locations of faults in the east Glass Buttes were, in fact, inferred in nearly all cases from topographic character, and supported. by loci of hydrothermal alteration and/or linear scarp trends that parallelled regional structure.

Displacement on the faults is probably moderate to small. Step-like fault scarps on the north flank of Little Glass Butte average about $5 \mathrm{~m}$ in height, and faults in the plateau basalt expose cliffs up to $10 \mathrm{~m}$ high in the vicinity of Glass Buttes. Plateau basalt that flowed into the eastern buttes has been fault-displaced about $90 \mathrm{~m}$. Walker and Nolf (1981) state that vertical displacements on the Brothers fault zone have generally been from 10 to $100 \mathrm{~m}$. Fault displacement at Glass Buttes probably falls in this range.

The Cascade Ridge fault is exposed at the Cascade mine, southeast Cascade Ridge (Fig. 14). The near-vertical scarp trends $160^{\circ}-70^{\circ} \mathrm{W}$, curving slightly north-northwest at the east edge of the exposure. The fault surface is a resistant, opalite-cemented breccia, and the footwall is silicified. Horizontal ridges about $30 \mathrm{~cm}$ wide appear high on the scarp 
(see Fig. 24). While slickensides were lacking, these ridges imply horizontal strike-slip motion on this curving fault.

The Glass Butte mine fault (Fig. 14) is a similarly curving, north-dipping fault with an opalite-breccia surface and silicified footwall. Neither slickensides nor horizontal ridges were observed here. Another fault on Antelope Ridge is north-trending, east-dipping, and displaces opalite against unaltered glass, thus post-dates alteration (see Structure Related to Alteration).

The Antelope Ridge and Cascade Ridge-Little Glass Butte lineaments described above are believed to represent extensions of the Glass Butte mine fault and Cascade Ridge fault, respectively.

The valley between Antelope Ridge and Cascade Ridge suggests either a large amount of vertical displacement on the Cascade Ridge fault, or a wide separation of the original Cascade and Antelope volcanic centers that was accented by the Cascade Ridge fault. The location of these eruptive centers may have been controlled by structures that represented zones of weakness during development of the buttes and the present trends of Antelope and Cascade Ridges reflect these structures. Continued activity along these faults further dropped the central valley within the eastern buttes, but, in keeping with the regional pattern of low fault displacements, the central valley is more likely a low spot between two rising volcanic features. 
Joints

While structural data from faults are limited, the orientation of joints provides more detailed information. Over two hundred joint atti.tudes were collected from densely jointed outcrops. To analyze this data, four geographic domains were distinguished on the basis of prominent topographic features. For each domain, the poles to the joints were plotted in the upper hemisphere of an equal area net, and the data were contoured. This was accomplished by use of a joint analysis computer program developed by Fred Gullixson, Portland State University •

The contour diagrams are presented on Figures 15 and 16. Antelope and Cascade Ridges (Fig. 15) show a high concentration of flat-lying joints. Much of the Antelope Ridge data represents platy-type jointing, low dipping to horizontal, corresponding to primary flow layers. in the Antelope rhyolite. Joints formed normal to the direction of contraction in the cooling lava, in many cases coinciding with flow planes. The slight development of northwest dips may reflect the northwest-dipping Antelope rhyolite flows. Data from Cascade Ridge also show shallow west and southwest-dipping platy jointing also related to local primary flow directions. North-south joints and trends of $N 45^{\circ}-90^{\circ} \mathrm{W}$ may be related to regional stresses described earlier including the northdipping Cascade Ridge fault.

The Little Glass Butte joint data (Fig. 16) show a weak ring of fracture orientations having moderate to high 

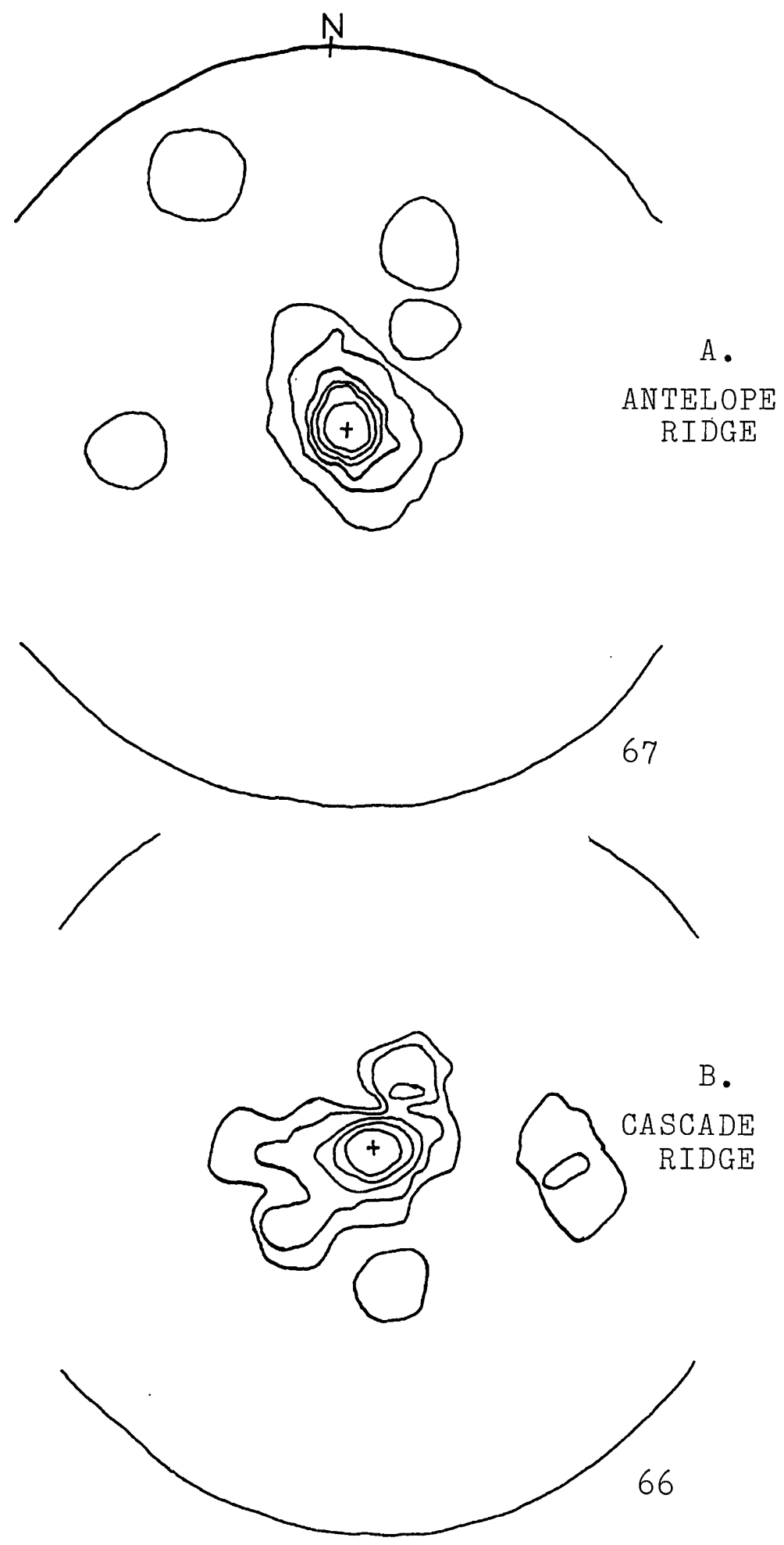

Figure 15. Stereograms of poles to joints, eastern study area. Contours are in the sequence $2 \%, 5 \%, 10 \%$, $15 \%, 20 \%, 25 \%, 30 \%$ per $1 \%$ area; number of data points at lower right. 

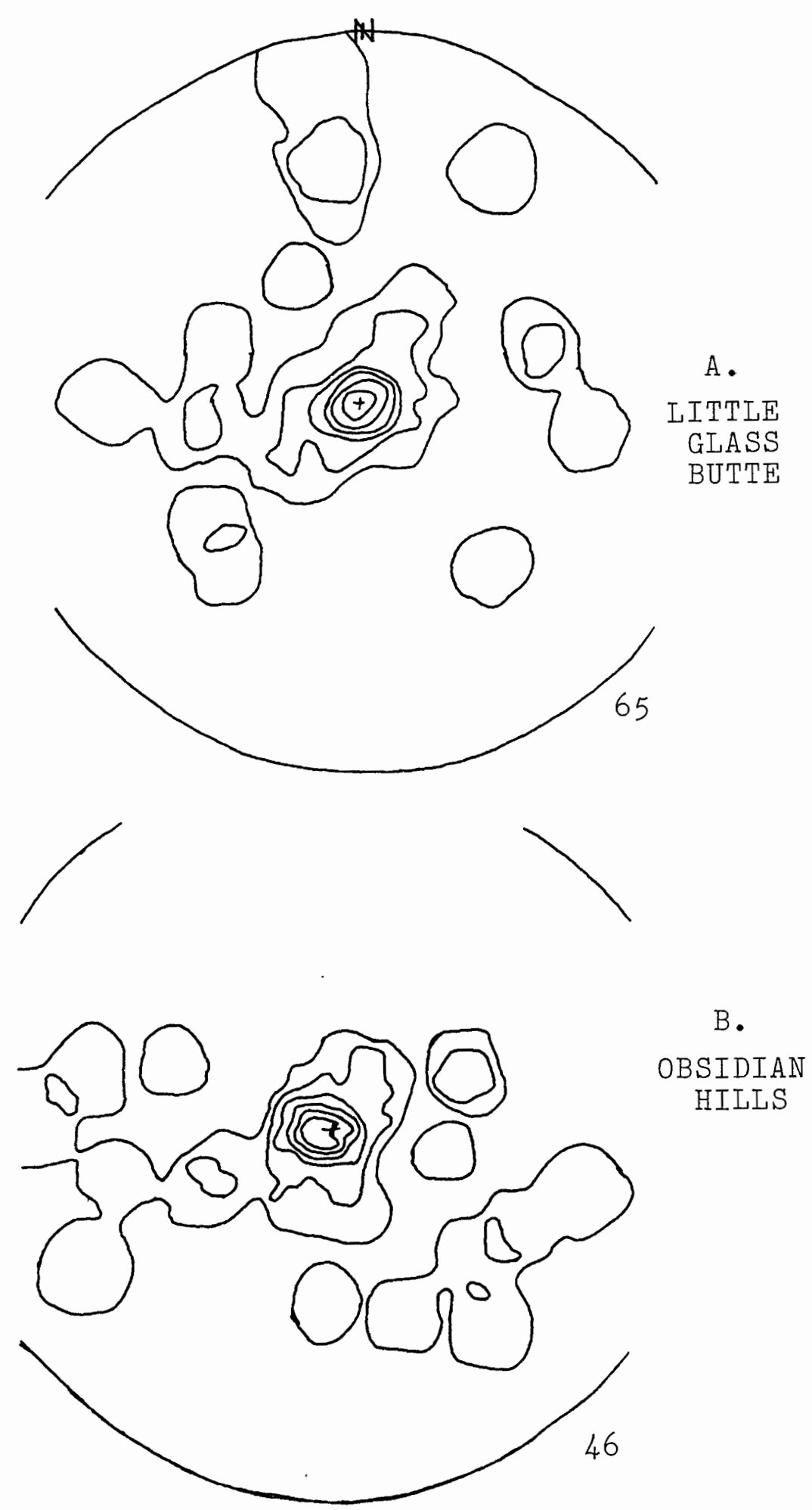

Figure 16. Stereograms of poles to joints, western study area. Contours are in the sequence $2 \%, 5 \%, 10 \%$, $15 \%, 20 \%, 25 \%, 30 \%$ per $1 \%$ area; number of data points at lower right. 
dips, in addition to a concentration of shallow-dipping to horizontal platy joints. This group of diversely oriented joints could have formed by doming of the butte after eruption of the rhyolite and obsidian flows (Wells, 1979; Steven and Lipman, 1976). Outcrops are not, however, continuous around the butte, and so doming is not supported by field evidence. The variety of joint attitudes may represent cooling fractures that formed along irregular flow bands. In the Obsidian Hills area (Fig. 16), a wide range of joint orientations dip to the south, that is, toward Iittle Glass Butte. Fractures ringing a dome were found by Steven and Lipman (1976) and Wells (1979) to dip toward the dome. This might partially support doming of Little Glass Butte, though data west and south of. the butte are lacking. These joints could also reflect gravity sliding ta. the south into the fault valley running between the Obsidian Hills and Little Glass Buttes domains.

Joint analysis only weakly supports the existence of the Cascade Ridge fault but illustrates some local influences (e.g. north-south structures) on the overall trend of the curving fault line. These local influences are a result of rock inhomogeneity, more than one period of fracturing, or nonuniformity of stress orientation or intensity (McKinstry, 1955). An example of nonuniform:stresses is the intersection of dominant structures (northwest-trending) with subordinate structures (north-south or northeast-trending). 
Joint intensity contour mapping could be applied in the Glass Buttes area. Pohn (1981) used joint intensity to locate the surface traces of faults, suggesting the observed decrease in intensity toward known faults resulted from release by faulting of stresses in adjacent rocks, thus inhibiting jointing. A study by Guth and others (1981) supported this conclusion, but joint intensity has elsewhere been found to increase in. the vicinity of faults (Wheeler and Dixon, 1980). The technique might be tested in areas of known faults, but otherwise appears unreliable.

RELATION OF LOCAL TO REGIONAL STRUCTURES

The Brothers fault zone contains discontinuous high angle en echelon normal faults. trending $N 25^{\circ}-50^{\circ} \mathrm{W}$ and shorter conjugate faults trending $N 40^{\circ}-60^{\circ} \mathrm{E}$, while the fracture zone has an overall trend of about. $N 60^{\circ} \mathrm{W}$. Experimentally produced shear zones contain similar configurations of fractures (Tchalenko, 1970), that is, have a dominant shear direction (for example, northwesterly) and a conjugate shear set that trends normal to the dominant. set (or northeasterly).

The Brothers fault zone may be only the northeast side of a northwest-trending right-lateral strike-slip system that is bounded to the southwest by the Eugene-Denio fault zone (see Fig. 4), and that encloses an area of northnortheast-trending Basin and Range faults (Lawrence, 1976).

The Cascade Ridge fault has features.suggesting strike-slip motion, but younger plateau basalt shows only 
normal faults. The lack of developed strike-slip faults at the surface may be due to concealment of the right-lateral structure by young volcanic and sedimentary rocks. Surface structures are known to develop in successive stages as a fault zone matures, or in the case of the Brothers fault zone, as the fault zone reappears through overlying strata. Initial structures are normal to the underlying fault, but with time the fractures become parallel (Fig. 17). The Brothers fault zone, according to this model, is in an early stage of development with respect to Cenozoic volcanic rock cover, with normal faults trending at a high angle to the underlying strike-slip fault and no through-going northwesterly faults.

Large dome, vent or caldera complexes are not located directly on the Brothers fault zone. The belt of silicic centers defined by MacLeod and others (19.76) trends more westerly. The exact relationship of these intersecting zones is an interesting tectonics problem, as described earlier, but beyond the scope of this study. It is not clear if the Brothers fault zone played any role in localizing eruptive centers, therefore dating fault zone activity by ages of nearby silicic rocks may not be valid.

Glass Buttes is at the intersection of the Brothers fault zone and the silicic volcanic zone. Its occurrence is related to the silicic volcanic zone, as well as to the dilational effect of the two intersecting systems. The influence of the regional structures can not be separated at 

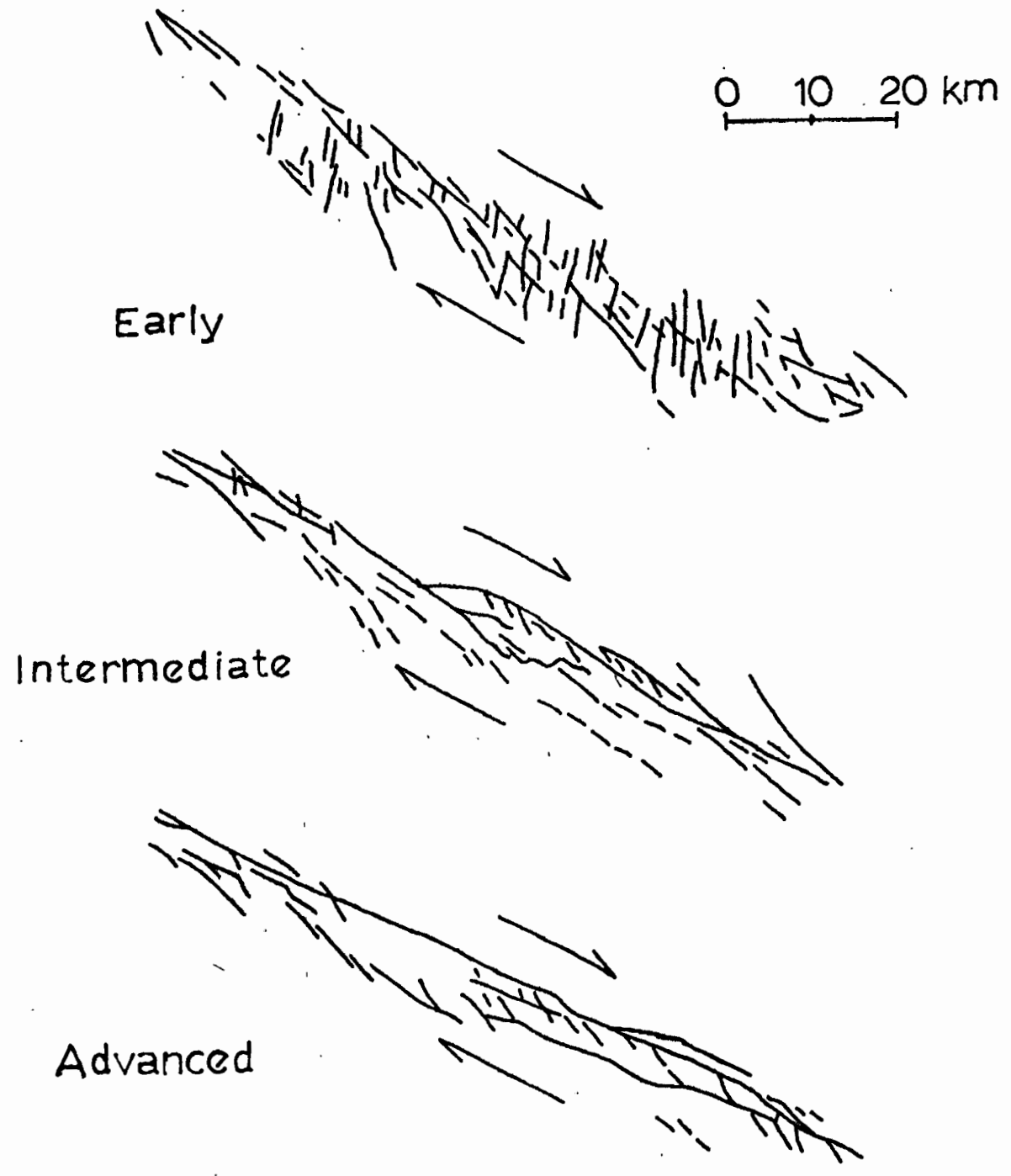

Figure 17. Successive development of surface structures overlying a right-lateral strike-slip fault. (Modified from Fig. 9.6, Hobbs and others, 1976.) 
Glass Buttes; as indicated earlier, there is only about a $20^{\circ}$ difference in the northwesterly trends of the two systems. Hydrothermal alteration and extremely glassy lavas, however, set Glass Buttes apart from most other complexes of the silicic zone, thus the structural intersection played a role in the rapid eruption of rhyolite as well as concentration of geothermal fluids.

Structures within and surrounding the eastern Glass Buttes are summarized in Table II. Joint and fault trends of $\mathrm{N} 40^{\circ}-60^{\circ} \mathrm{W}$ are common throughout the region and are related to the Brothers fault zone. The northeast-trending shears on the Brothers fault zone are expressed in the east Glass Buttes as abundant northeast-trending joints rather than fault scarps, and common trends are $N 40^{\circ}-60^{\circ} \mathrm{E}$.

\section{TABLE II}

SUMMARY OF STRUCTURES IN THE EASTERN GLASS BUTTES

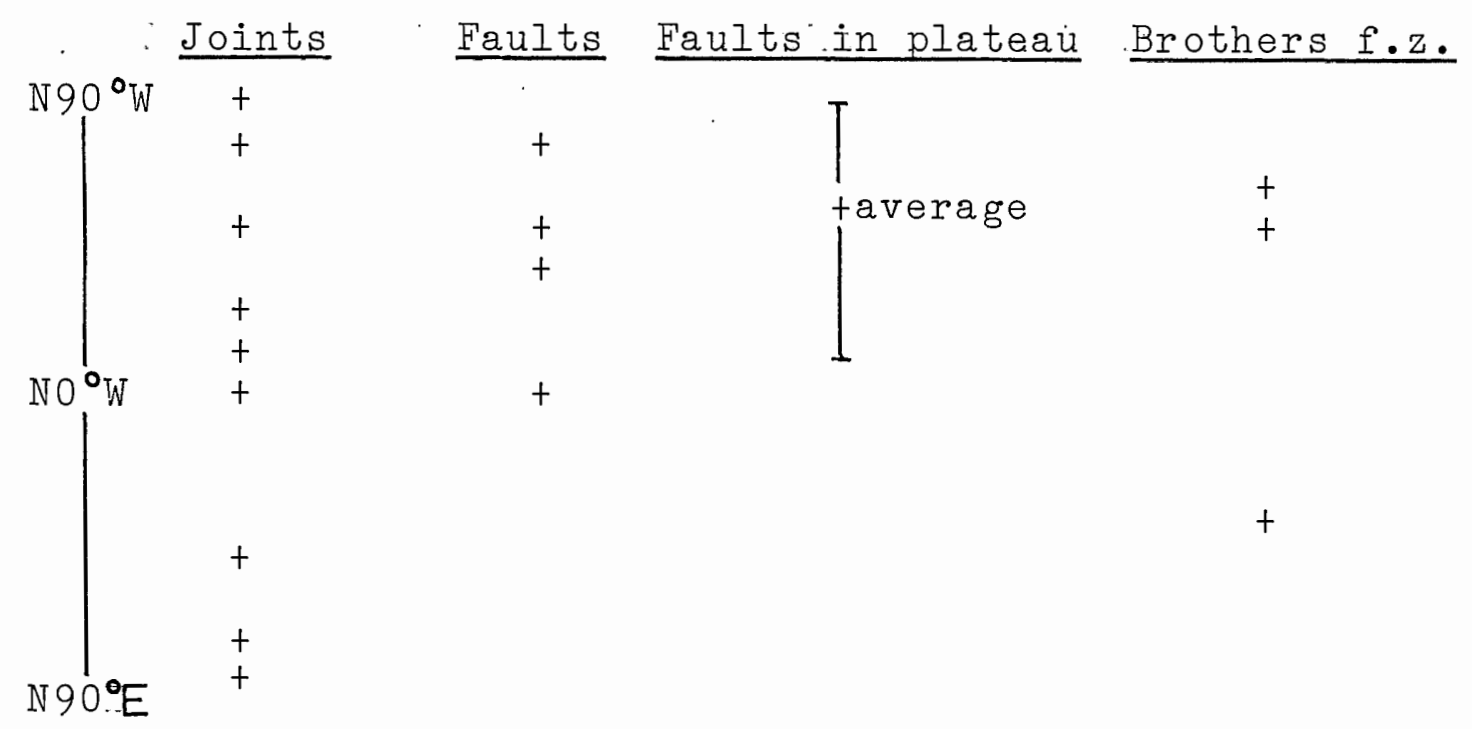


More westerly joint and fault trends may represent the influence of the silicic volcanic zone. As can be seen in the joint trends, the result of this intersection is a variety of fracture orientations. It is unclear if the two mineralized faults in the area, Cascade Ridge and Glass Butte mine faults, each trending $N 60^{\circ}-70^{\circ} \mathrm{W}$, are related solely to the Brothers fault zone or to the silicic zone. They may in fact be the product of both systems.

The possibility of strike-slip motion on faults at Glass Buttes deserves further study. Are curving fault planes with variable dips known to have greater horizontal than vertical displacements? Is strike-slip movement observed in other buttes of the silicic zone, away from the Brothers fault zone? Further structural analysis and definition of these two zones might help distinguish their effects upon Glass Buttes, at their point of intersection. 


\section{GEOCHEMISTRY}

Analyses were performed in order to chemically characterize the volcanic units at Glass Buttes. Major element chemistry of unaltered rocks was then compared with that of highly altered rocks to determine the effects of hydrothermal alteration on major element abundances. Chemistry of alteration is discussed in a later section.

Eighteen unaltered rocks were analysed, including rhyolite and obsidian flows, dome-related glass flows and flow breccias, and plateau basalt. Raw data are presented in Table III and were used in all graphic figures. Analyses normalized to 100 percent volatile-free with total iron as Feo may be found in the Appendix. These recalculations remove most effects of surface hydration and oxidation upon major element abundances. As indicated in the Appendix, AAS analyses are considered most reliable for $\mathrm{K}_{2} \mathrm{O}$, while varying up to 20 percent from XRF values for other major oxides. In the following discussion, XRF data (pre-normalized) are used and appear the more reliable.

Included in the Appendix with new analyses from Glass Buttes are previously published chemical compositions of Glass Buttes rhyolite and obsidian and trace and rare earth element data for Glass Buttes rhyolitic lava and obsidian. 


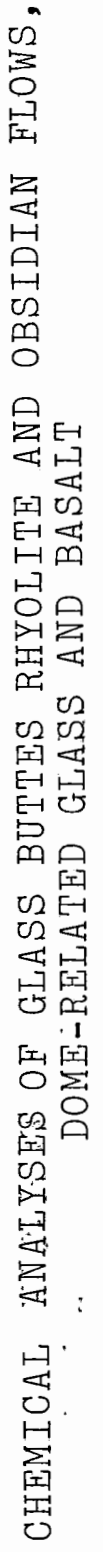

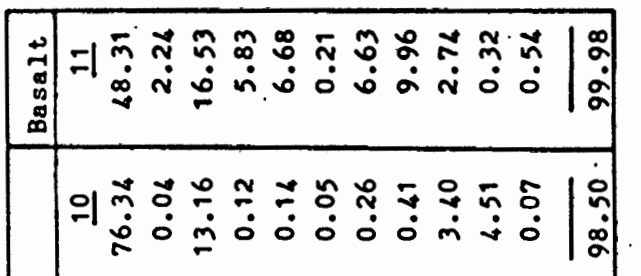

لِ

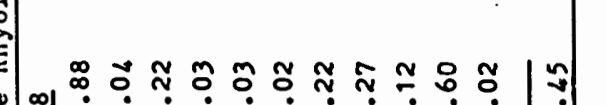

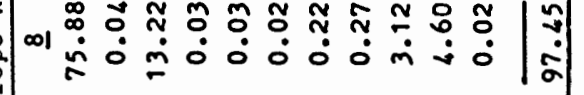

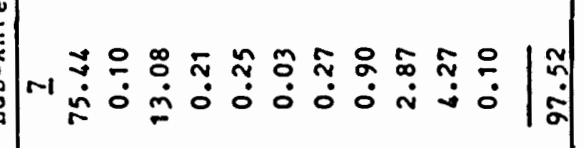

वे.

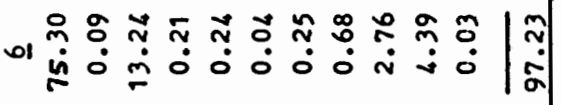

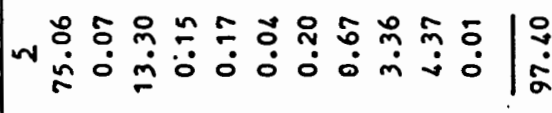

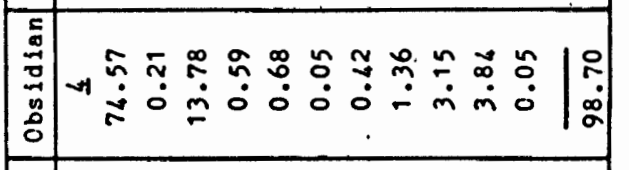

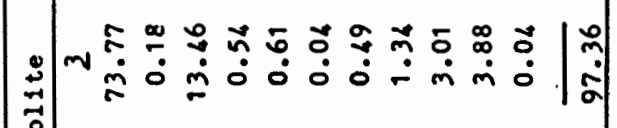

$\stackrel{\dot{ \pm}}{\mathrm{s}}$

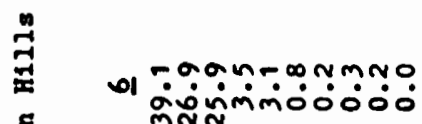

总

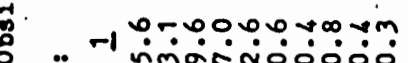

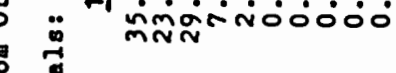

$\stackrel{4}{4}$

:

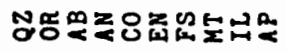

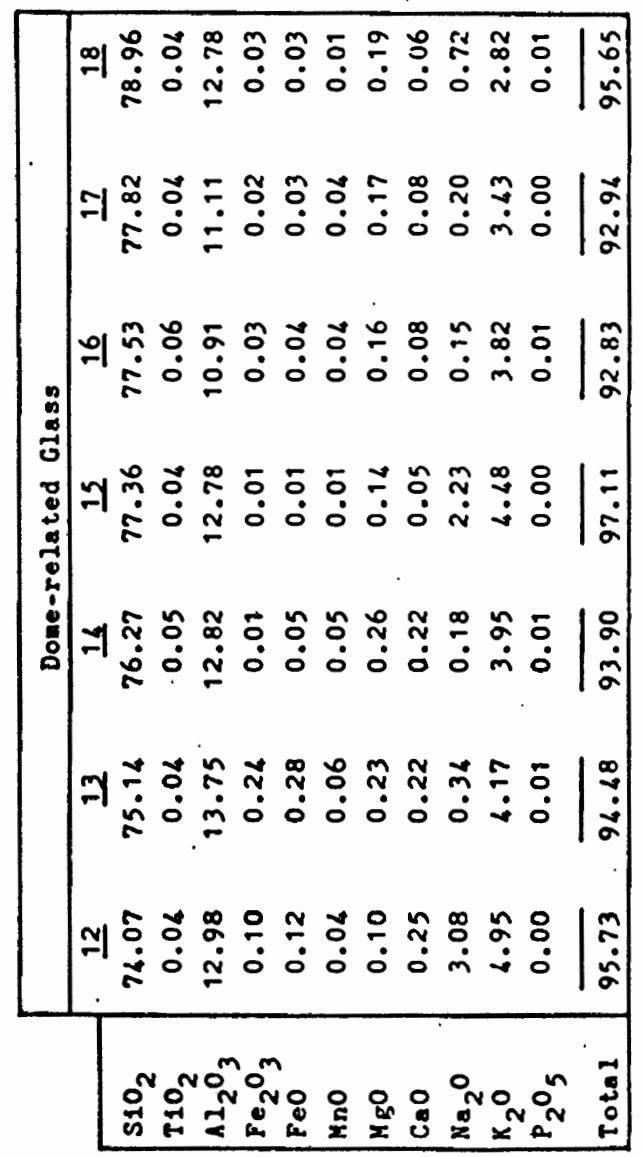


CHEMICAL CHARACTERISTICS

On the basis of silica content, all rocks are of rhyolitic composition ( 74 to 84 percent $\mathrm{SiO}_{2}$ ), except the basalt ( 48 percent $\mathrm{SiO}_{2}$ ), and are peraluminous. Harker variation diagrams of six major elements versus silica are presented in Fig. 18 for rhyolitic rocks.

Distinct chemical differences can be seen between the younger Little Glass Butte (LGB) rhyolite flow and the older LGB-Antelope rhyolite flows. The younger LGB rhyolite is lower in $\mathrm{SiO}_{2}$ and $\mathrm{K}_{2} \mathrm{O}$ and higher in $\mathrm{TiO}_{2}$, total iron, CaO and $\mathrm{MgO}$. Obsidian Hills obsidian overlying younger LGB rhyolite north of Little Glass Butte compares closely to the composition of the younger LGB rhyolite (Fig. 18) and.. suggests a genetic relationship; the obsidian may be the chilled selvage of the younger LGB rhyolite flow.

Dome rocks include masive glass flows, blocky pumice breccias, and finer flow breccias occurring on Antelope and Cascade Ridges. These rhyolitic rocks range from 80 to 84 percent $\mathrm{SiO}_{2}$. The dome rocks are very low in $\mathrm{Na}_{2} \mathrm{O}$, with the exception of a glass occurring at the southwest end of Cascade Ridge (sample number 12); that appears more closely related chemically to the older LGB-Antelope rhyolites group. An AF'M diagram for rhyolite and plateau basalt analyses (Fig. 19) shows a bimodal pattern of volcanic composition that is typical of the nearby Basin-Range province. The absence of intermediate-composition rocks is probably real, 

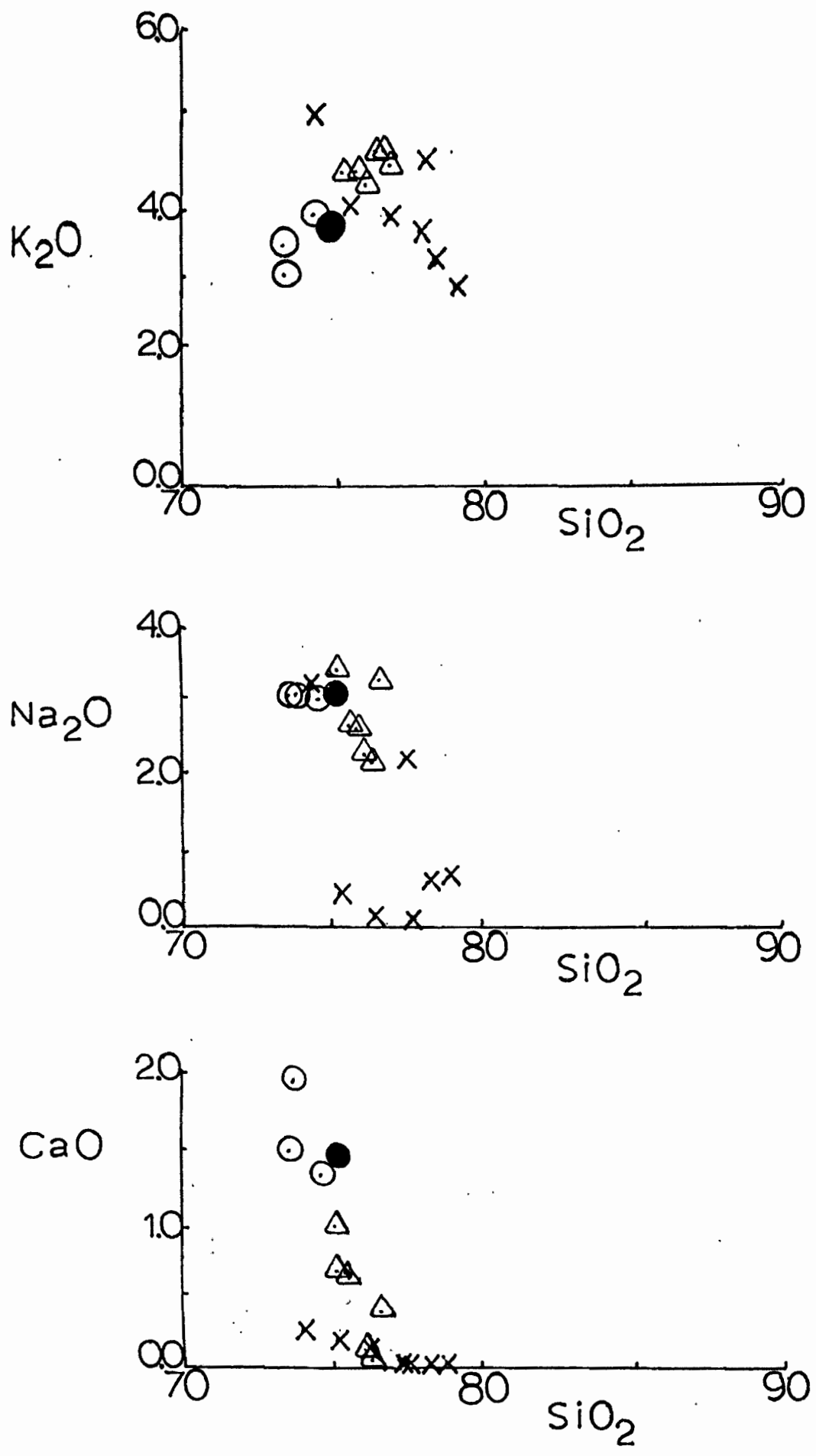

Figure 18. Major oxide variations versus silica. Key to symbols: open circles-younger LGB rhyolite flow; closed circle-Obsidian Hills obsidian flow; triangles-Antelope and older LGB rhyolite flows; $X^{\prime} s$ - Cascade and Antelope Ridges (dome-related rocks). 

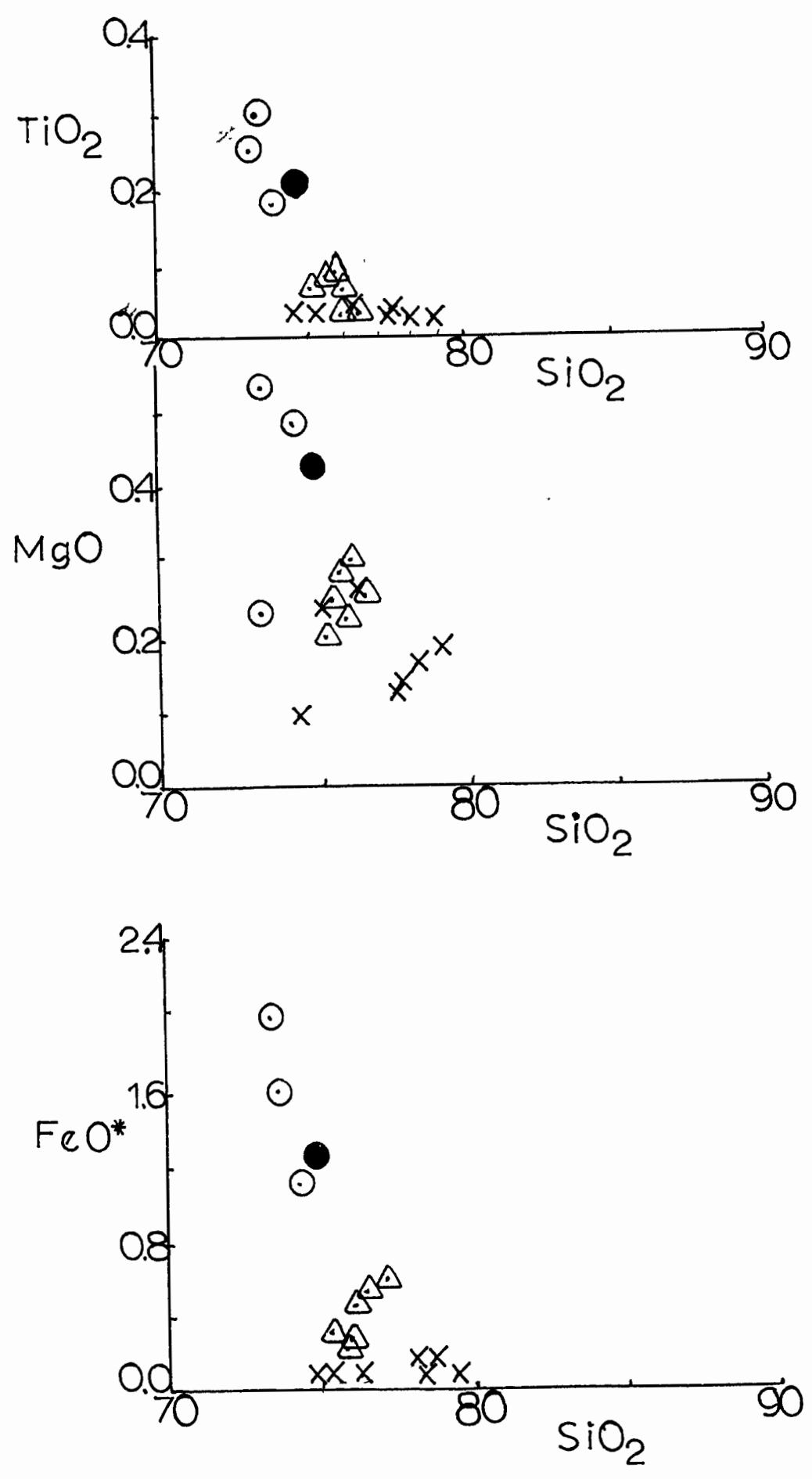

Figure 18. Continued. 


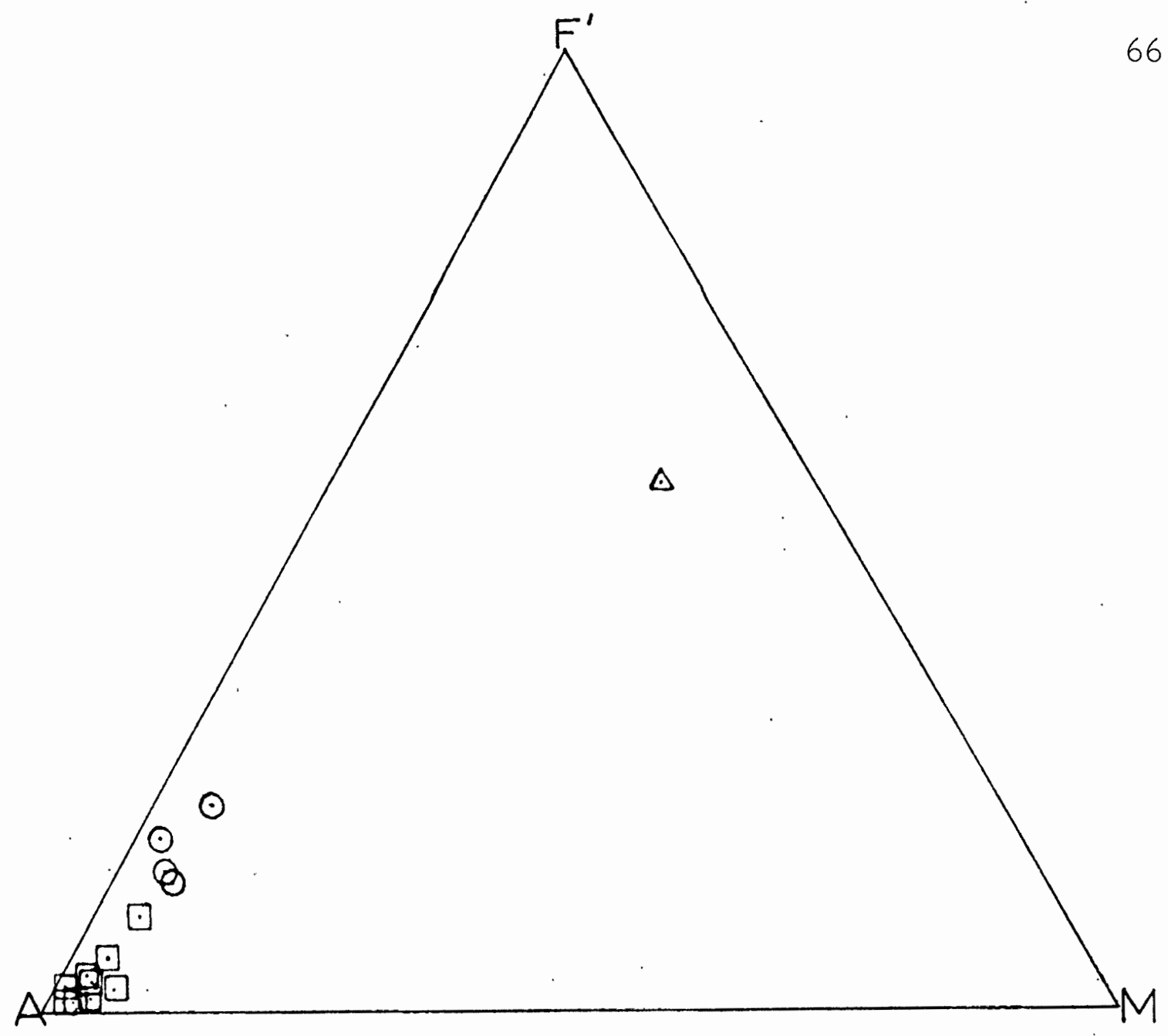

Figure 19. AF'M plot $\left(\mathrm{F}^{\prime}=\mathrm{FeO}^{\prime}+0.9 \mathrm{Fe}_{2} \mathrm{O}_{3}+\mathrm{MnO}\right)$. Symbols: triangle- plateau basalt; circles-younger Iittle Glass Butte rhyolite; squares- older LGB-Antelope rhyolites. 
although a detailed sampling and analysis program could reveal rocks formed from very low-volume eruptions that are andesitic in composition.

\section{DEVITRIFICATION AND HYDRATION}

Following eruption and emplacement, rhyolitic lavas undergo physical and chemical changes. The glassy envelope eventually devitrifies, or crystallizes, to cristobalite that may eventually hydrate to perlitic glass (Zielinski and others, 1977). The flow interior will have undergone vapor-phase crystallization that formed alkali feldspar and cristobalite.

Segregation of elements by devitrification has been observed in spherulites. Ewart (1971) showed spherulites are enriched in $\mathrm{Na}_{2} \mathrm{O}, \mathrm{SiO}_{2}$ and $\mathrm{CaO}$ compared to the glassy groundmass.

Hydration may occur after the flow has cooled, at which time the unstable natural glass, initially containing only 0.1 or 0.2 percent $\mathrm{H}_{2} \mathrm{O}$, may absorb substantial water (Lipman, 1965). Lipman (1965) and Noble (1967) found hydrated glass contained less $\mathrm{Na}_{2} \mathrm{O}$ and $\mathrm{SiO}_{2}$ compared to unhydrated obsidian nodules within the glass, while behavior of $\mathrm{K}_{2} \mathrm{O}$ was variable. Groundwater leaching further removes $\mathrm{Na}_{2} \mathrm{O}$ from glassy rocks (Noble, 1965). 


\section{DISCUSSION}

If the deviation of pre-normalized totals from 100 percent is largely volatile constituents, the following comparisons may be drawn. Volatile contents are up to 7 percent in the rhyolitic rocks and indicates alteration has occurred in varying amounts by hydration and vapor phase crystallization. Dome rocks (samples 12-through 18) contain the highest amount of volatiles, suggesting extensive hydration or absorption of $\mathrm{H}_{2} \mathrm{O}$ by the glass. Sodium depletion in most of these glasses also indicates hydration has occurred, as well as groundwater leaching of the inflated and frothy rocks. Hydration may decrease silica contents, but $\mathrm{SiO}_{2}$ is unusually high in the glasses. Volcanic gases, or vapor phase crystallization, may have silicified these rocks to some extent. Leaching of many other chemical components could also concentrate silica relative to other constituents.

The rhyolite and obsidian flows (samples 1 through 10) in contrast, show only slightly depleted $\mathrm{Na}_{2} \mathrm{O}$ (Brownlow, 1979). Samples 5 through 10 contain 1 to 2 percent more $\mathrm{SiO}_{2}$ than the average for rhyolites reported by Brownlow (1979). Volatile contents are also low, especially for obsidian (sample 4). Less hydration and leaching has occurred, therefore, than in the dome rocks, due to the higher density of 
the flow rocks. The slightly elevated silica contents could result from crystallization and/or silicification by a vapor phase much less voluminous than existed in the dome rocks.

Major element chemistry shows Glass Buttes compares closely with rhyolite and obsidian dome complexes in the western U. S. and within eastern Oregon (Boyd, 1961; Higgins 1973; Parker, 1974; Lipman, 1975; Walker, 1979; Wells, 1979). Its compositions show no deviation from that of other domes in the silicic volcanic zone of MacLeod and others (1976).

Until intermediate rock types are found at Glass Buttes, a bimodal style of volcanism is presumed. Waters (1927a) describes an older basalt unit found in the west buttes that he believed was correlative with the late Miocene Steens Basalt. This older basalt may represent the lowsilica end of a genetic suite of rocks that has culminated in the rhyolite observed in the east buttes, but it is more likely that Waters' older basalt is actually an interfingering internal basalt as found in the eastern buttes and part of a bimodal eruption suite.

Strong europium depletions found here and elsewhere in eastern Oregon (Beeson, 1969) indicate the rhyolitic rocks formed from a relatively low-temperature partial melt of the crust that was removed from parent material. The siliceous magma was then routed to the surface along fault channels. 
Temperature and depth of melting were such that europiumbearing feldspar minerals remained stable. If no hydrous minerals remained in the parent rock, the next stage of melting would occur at an elevated temperature and be of basaltic composition (Yoder, 1973). Hence, no lavas of intermediate composition would have formed.

Isotopic and trace element data for the feldsparrich internal basalt of the eastern Glass Buttes may in the future reveal its mode of origin, contamination by silicic crustal rocks, and any relationship to the plateau basalt. 


\section{HYDROTHERMAL ALTERATION}

\section{ALTERED SURFACE ROCKS}

Alteration of rhyolitic rocks by thermal fluids has occurred in the eastern Glass Buttes, and is confined to the northeast flanks of Cascade Ridge and the west half of Antelope Ridge. Silicification is the dominant type of hydrothermal alteration, in which silica-saturated fluids replaced wall rock and formed opalite. Advanced argillic alteration zones occur irregularly with opalite. Isolated fossil fumaroles show leached and oxidized surroundings. Following the discovery of cinnabar deposits, numerous trenches and pits were excavated across the east part of the field area. Natural outcrop of silicified rocks was not found, so the following described rocks are loosely termed "surface rocks".

\section{Opalized Rhyolite}

Most commonly found at the west end of Antelope Ridge, thoroughly silicified, flow-banded rhyolite varies in color from brilliant white to pink, beige, or brown. The luster of the rock varies from dull and chalky to translucent and glassy. Bright red granular cinnabar coats fracture surfaces and is often finely disseminated within the opalite. Disseminated hematite may impart an orangish-brown color to opalite. 
Often a remnant layered structure can be seen in these rocks that is similar to nearby outcrops of unaltered Antelope rhyolite. Silicification is incomplete in places, leaving irregular lenses of fresh-looking banded rhyolite (Fig. 20) within the opalite.

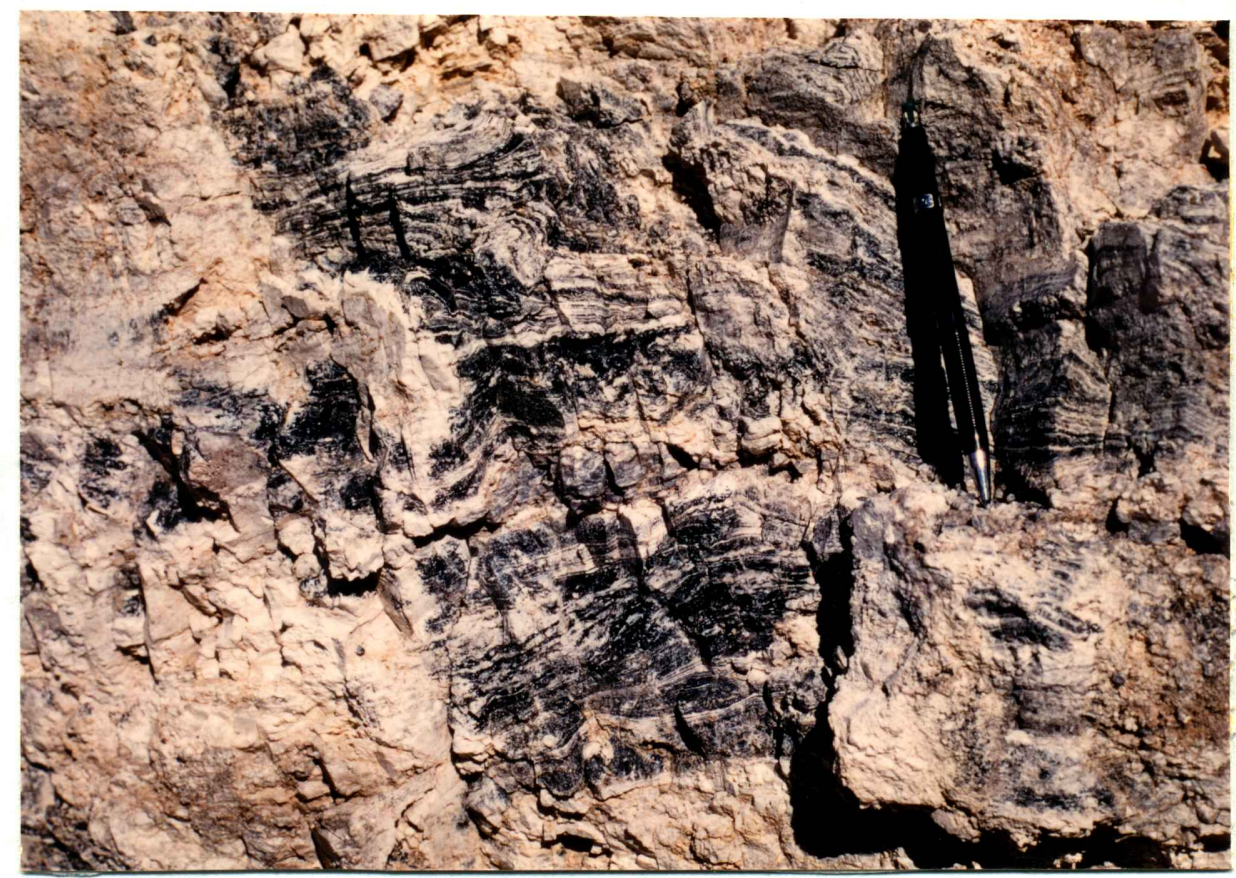

Figure 20. Incomplete opalization of rhyolitic glass; pit 1, west flank Antelope Ridge.

The brittle, opalized rocks are often broken by fractures that may or may not be resealed with opalite. Cementing opalite locally may contain disseminated cinnabar. These breccia zones commonly trend $\mathrm{N} 50^{\circ}-85^{\circ} \mathrm{E}$.

Opalized Tuff

A single sample of opalized tuff was found in pits on the west flank of Antelope Ridge. Colored a striking 
pinkish-brown, the rock is fine-grained, containing rare orangish-brown fragments up to $2 \mathrm{~cm}$ across that show basalt textures of iron oxide surrounding skeletal lathshaped grains. Smaller fragments are rounded pumiceous glass, white to yellow in color.

No other explosive volcanic rocks were found on Antelope Ridge. This opalized tuff underlies unaltered Antelope rhyolite flows, but its relationship to dome glass flows is uncertain.

\section{Argilic Alteration}

Scattered occurrences of argillized rocks can be found, the largest mass being adjacent to the fault scarp exposed in the Cascade mine pit at the east end of Cascade Ridge (see Fig. 2). Incoherent masses of yellowish-brown clay extend into the hanging wall of the Cascade Ridge fault for at least $4 \mathrm{~m}$. Much opalite on Antelope Ridge shows similar argillaceous material forming irregular pockets or lenses within the opalite (Fig. 21).

X-ray diffraction analyses of these clays produced a broad, diffuse peak centered about cristobalite, indicating amorphous, noncrystalline material, as obtained from the glassy rhyolite in Fig. 7d. Amorphous clays are often associated with advanced argillic alteration common in supergene environments, where clays grade into opaline silica (Meyer and Hemley, 1967). Dickite, kaolinite, sericite, quartz, pyrite and alunite may accompany amorphous 


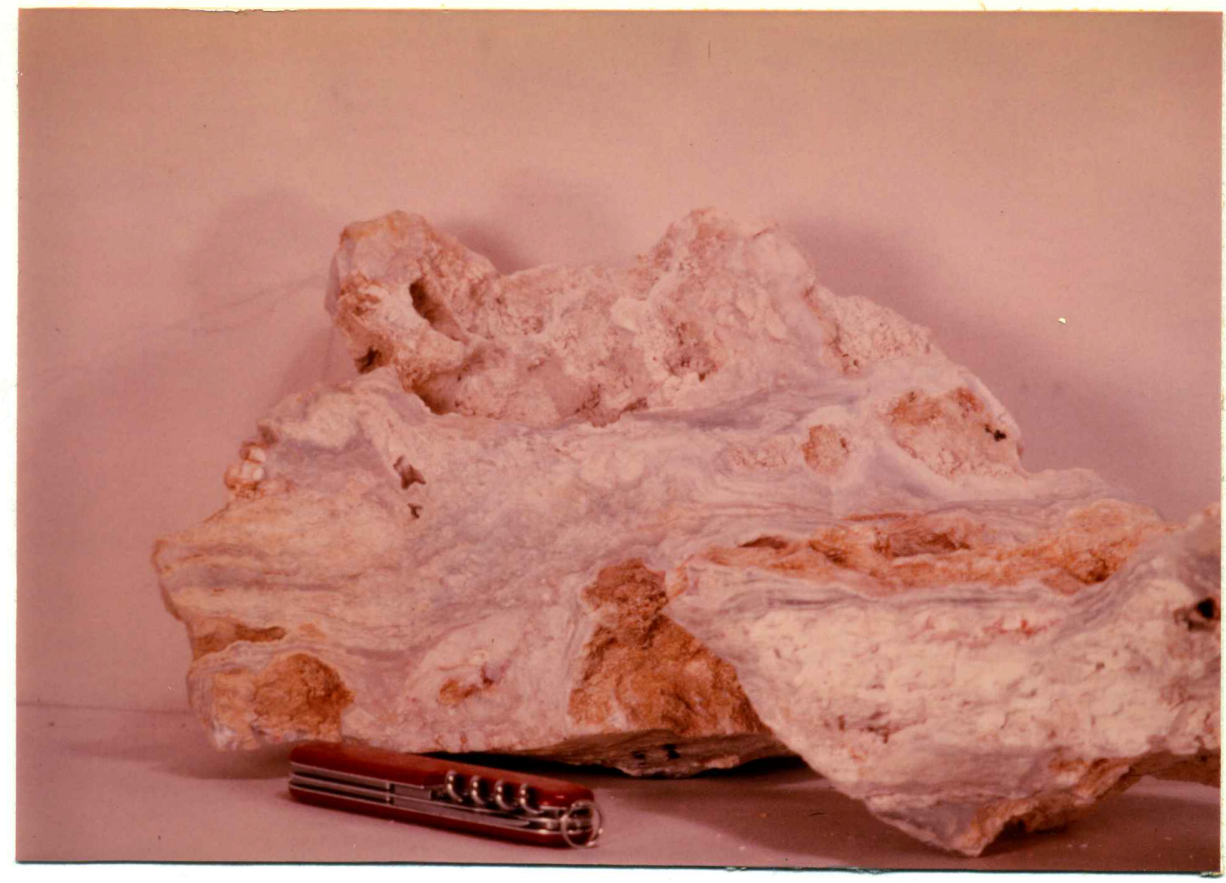

Figure 21. Leached opalite with clay lenses. From mining pits, west flank Antelope Ridge.

clays. Figure 22 is an X-ray diffraction pattern of amorphous clay from the Cascade mine area, showing two alunite peaks, first order at $2.99 \AA\left(29.9^{\circ} 2 \theta\right)$, second order peak at $2.89 \AA\left(30.9^{\circ} 2 \theta\right)$. A broad and diffuse cristobalite rise was also obtained, but no other crystalline material was detected with the amorphous clays.

\section{Fumarolic Alteration}

Several small, isolated areas are located on both Cascade Ridge and Antelope Ridge in which a 4 to $6 \mathrm{~m}^{2}$ section of rhyolitic bedrock is altered to friable, rubbly exposures of dark red-brown rock. Bits of unaltered rock can be found within the piles. Fumarolic alteration of the pumice breccia of Cascade Ridge has thoroughly decomposed and permeated the rocks. The frothy pumice blocks in the 


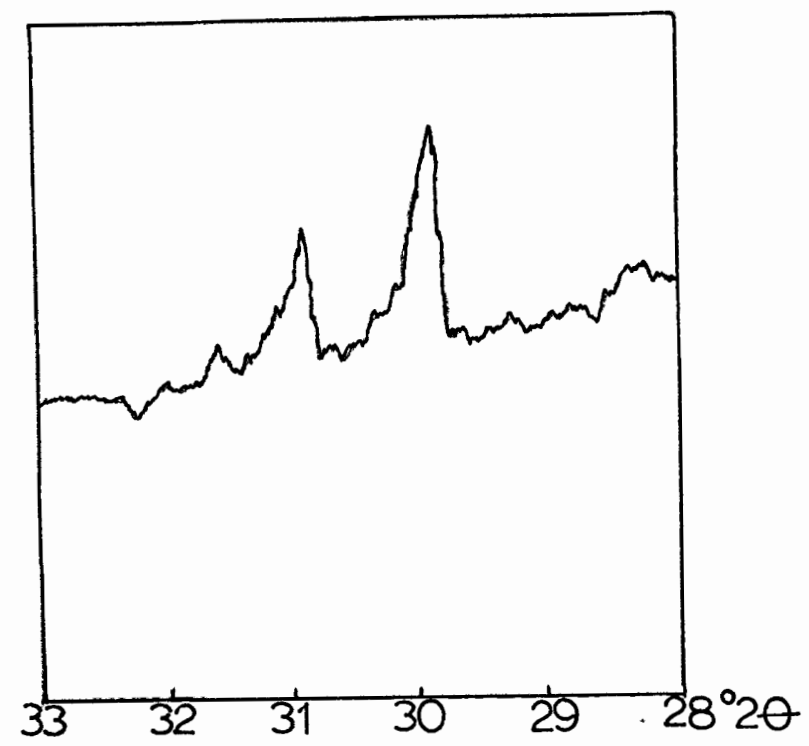

Figure 22. $\mathrm{X}$-ray diffraction pattern from $28^{\circ}$ to $33^{\circ} 20$ of amorphous clay from Cascade mine area. First and second order peaks of alunite are shown, at $29.9^{\circ}$ $2 \theta \cdot(2.99 \AA)$ and at $30.9^{\circ} 2 \theta(2.89 . \AA)$, respectively.

pumice breccia are reddish-orange and color intensifies toward the margins of the blocks (Fig. 23). The less permeable matrix material is chalky white.

Numerous exposures on Antelope Ridge show flow-banded rhyolite locally having dark reddish-brown fracture coating. Where concentrated, this iron oxide material is botryoidal and often coated with clear silica (hyalite).

These zones are believed to be the result of fumarolic activity (White, 1955) that leaked fluid from the larger hydrothermal system underlying Antelope and Cascade Ridges.

Bleached Rocks

Strongly bleached rocks are a guide to alteration (Schwartz, 1955) and were found along the entire length of . 


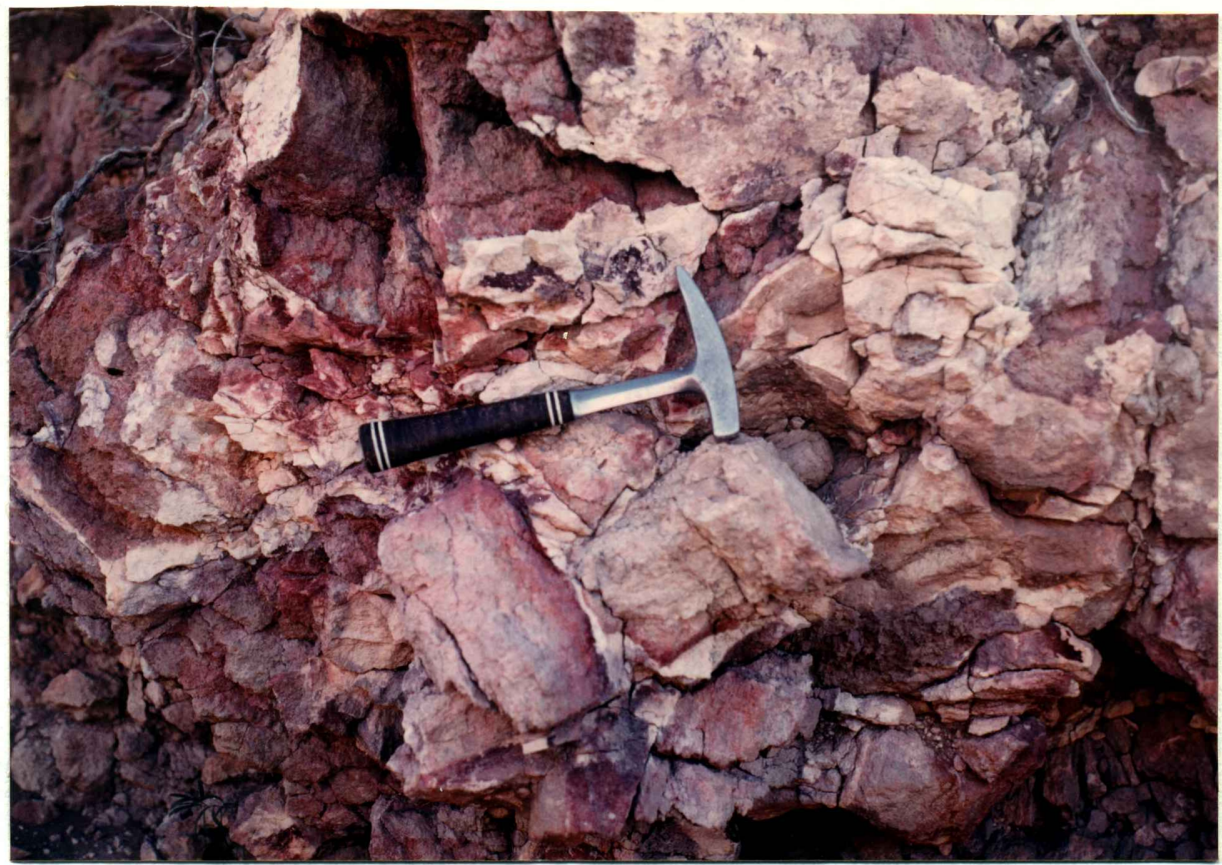

Figure 23. Stained pumice blocks in pumice breccia, fumarolically altered. West end, Cascade Ridge.

Antelope Ridge. Bleached Antelope rhyolite is variously discolored, from pink to red to purple, but with a dull, chalky luster. X-ray diffraction detected no clay minerals, and so bleaching may have resulted by leaching of iron from mafic minerals in the rhyolite, as suggested by Hulen (1978) in a study of the Coso Geothermal Area, California. Scatteréd reddish-brown fumarolic fracture coating also found in the rhyolite suggests leaching was accomplished by vapors escaping the underlying hydrothermal system on Antelope Ridge.

Sulfides

Cinnabar is abundant in the highly altered west Antelope Ridge opalite (vicinity of Glass Butte mine) and the east Cascade Ridge opalite (vicinity of Cascade mine). 
It occurs as a fine, granular coating or thin film on fractured surfaces and cavities, in very thin veins within opalite, or as finely disseminated grains in large opalite masses. The cinnabar may be confused with the reddishbrown granular hematite that often coats fractures in cinnabar-bearing opalite. The bright red to pink color of the cinnabar generally distinguished it from hematite.

Pyrite is not present in surface rocks, though it is common in drill cuttings, as described below. At higher levels in the hydrothermal system, iron was apparently oxidized to hematite.

\section{Hyalite}

Botryoidal or smooth fracture coatings of hyalite (clear amorphous silica) are found throughout the field area, but only in the eastern portion is it found coating hematite in fumarolically altered sites. Hyalite is rarely found in areas of extensive silicification. Since the hyalite is commonly associated with fumarolic alteration, it may have been a constituent of a vapor that transported iron in the eastern buttes. Elsewhere, the occurrence of hyalite alone may indicate a lower temperature hydrothermal vapor or liquid (e.g. volcanic gases) penetrated the surface, but was unable to thoroughly alter surrounding rocks as in the fumarole areas to the east.

The fumaroles at Glass Buttes are believed to postdate opalite formation, thus the hyalite in the eastern 
buttes also post-dates the opalite. Hyalite lines vugs in opal veinlets of the Coso Geothermal Area (Hulen, 1978), indicating it formed separately and after the opal.

The temperature relations of hyalite are unknown. Its existence in the western buttes with no other signs of thermal activity suggests, 1) it may be of relatively low temperature, 2) if it represents last gasps from the hydrothermal system, the system may be shifting westward at the same time as it is receding to depth, and 3) the hyalite may represent volcanic gases from sources separate from the eastern hydrothermal system, e.g. related to cooling lavas or gas-effusion along the axis of a dome. These possibilities deserve further study.

\section{STRUCTURES RELATED TO ALTERATION}

The northwest-trending Cascade Ridge and Glass Butte mine faults are the major loci of alteration at Glass Buttes. Sites of past fumarolic activity, intensive silicification and mercury mineralization are localized along the trend of these two faults.

\section{Cascade Ridge}

The Cascade mine, located at the east end of Cascade Ridge (Fig. 24), consists of a large open pit exposing a fault scarp about $16 \mathrm{~m}$ high. The scarp trends about $\mathrm{N} 45^{\circ} \mathrm{W}$ at the east edge and curves to about $N 65^{\circ} \mathrm{W}$ at the west edge of the exposure, dipping $60^{\circ} \mathrm{N}$ at the center to $70^{\circ} \mathrm{N}$ at 


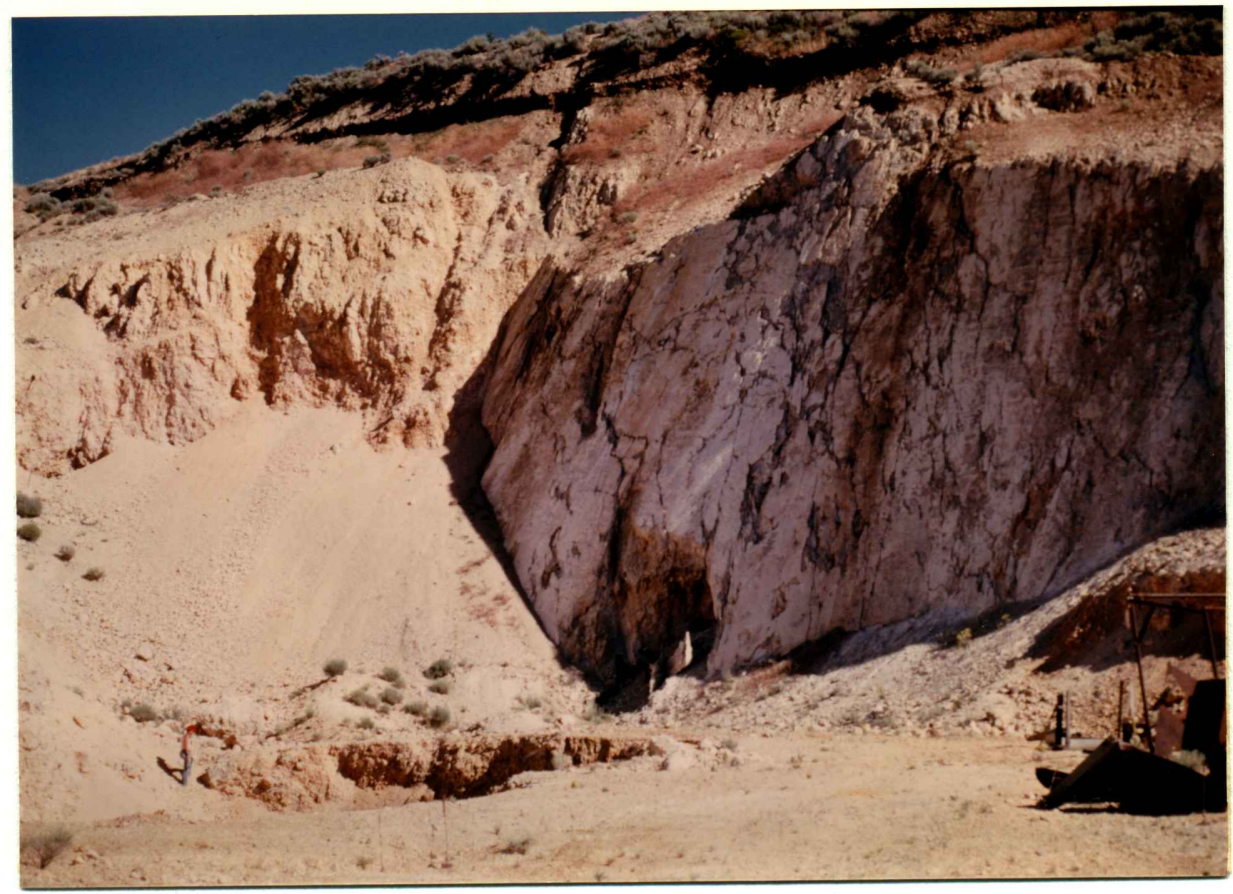

Figure 24. Cascade mine, northeast Cascade Ridge. View is to southeast, showing Cascade Ridge fault scarp. Note horizontal ridges in upper right half of scarp. Person at lower left for scale.

the edges of the scarp. Trenches throughout the north flank of Cascade Ridge expose masses of white opalite, but cinnabar is associated with the opalite only at the Cascade mine area. The previously suggested intersection of the Cascade Ridge and Glass Butte mine faults at the Cascade mine area provides a favorable site for ore concentration. Brooks (1963) found cinnabar concentrated in brecciated opalite along northwest-trending fractures in the tunnel pictured at the center in Figure 24.

The surface of the scarp is a cemented opalite breccia. Both cement and breccia fragments contain cinnabar. Silicification has occurred into the footwall, and the hanging wall material is argillized, grading outward into fresh, massive 
dome-type rhyolitic glass. Horizontal ridges across the scarp noted earlier are suggestive of strike-slip movement along the fault.

\section{Antelope Ridge}

Brooks' investigation of quicksilver deposits in Oregon also describes the Glass Butte mine, located on the north-central flank of Antelope Ridge (see Fig. 2; Brooks, 1963). Concentration of cinnabar occurs along a fault surface curving from $N 58^{\circ} \mathrm{W}$ at the east to $\mathrm{N} 80^{\circ} \mathrm{W}$ at the west end. The fault dips steeply to. the north at each end, and less steeply at its center. The dipping fault surface is a thick opaline breccia recemented with cinnabar-bearing silica, similar to the Cascade Ridge fault scarp. This type of structure formed a cap on rising ore fluids, which concentrated cinnabar in the footwall zone of both the Glass Butte mine fault and the Cascade Ridge fault.

The surface attitude of the Glass Butte mine fault was $\mathrm{N} 53^{\circ} \mathrm{W}, 53^{\circ} \mathrm{N}$; less than $2 \mathrm{~m}$ southwest of the fault scarp is a large smooth joint surface in the opalized footwall that trended $\mathrm{N} 87^{\circ} \mathrm{E}, 70^{\circ} \mathrm{N}$.

Pits on the northwest flank of Antelope Ridge have exposed a dark blue to grey rhyolitic glass. In the southern pit 1 (Fig. 25), the glass shows progressive replacement by opaline material from east to west; the replacing material is at first clay, then brittle opalite veins, and finally massive mineralized opalite, over a lateral distance of 


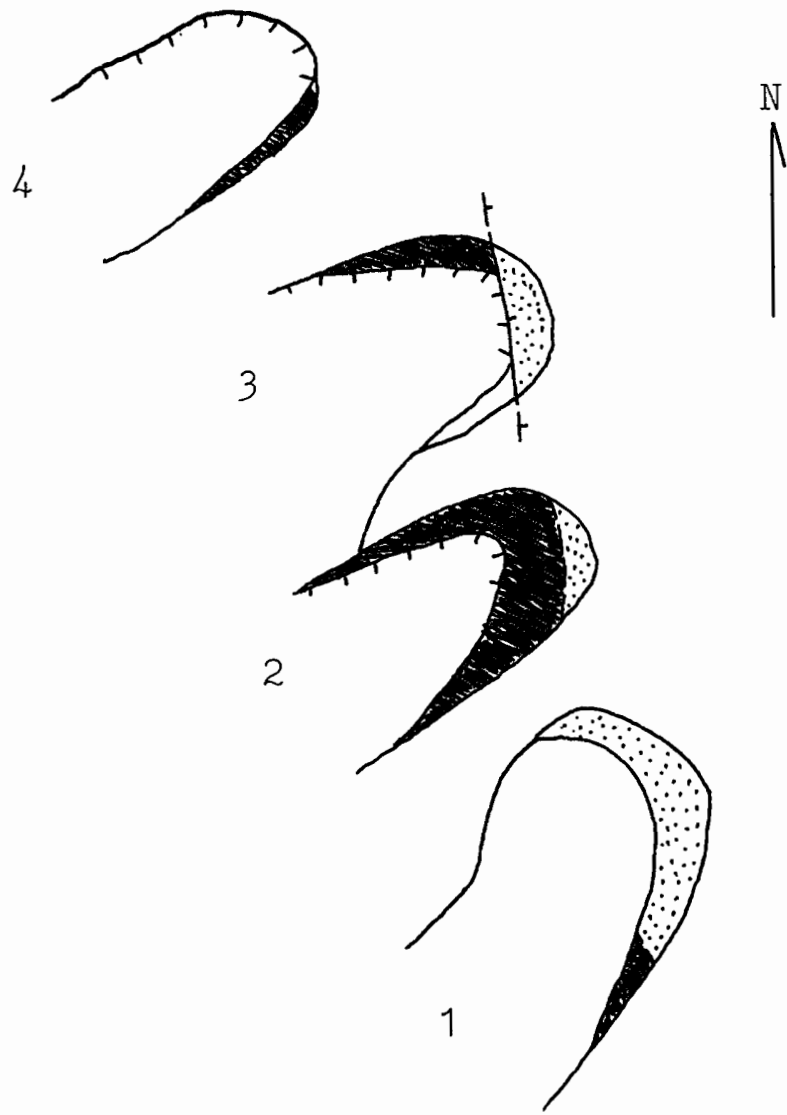

Figure 25. Mining pits, west flank Antelope Ridge. Showing relations of opalite (stippled) to blue glass ( shaded), and fault in pit 3 trending $N 0-10^{\circ} \mathrm{W}$. Pit numbers refer to text. (Scale $1 \mathrm{~cm}=0.3 \mathrm{~km}$ )

$15 \mathrm{~m}$. The next pit to the north, pit 2, also exposes this gradation. Further north in pit 3, the glass forms the north and south walls of the pit while the east wall is opalite. The borders of the opalite trend about $\mathrm{NO}-10^{\circ} \mathrm{W}$ across the pits. Unaltered glass is exposed in the northern pit 4. 
The sharp vertical contact of glass with opalite in pit 3 suggests this is a faulted surface trending NO-10 $\mathrm{W}$. Although banding in the glass is slightly contorted, there is no evidence of flow breccia, as expected if this were a depositional contact of glass against an up-faulted mass of opalite. A 6-cm thick, sharply defined zone of contact alteration is present, and the glass does not show obvious chemical alteration. Fragments of fresh, dark blue glass are found within the soft, clayey gouge zone. The clayey zone also contains coneentrations of pink to bright red cinnabar, and grades into leached opalite having pockets and Ienses of argillaceous material. About $26 \mathrm{~cm}$ away from the gouge zone, opalite becomes more dense and unaltered. The clay zone corresponds to a fault surface that fractured the opalite, displacing it next to dense rhyolitic glass, and allowed cinnabar-bearing fluids to leach opalite in a zone at least $25 \mathrm{~cm}$ wide, while the clayey fault gouge trapped cinnabar. Cinnabar may be related to a fluid either transporting mercury from depth, or leaching it from neighboring opalite. Curiously, the fault is not sealed with opalite, despite leaching by the hydrothermal fluid of opaline wall rock.

Another north-northeast-trending structure, intersecting Cascade and Antelope Ridges, could be proposed to tie together fumarolically altered areas on the ridges, but lack of further field evidence does not justify this. 
Discussion

The relation of certain fracture sets to different styles of silicification (including opalization with or without cinnabar, brecciation of opalite, or hyalite fracture coating) remains relatively unknown. Silicification and mineralization must have occurred in at least two episodes; brecciated opalite is itself cemented by opalite. It has not, however, been possible to describe fractures dominant during one specific hydrothermal surge. The major faults described above are northwest-trending, while conjugate fractures such as breccia zones and large joint sets in opalite trend $N 50^{\circ}-85^{\circ} \mathrm{E}$. Although many of these breccia zones are filled with silica and cinnabar, an equal number are barren and not recemented. Fracturing, then, continued after alteration had ceased.

Additional evidence exists for faulting and volcanism occurring after alteration. The fault cutting opalite in pit 3 on Antelope Ridge indicates faulting occurred after opalite development. Opalized pumice breccia common on the northeast flank of Cascade Ridge has an abrupt depositional contact with overlying unaltered flow breccia. A similar contact was observed in drill cuttings from north of Antelope Ridge, described later.

Continued eruptions during or after operation of the near-surface hydrothermal system may have capped or chokedoff fluid circulation that formed massive opalite bodies, 
although fumaroles continued to leak fluids from isolated points along Cascade Ridge and Antelope Ridge, altering younger rocks.

\section{CHEMISTRY OF ALTERATION}

The principal types of alteration at Glass Buttes are silicification and advanced argillic alteration. Silicification is accomplished by hydrothermal addition or selective leaching of cations leaving only residual silica. Removal of aluminum may be complete, and calcium and sodium are often strongly depleted; potassium may be depleted if alkali feldspars: are destroyed (Meyer and Hemley, 1967). The advanced argillic assemblage, associated with and grading into opaline silica, includes clays, alunite, pyrite and quartz. Amorphous clays of this assemblage are common in a supergene environment described in the next section, and represent a zone of lower aluminum mobility.

The predominant type of alteration is silicification by water-saturated fluids, supersaturated with amorphous silica. Thëse altered rocks contain 86 to 94 percent $\mathrm{SiO}_{2}$, and are strongly to totally depleted in alkalis, iron, and aluminum (Table IV). The extremely high volatile contents, inferred from pre-normalization totals of 88 to 95 percent, reflect the large amount of $\mathrm{H}_{2} \mathrm{O}$ in opaline silica.

Patterns in distribution of major element abundances for rhyolitic rocks show distinctly the areas of most intense 
TABLE IV

CHEMICAL ANALYSES OF SILICIFIED ROCKS

\begin{tabular}{|c|c|c|c|c|c|c|c|}
\hline & \multicolumn{5}{|c|}{ Antelope Ridge } & \multicolumn{2}{|c|}{ Cascade R1dge } \\
\hline & 12 & $\underline{20}$ & 21 & $\underline{22}$ & 23 & 24 & 25 \\
\hline $\mathrm{SiO}_{2}$ & 86.33 & 88.86 & 91.64 & 93.65 & 94.44 & 90.72 & 91.38 \\
\hline $\mathrm{T} \mathrm{O}_{2}$ & 0.04 & 0.08 & 0.08 & 0.06 & 0.04 & 0.06 & 0.04 \\
\hline $1_{2} \mathrm{O}_{3}$ & 1.03 & 0.23 & 0.26 & 0.03 & 0.11 & 0.11 & 0.24 \\
\hline $\mathrm{Fe}_{2} \mathrm{O}_{3}$ & 0.00 & 0.00 & 0.00 & 0.00 & 0.00 & 0.00 & 0.00 \\
\hline FeO & 0.00 & 0.00 & 0.00 & 0.00 & 0.00 & 0.00 & 0.00 \\
\hline Mno & 0.00 & 0.00 & 0.00 & 0.00 & 0.00 & 0.00 & 0.00 \\
\hline $\mathrm{MgO}$ & 0.15 & 0.15 & 0.12 & 0.06 & 0.11 & 0.14 & 0.16 \\
\hline $\mathrm{CaO}$ & 0.02 & 0.03 & 0.04 & 0.03 & 0.03 & 0.03 & 0.03 \\
\hline $\mathrm{Na}_{2} \mathrm{O}$ & 0.00 & 0.00 & 0.01 & 0.15 & 0.20 & 0.00 & 0.09 \\
\hline $\mathrm{K}_{2} \mathrm{O}$ & 0.05 & 0.06 & 0.05 & 0.05 & 0.05 & 0.05 & 0.07 \\
\hline $\mathrm{P}_{2} \mathrm{O}_{5}$ & 0.00 & 0.01 & 0.01 & 0.01 & 0.01 & 0.01 & 0.01 \\
\hline Total & 87.62 & 89.42 & 92.21 & 94.31 & 94.99 & 91.12 & 92.02 \\
\hline
\end{tabular}

hydrothermal alteration in the eastern Glass Buttes. Figure 26 illustrates the geographic distribution of nine major oxide abundances across the field area.

Titanium and magnesium are exceptions to the nearly total leaching of major elements in opalized rocks. With the exception of the younger Little Glass Butte rhyolite and obsidian (samples 1 through 4, Table IV), titanium contents are consistent over most of the study area, ranging from 0.04 to 0.10 percent, with no gain or Ioss of titanium over areas of alteration. Finlow-Bates and Stumpfl (1981) demonstrated this immobility of titanium during intense hydrothermal alteration.

The $\mathrm{TiO}_{2}$ versus $\mathrm{SiO}_{2}$ graph in Figure 27 indicates $\mathrm{TiO}_{2}$ values for opalite fall in a range similar to that of Cascade Ridge dome rocks having silica values of 74 to 79 


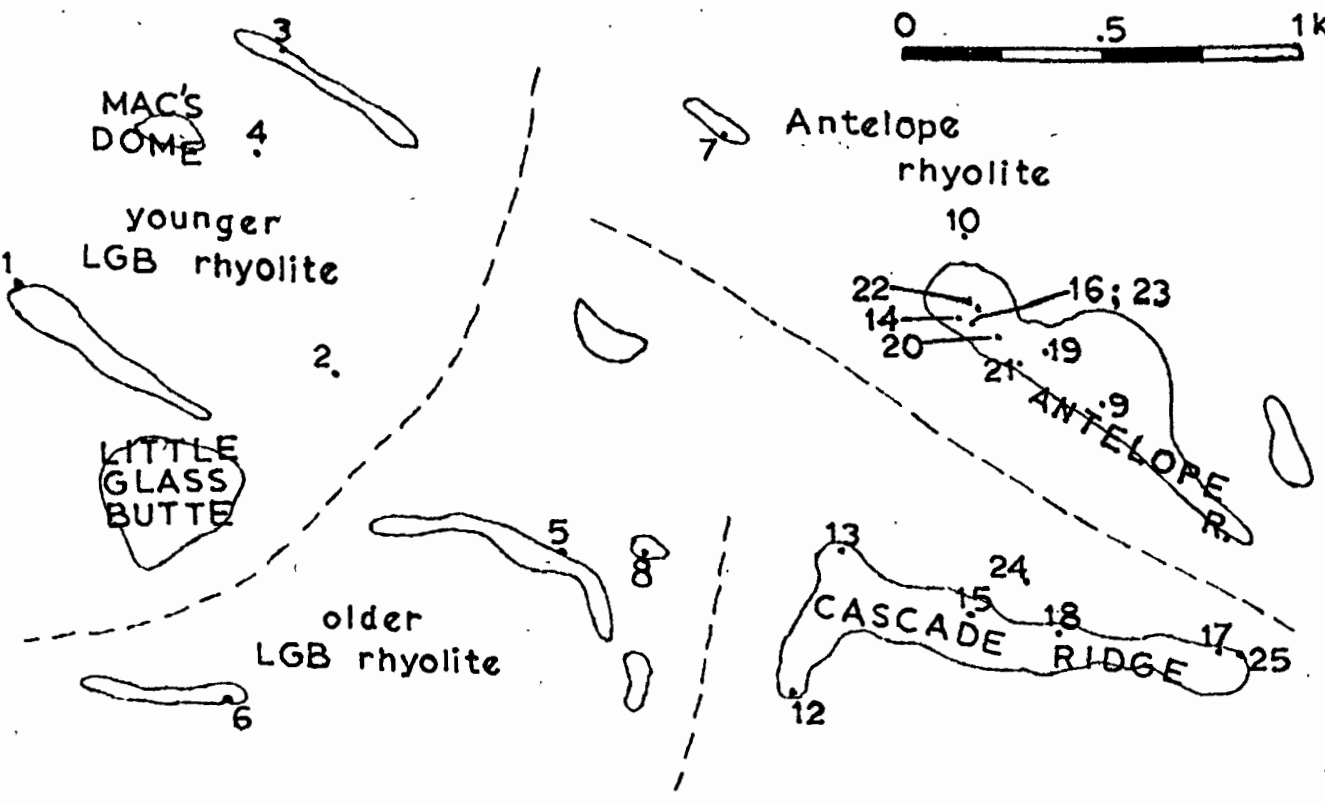

General outcrop areas, geographic names, sample locations
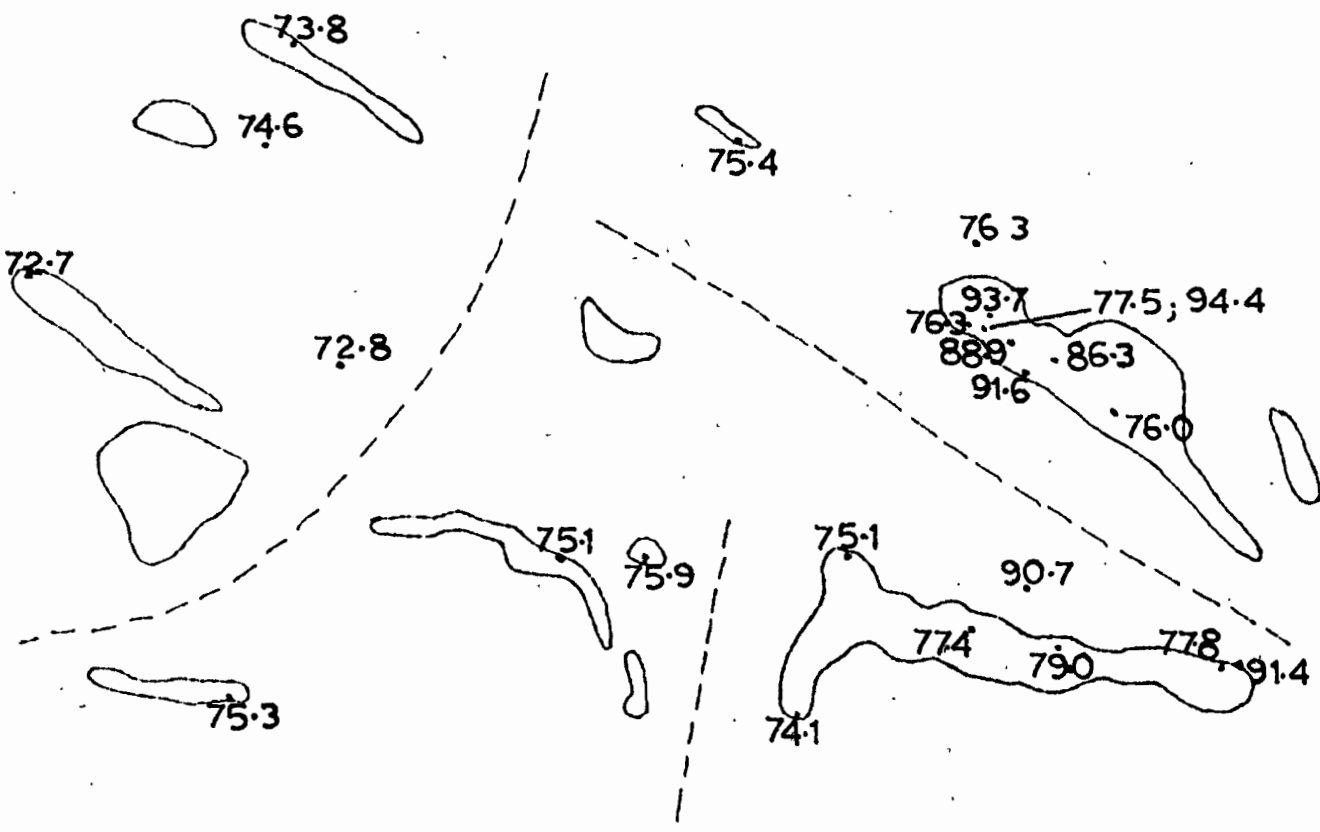

$\mathrm{SiO}_{2}$

Figure 26. Geographic distribution of major oxide abundances. 
87

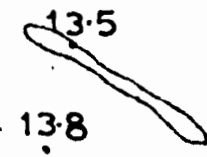

$\sqrt[140]{3}$
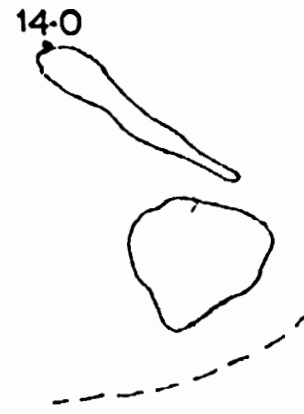

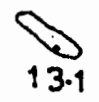

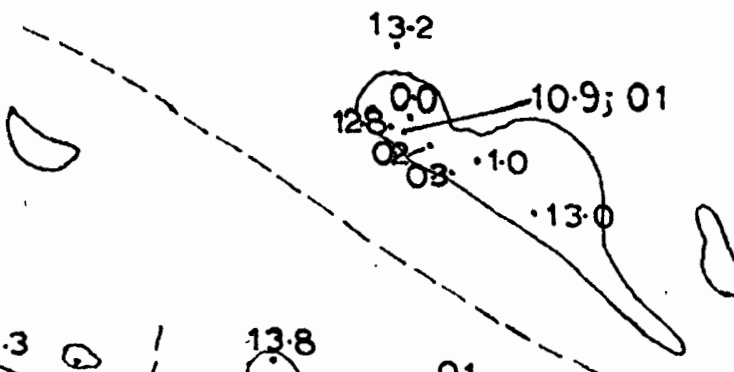

13.3.

0

12.812 .8

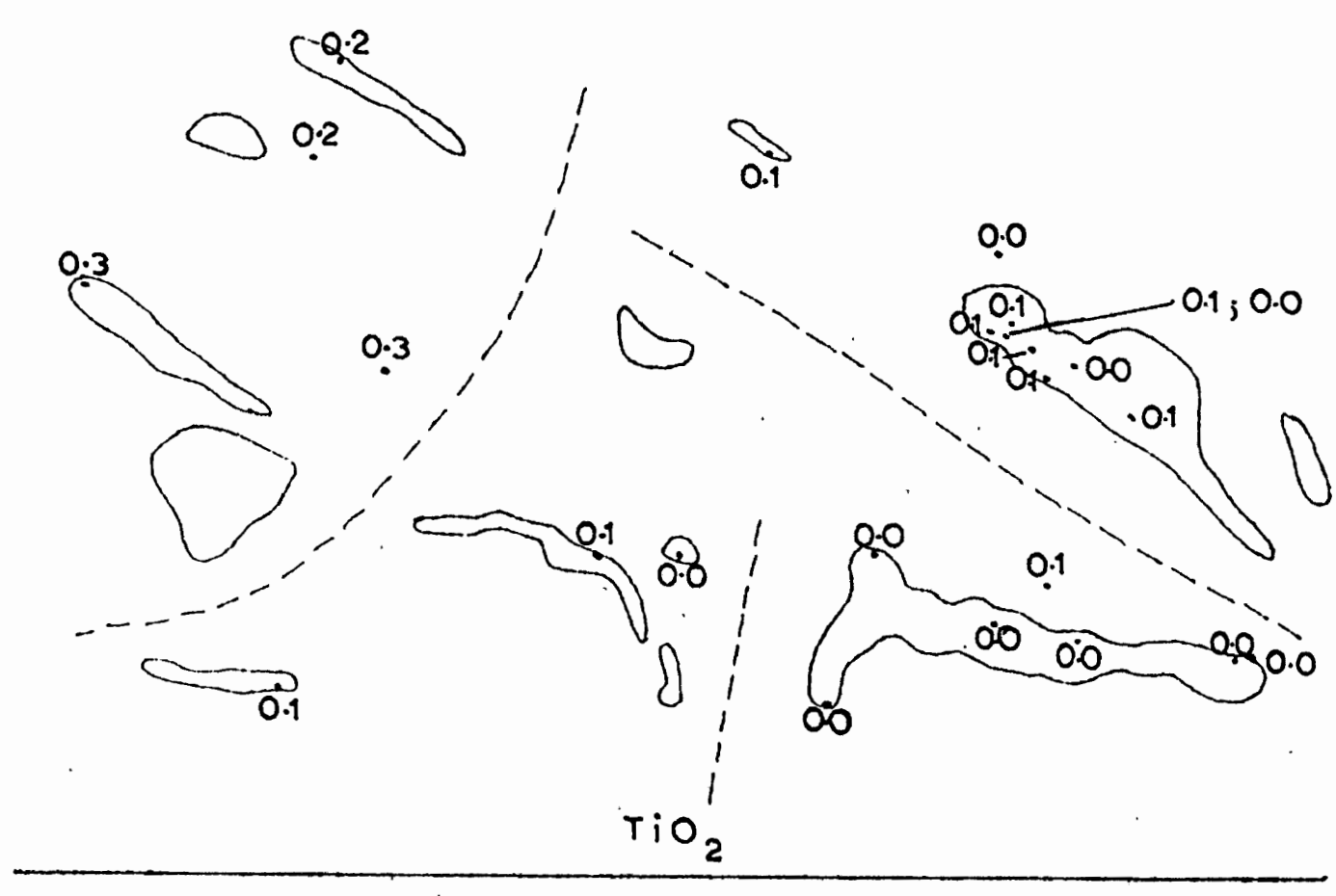

$\sqrt{0.3}$

$0: 3$

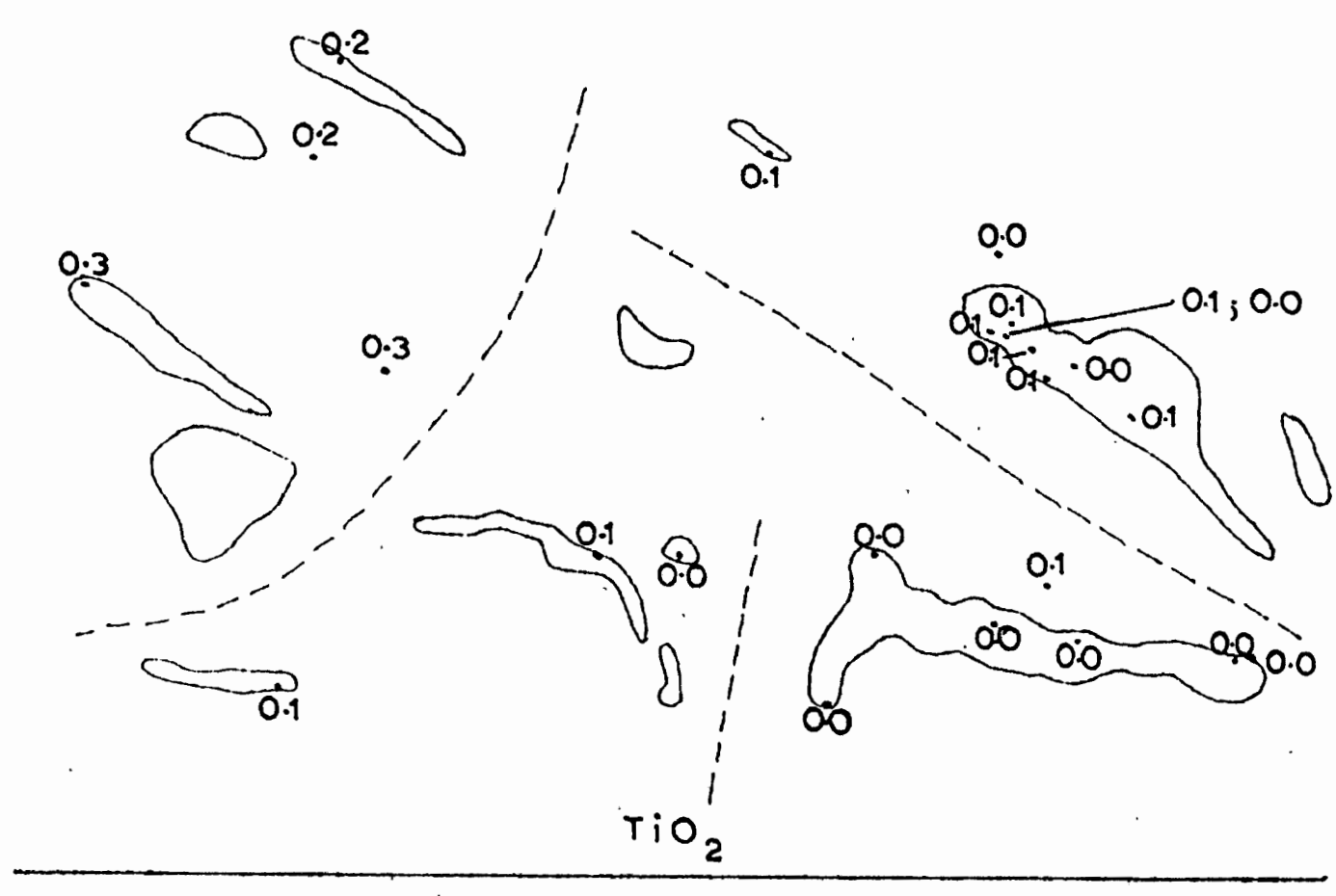

130

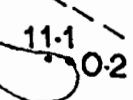

$$
\dot{A}{ }_{2} O_{3}^{\prime}
$$

Figure 26. Continued. 

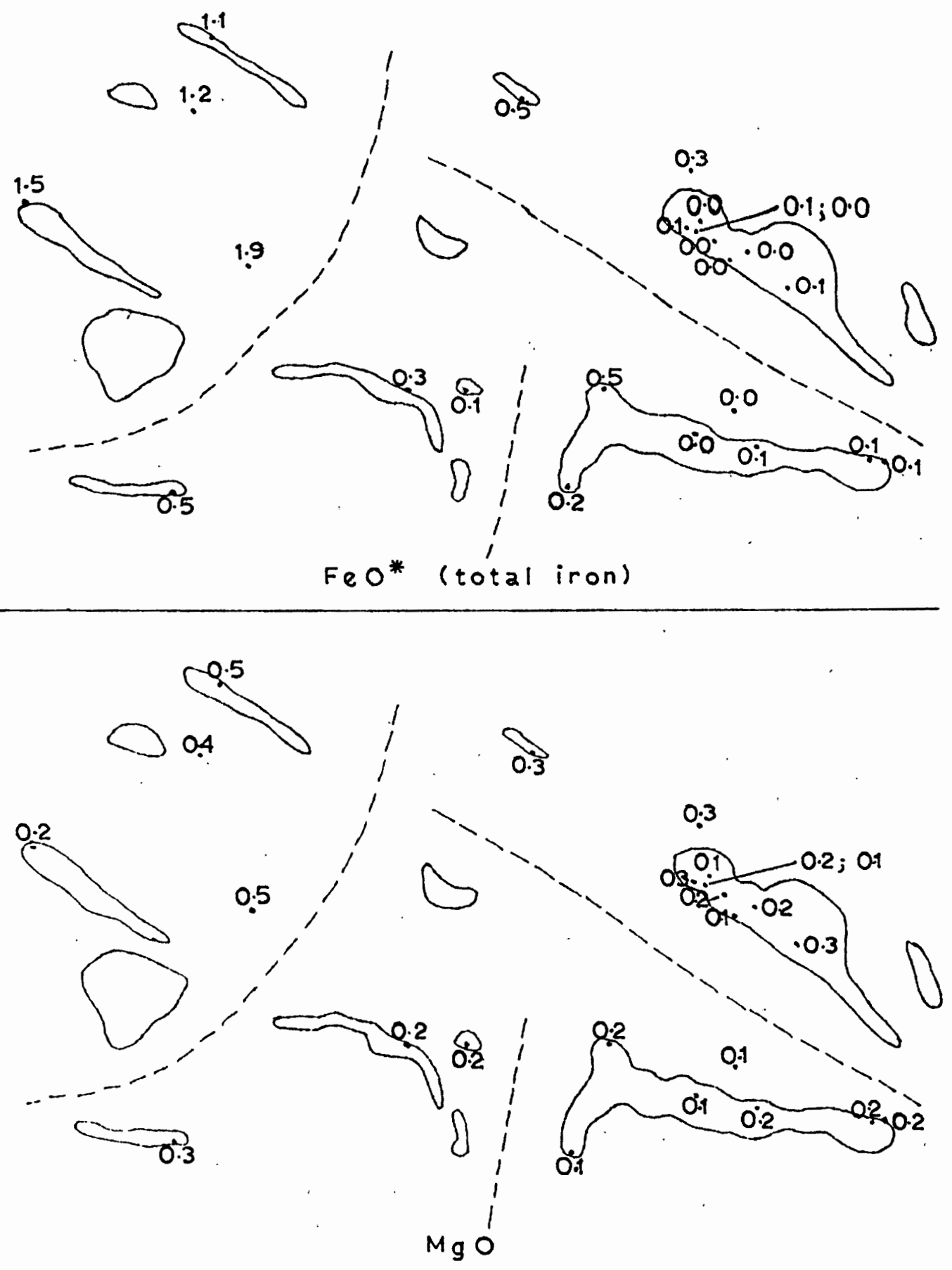

Figure 26. Continued. 

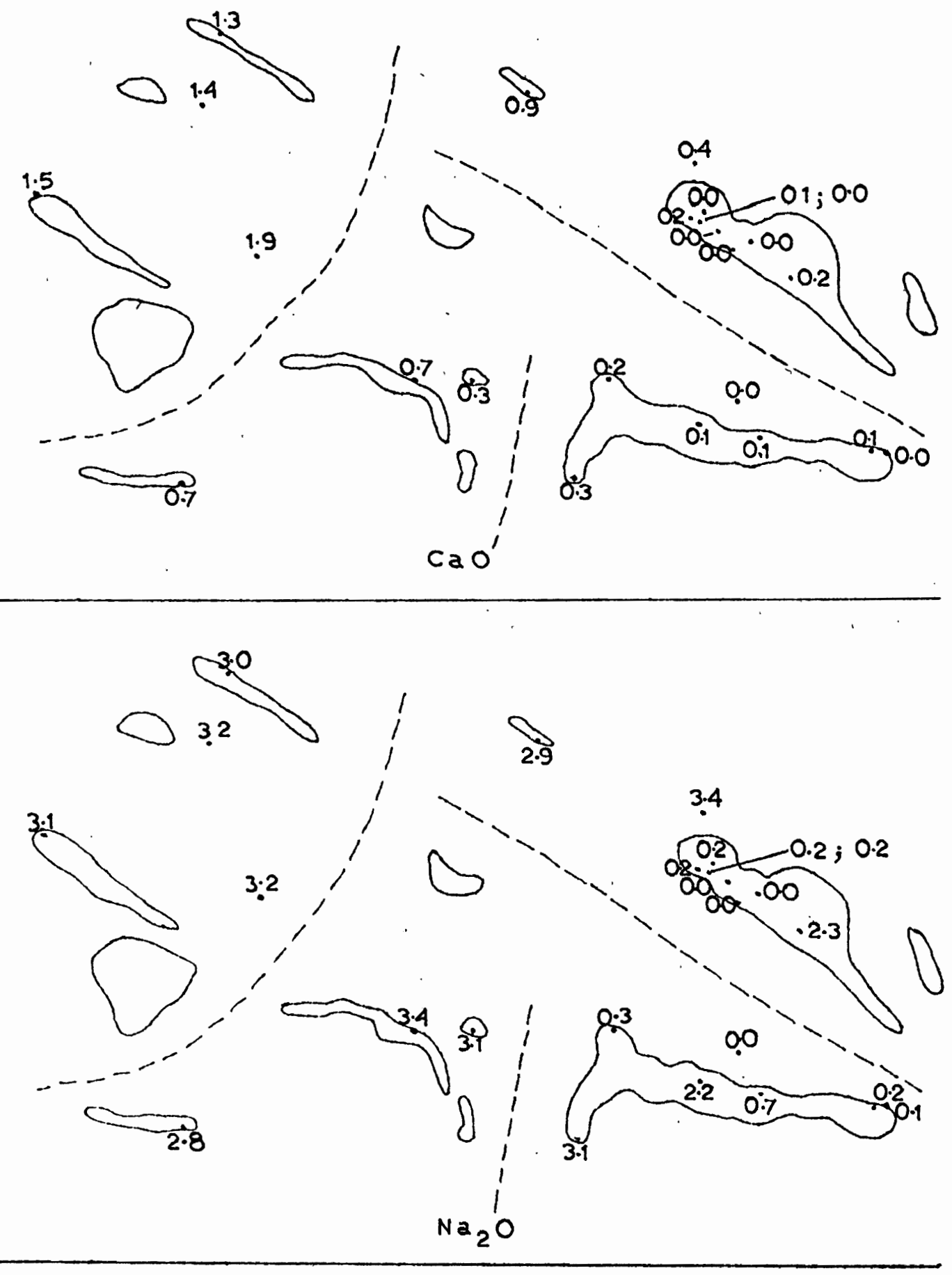

Figure 26: Continued.' 


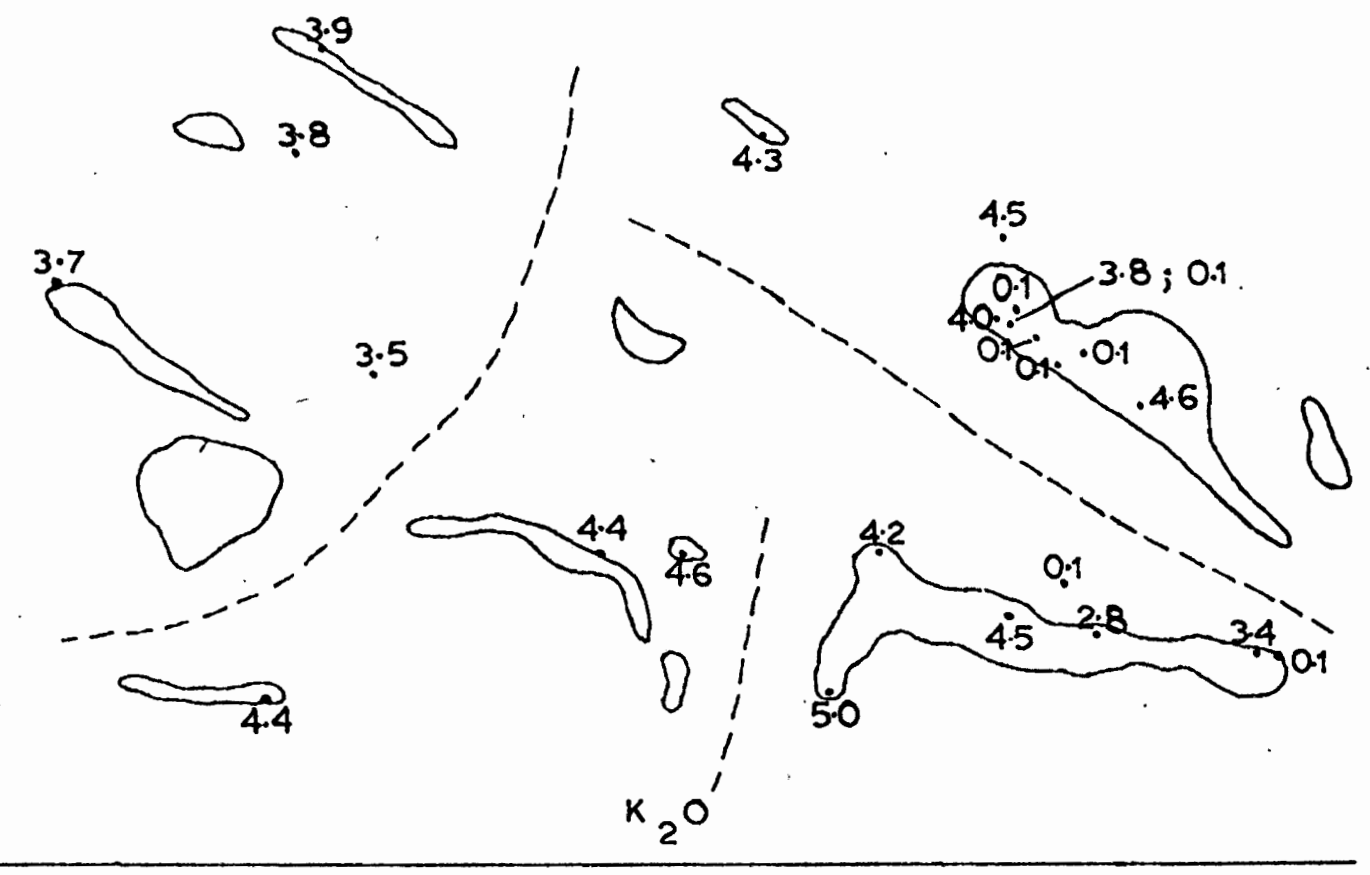

$\infty_{0.04}$

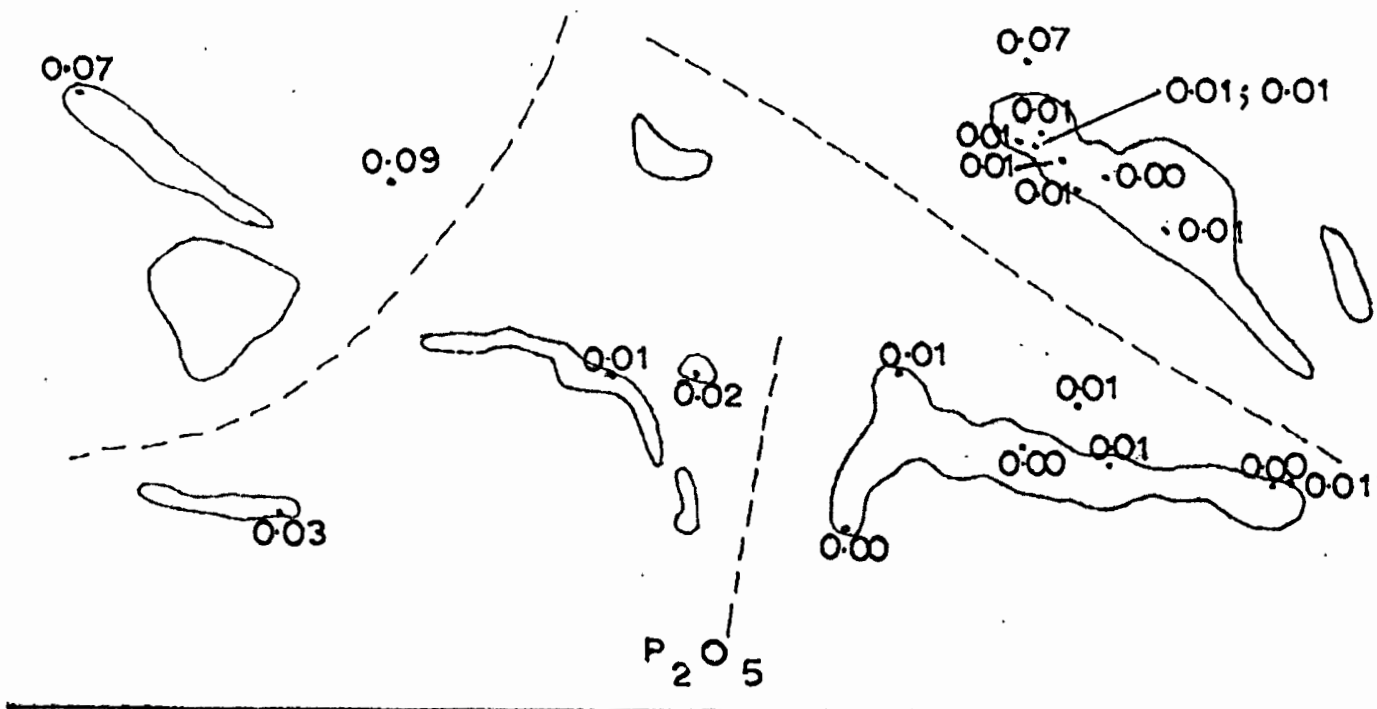

Figure 26. Continued. 


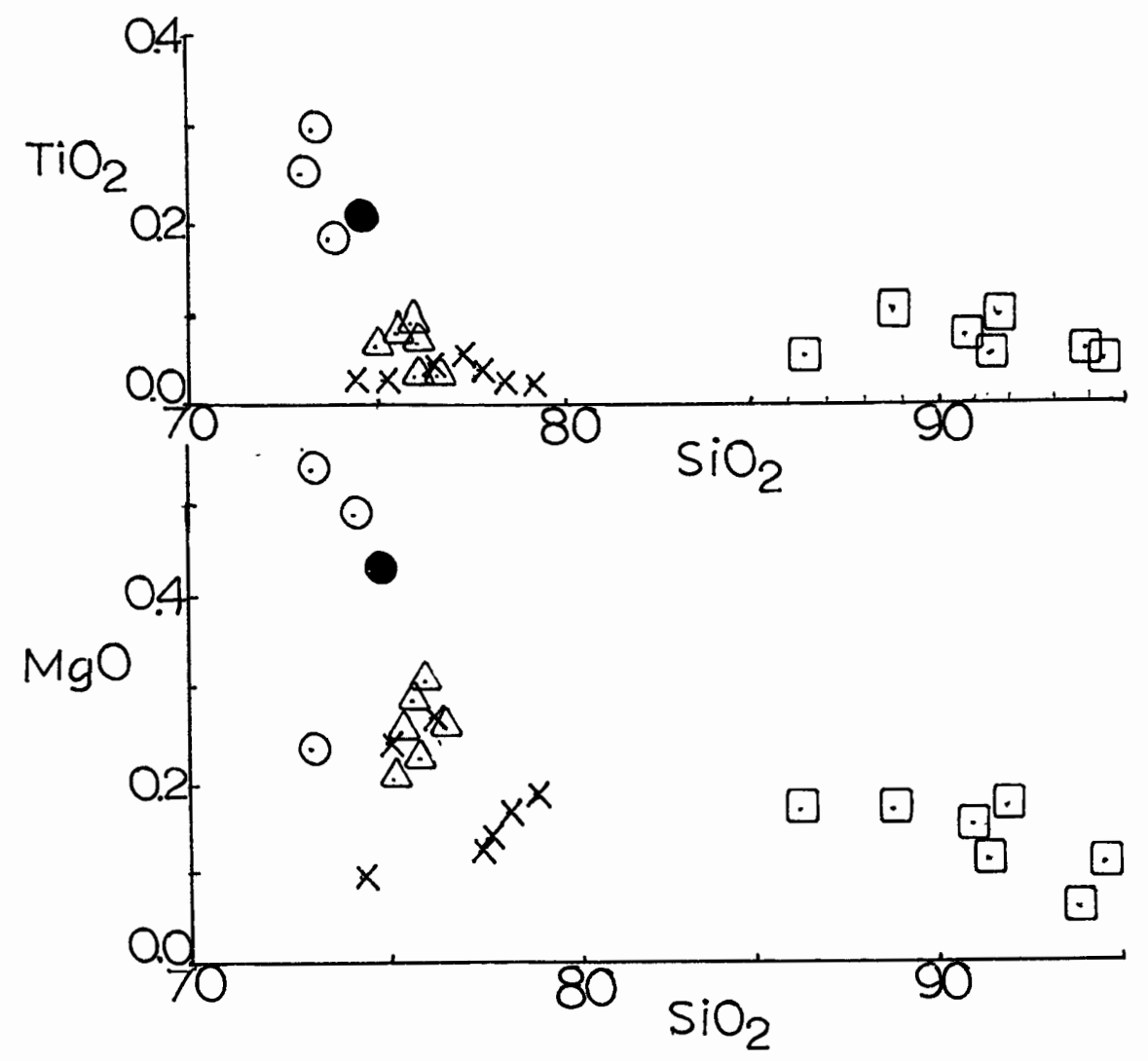

Figure 27. Variation of $\mathrm{TiO}_{2}$ and $\mathrm{MgO}$ versus $\mathrm{SiO}_{2}$, including opalized rocks, using same symbols as Figure 25 , plus squares- opalite.

percent. The dome rocks, therefore, may represent parent material to the opalite, as supported by hand-sample textural comparison of altered with unaltered rocks.

Only a moderate depletion of MgO occurred in the opalite (Fig. 27). Magnesium may have remained nearly immobile under hydrothermal alteration. Alternatively, thermal fluids leached magnesium from wall rocks, which was subsequently replaced by magnesium from descending surface water, i.e. addition of $\mathrm{MgO}$ balanced subtraction. Acid near-surface groundwaters may contain magnesium, as well as iron, calcium and aluminum, and lesser amounts of sodium and 
potassium (Rose and Burt, 1979). While downward-percolating waters might have replaced magnesium in the leached rhyolitic rocks, there has been no addition of calcium, iron or aluminum from the groundwater.

Because magnesium abundances in opalite samples are low compared to unaltered rocks, no appreciable magnesium metasomatism has occurred. Instead, minor breakdown and leaching of magnesium components in the rhyolites (biotite or hornblende) has taken place, but magnesium generally has remained immobile.

\section{Opalite Deposition}

Two different mechanisms are possible for opalite deposition, through the action of either descending or ascending fluids. In the first model, $\mathrm{H}_{2} \mathrm{~S}$ vapors rising from a boiling water table are oxidized near the surface by descending groundwater. The sulfuric acid-enriched water then seeps downward, leaching host rocks. The result is a near-surface opalite blanket, roughly conforming to the topography, that overlies a strongly argillized zone (Hulen, 1978). Such opalite blankets are described by Steiner (1953), Keller and Hanson (1968), Schoen and others (1974), Hulen (1978), and Parry and others (1980).

The nature of opolite deposits formed by sulfuric acid leaching differs from deposits at Glass Buttes. At Glass Buttes, large masses of apparently amorphous clays occur irregularly throughout the opalite, and a single occurrence 
of alunite has been identified. Formation of blankettype opalites is favored by horizontally bedded volcanic sediments, which are not found at Glass Buttes. Instead, the impermeable glassy rocks may have prohibited lateral movement of descending acid waters. The resulting opalite and argillic alteration would form steeply inclined zones, being dependent upon fault permeability.

The second model involves concentration of silica by ascending geothermal waters. Silica solubility is reduced by lowered temperatures and pressures, causing silica to precipitate near the surface. Considering rock permeability and opalite geometry at Glass Buttes, opalite was deposited from hot liquid or vapor rising along fault zones that replaced rhyolitic wall rock, although minor contributions of opalite derived from supergene processes (i.e. alteration by descending groundwater) are probable.

\section{Silica and Mercury-bearing Solutions}

Upon cooling below $80^{\circ}$ to $100^{\circ} \mathrm{C}$, solubility of silica in ascending geothermal waters is reduced and the fluid becomes supersaturated with amorphous silica (Browne, 1978), leading to precipitation of opaline silica. Cinnabar could be transported by such a fluid at temperatures from $25^{\circ}$ to $75^{\circ} \mathrm{C}$; precipitation of cinnabar in this range of temperatures is triggered by groundwater dilution or by reaction with an acidic solution (Dickson and Tunell, 1958). Cooled, diluted, 
oxidized and/or acidified hydrothermal waters, therefore, allow coprecipitation of cinnabar and silica.

White (1981) presents evidence that, in many of the mercury-depositing active geothermal areaa, mercury transport is largely in a vapor phase at temperatures as low as $35^{\circ} \mathrm{C}$, that often is accompanied by a water-saturated liquid or vapor phase that condenses and deposits silica. Because only mercury appears to be present with silica in Glass Buttes opalite, vapor is clearly the mode of transportation; temperature may have been too low for transport of other mobile elements (e.g. silver, antimony, arsenic) in solution. Cinnabar and minor hematite are the only constituents of the opalite abundant enough to be visible in hand sample. Favorable conditions of pressure and temperature for vapor transport of iron are unknown, as well as if iron persists with mercury in lower temperature vapors, while other elements precipitate. Small amounts of iron may have been carried by either the mercury vapor or by a coexisting silica-saturated water or steam, and precipitated with silica and cinnabar.

Iron and hyalite of fumarolically-altered areas represent different conditions of deposition than those of cinnabar-bearing opalite. Hematite predominates, and cinnabar, if present, is not a visible constituent. Clear amorphous silica, or hyalite, is deposited - never opalite suggesting a dry, water-free fluid carrier, or vapor. 
Fumarolic alteration, then, was achieved by leaching and decomposition of surrounding rock by a thermal vapor, followed by precipitation of iron and silica at the surface. Opalite was deposited by a lower-temperature, watersaturated liquid, accompanied by a low temperature vapor that was incapable of transporting significant iron or mobile epithermal elements other than mercury. As discussed below, iron/hyalite and cinnabar/opalite deposition may have been cyclic; one alteration type does not appear to post-date the other.

Subsurface Alteration

Drilling in the study area by Phillips Petroleum Company to depths of $600 \mathrm{~m}$ encountered relatively low temperatures. Lithologic logs are presented in Figure.28, showing zones of leached and bleached rock, brecciated rock, and occurrences of pyrite, cinnabar, opalite, hyalite and hematite. Generalized lithologic units are illustrated. Indicated intervals of unaltered glass may vary in color and degree of devitrification. Drill hole locations are given in Figure 28 and are plotted on Plate I.

Zones of leaching intersected by drilling are numerous. Skeletal, dull white to light green glass is commonly coated with granular sulfides or may contain tiny crystals of pyrite. Only in drill hole No. 1 does a fault breccia accompany this leaching, where oxidizing conditions caused hematite to precipitate from circulating fluids. 


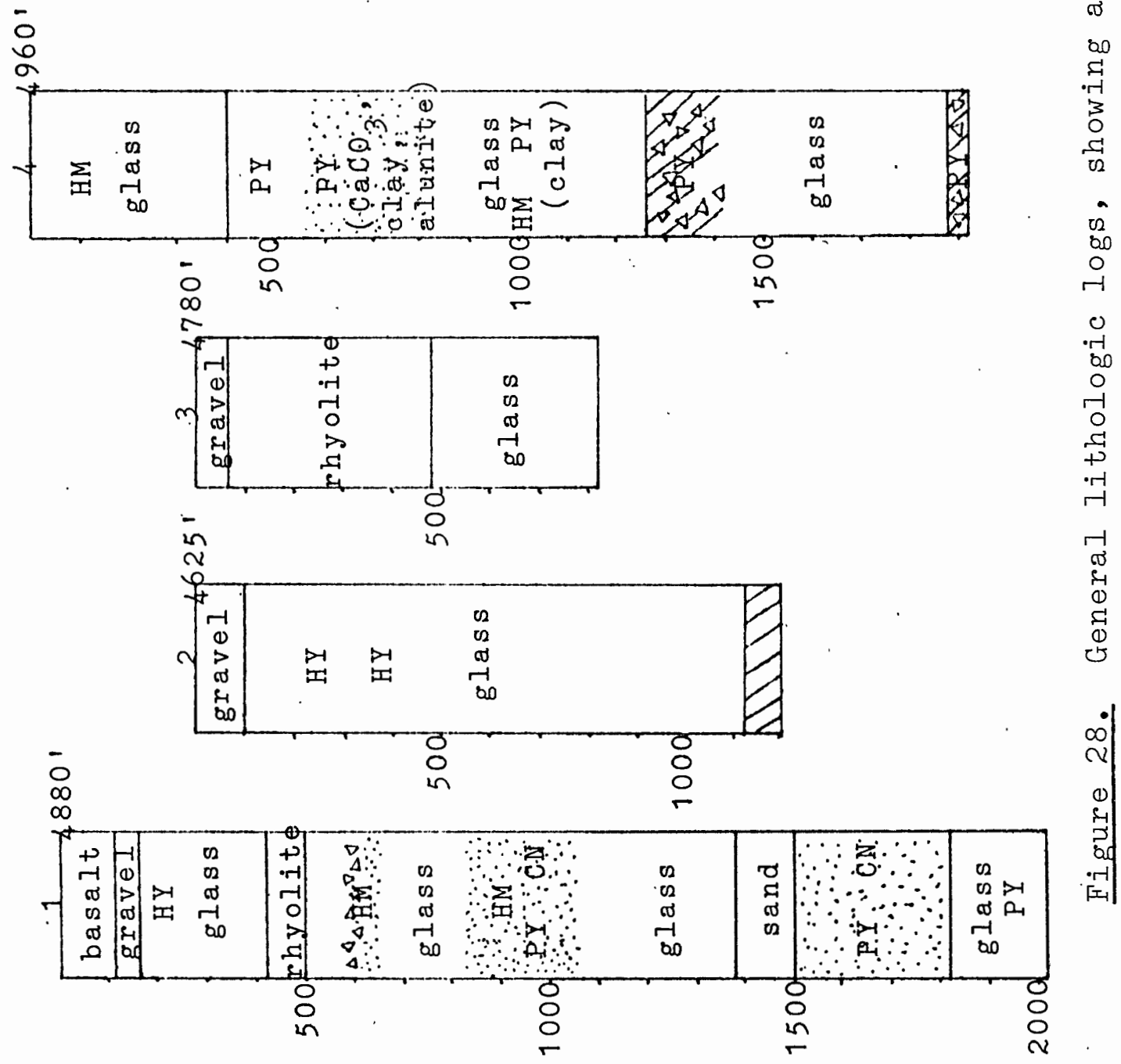


Leaching is not entirely coincident with groundwater levels existing today. Static water levels in three wells around the buttes are in the range of 141 to $155 \mathrm{~m}$ ( 462 to $509 \mathrm{ft}$ ) deep (Hull, 1976), which is considerably higher than the occurrence of leached zones in holes No. 1 and No. 4 (Fig. 28). Sulfide deposition should occur only below the water table where reducing conditions exist; while hole No. 1 shows sulfides below the leached zone, sulfides in No. 4 are above and below the zone. High temperature and/or pressurized fluids, such as vapor, attacked a permeable zone in $\mathrm{No} .4$ at áround $213 \mathrm{~m}$ (700 ft) in depth. Subsequent fauting, releasing pressure, formed a breccia zone at a depth of $384 \mathrm{~m}$ (1260 ft) in No. 4 as well as a channel for ascending silica-saturated hydrothermal fluid. If the channel sealed through deposition of silica, pressure again might have built up and renewed the cycle. This cycle of episodic boiling was used by Buchanan (1981) in modeling sixty epithermal deposits.

The opalite appearing deep in No. 2, located north of Antelope Ridge, is not brecciated at its contact with a thick overlying glass unit; instead, the contact is sharp. Another such depositional contact has already been described as occurring at the surface on Cascade Ridge, and both cases indicate eruptive activity continued after major opalization. In contrast, the two opalized zones in No. 4 are brecciated and contain pyrite at their upper contacts. These latter 
two zones may have been fault channels through which silicasaturated fluids circulated, replacing wall rock and cementing the zone with opalite.

In many cases strongly iron-oxidized contacts were observed in drill cuttings between individual glass flows, related to baking of older flows by younger flows of rhyolitic glass. Iron weathered from surface rocks and carried by surface and subsurface waters (Davis and DeWiest, 1966) may migrate in solution and be deposited along fractures (Keith and Boden, 1980), such as could develop between glass flows.

Near-surface opalite does not occur in the vicinity of the individual holes, including No. 1, situated off the northwest flank of Antelope Ridge and nearest to known surface alteration. No. 4 is located on the south-central slope of Cascade Ridge, and shows two zones of brecciated opalite at depth in the hole. The opalite, therefore, is not laterally extensive. It occurs in isolated pockets near the surface, or along steeply dipping fault zones where nearsurface conditions of temperature and pressure temporarily existed.

The results of these four drill holes indicate several features of the hydrothermal system. The system is complex and involves more than simple near-surface deposition of opalite and cinnabar. Where structures are not present to release hydrothermal fluids to the surface, pressurized vapors etched and disintegrated rhyolitic glass. If country 
rock is faulted, the pressure release causes boiling and cooling, and formation of opalite at depth.

Leached zones represent high permeability that allowed vapor or liquid to penetrate. This could have resulted from faulting, or intersection of faults with permeable units such as flow breccia or sediments that allowed local lateral alteration. Some supergene acid leaching, described earlier, may have occurred above the groundwater table and contributed to permeability. Therefore; some combination of faults,... formational permeability and groundwater pathways that may have varied in level through time, led to formation of zones of leaching. 


\section{ECONOMIC ASPECTS OF GLASS BUTTES}

\section{CINNABAR DEPOSITS}

Mercury mineralization was discovered in 1933, and production peaked in 1957 when 1300 tons of ore yielded 87 flasks of quicksilver (Brooks, 1971). Since that time, mining has ceased due to poor economic returns. Claims are, however, still held active.

Underground workings include several tunnels and shafts on western Antelope Ridge, as well as eastern Cascade Ridge (see Fig. 24). Opencuts and trenches are abundant throughout the entire eastern portion of the study area, and greatly increase the amount of rock exposed for inspection. Native mercury has not been noted and cinnabar concentrated in brecciated opalite averages less than 3 pounds of mercury per ton (Brooks, 1963).

Nearby mercury deposits include the Ochoco Quicksilver District (Schuette, 1938), east of Prineville and northnortheast of Glass Buttes, that lies along northwest or northeast-trending faults, and, although silicification is extensive, no massive opalite is associated with the cinna-t. bar. The Opalite Quicksilver District (Schuette, 1938) includes the McDermitt, Bretz and Opalite mines in the McDermitt area on the southeast Oregon-Nevada border, where 
cinnabar is localized in tuffaceous sediments. Faultcontrolled hot springs deposited massive opaline sinter. Brecciation of the opalite was followed by another surge of cinnabar-bearing silica-rich fluid (Rytuba and Glanzman, 1979). While the Glass Buttes mines belong in the Opalite District, probably no hot spring sinter was deposited there, but instead large amounts of silica-rich fluid replaced wall rock and cemented fault zones.

Due to the volatile nature of mercury, most, if not all mercury in the hydrothermal system was transported to the near-surface where it precipitated with silica. The potential, then, for economic grades of cinnabar or native mercury deposits existing beneath the opalite is insignificant.

\section{GEOTHERMAL EXPLORATION}

Exploration of volcanic features subparallel to the Brothers fault zone led geothermal investigators to the younger, west end of the volcanic zone, where testing of drill holes at Newberry caldera recently indicated a temperature gradient of $285^{\circ} \mathrm{C} / \mathrm{km}$ (anonymous, 1981a; anonymous, 1981b). Eastward along the zone of silicic centers, progressively older volcanic rocks are found, with a corre-", sponding decrease in geothermal potential (Walker, 1974). Exploration in these areas has been limited.

Alteration and cinnabar deposits at Glass Buttes encouraged geothermal exploration. Studies have been 
conducted from 1975 to the present, including resistivity (Hull, 1976) and geochemical surveys, mapping and drilling. Phillips Petroleum Company drilled four deep stratigraphic test holes around the eastern Glass Buttes and the Oregon Department of Geology and Mineral Industries has drilled temperature gradient holes in the area (see Bowen, 1975; Hull and others, 1975; Bowen and others, 1977).

Heat flow, the product of geothermal gradient and rock conductivity, is anomalous at Glass Buttes; 4.6 Heat Flow Units (Bowen and others, 1977), which is more than twice the average for the Basin and Range Propovince. The source of heat most likely is a cooling igneous body at depth beneath the buttes; radiogenic heat may also be a contributing factor. The anomaly diminishes rapidy away from the areas of alteration. About $9 \mathrm{~km}$ west of Antelope Ridge, between Little Glass Butte and Glass Butte, heat flow has been measured at $2.9 \mathrm{HFU}$, and $7 \mathrm{~km}$ farther southwest is $1.8 \mathrm{HFU}$ (Bowen and others, 1977).

The heat flow anomaly is centered near the west end of Antelope Ridge where a temperature of $48^{\circ} \mathrm{C}$ was measured at a depth of $220 \mathrm{~m}$ in a water well (Bowen and others, 1977). This well is near the mining pits on Antelope Ridge that show extensive alteration. Temperature gradients measured nearby were $144^{\circ} \mathrm{C} / \mathrm{km}$ and $120^{\circ} \mathrm{C} / \mathrm{km}$ (Justus, 1979).

The presence of a layer at depth having low electrical resistivity, capped by a more impermeable layer (hull, 1976), suggests deep circulating, heated groundwater exists, 
producing the heat flow anomaly. The age of the complex (around $5 \mathrm{~m} . \mathrm{y}$. , Walker, 1974) is, however, relatively old compared to active geothermal areas where volcanism occurred less than one million years ago, e.g. the Geysers; New Zealand; Steamboat Springs, Nevada, and Roosevelt Hot Springs, Utah.

\section{MODEL OF THE GEOTHERMAL RESERVOIR}

From the data presented, the geothermal system at Glass Buttes probably extends to depths over $600 \mathrm{~m}$, as indicated by 1) a lack of ash-flow deposits and no evidence of caldera collapse, as expected in a relatively shallowseated magma reservoir, and 2) the presence of opalite in drill holes as deep as $550 \mathrm{~m}$ (see Fig. 28). If leached zones and opalite observed in drill holes represent leaks from a deeper system, then much deeper drilling (over $600 \mathrm{~m}$ ) may be required to reach the actual geothermal reservoir. This assumes there is still a heat source at Glass Buttes; high heat flow and warm water wells suggest this is true. The resistivity study conducted in the area shows a high resistivity cap rock, probably glassy rhyolitic lavas, about $200 \mathrm{~m}$ thick in the eastern buttes. This cap overlies a more permeable layer of unknown thickness, represented by opalized and leached zones in the lower half of holes No. 1 and 4 (see Fig. 28). The capping rhyolite may insulate the system, preventing loss of fluids and heat. The silicasaturated fluids or vapors inferred to have been part of the 
geothermal system at Glass Buttes would also have plugged whatever fracture permeability that existed, and prevented the ascent of solutions.

Lack of surface phenomena such as hot springs or active fumaroles indicate either the system has cooled or that the opalite deposits have plugged all avenues of leakage. In the first case, depths to useable hot water should be ecanomically prohibitive. In the latter case, it is possible that a viable geothermal reservoir exists beneath the opalite. Leakage from the system has been only in isolated areas along major northwest-trending faults, i.e. the Antelope and Cascade Ridge faults, and also at fault intersections, i.e. Cascade mine, east Cascade Ridge. Due to the vertical nature of the faults, deep drilling very close to, or within, areas of surface alteration might reach the primary aquifer, but drilling to date has not revealed its existence.

Because of the relative coolness or great depth of the hydrothermal system, exploration efforts might best be directed toward precious metals associated with mercury. A gold-dominated deposit may be trapped below the impermeable surface layer, not transported by vapor to the surface. Arsenic and antimony, as well as mercury, as associated with such deposits, while base metal sulfides are lacking (Levinson, 1974; White, 1981). Such a concealed system is suggested by large amounts of silica containing highly mobile epithermal ores such as mercury, appearing only in leaks (White, 1981). 
The model proposed by Buchanan (19f8) for epithermal systems should be investigated, in which periodic fracturing permits boiling of the hydrothermal fluids, development of fumaroles at the surface, and deposition of base and precious metals at great depths. Boiling is followed by resealing and pressurizing of the system, relieved by subsequent fracturing and boiling. This model is suggested by the high pressure etching found overlying low temperature opalite in hole No. 4 at Glass Buttes, described earlier. The precious metals horizon may, however, be at substantially greater depths. 


\section{SUMMARY AND CONCLUSIONS}

The Glass Buttes volcanic complex in:southeast Oregon consists of many domes and individual vents that erupted both rhyolitic and basaltic lavas during the late Miocene to early Pliocene. The major volcanic feature in the east half of the complex is Little Glass Butte, where interfingering rhyolite and obsidian flows are present. The youngest unit here, an obsidian, has been dated at $4.9 \mathrm{~m} \cdot \mathrm{y}$. East of Little Glass Butte lie two northwest-trending ridges, Antelope and Cascade Ridges, composed of two or more exogenous domes that formed along northwest-trending faults.

Dome-related rhyolitic rocks include flanking flowbanded glass and viscous perlitic glass flows, while at the crest are found blocky pumice breccias and glassy flowbreccia. Frothy, inflated dome rocks show strong depletions in $\mathrm{Na}_{2} \mathrm{O}$ because of greater susceptibility to hydration and groundwater leaching. Vapor-phase crystallization has sig: nificantly enriched silica contents.

Vent-related rhyolite and obsidian flows probably erupted from near Iittle Glass Butte. The rhyolites are nearly aphyric, and the older of the units is thoroughly devitrified by growth of spherulites. Obsidian units are black aphyric flows, often showing remixing of oxidized surface glass during flow, as well as thin layers of grey, 
hydrated glass (perlite). Less secondary chemical alteration occurred, compared to the dome rocks.

Coarsely feldspathic basalt interfingers with rhyolitic units, and originated from fissures or vents within the buttes. Finer-grained olivine basalt covers the plateau surrounding the complex. Its age relative to silicic volcanism is unclear.

Glass Buttes lies at the intersection of the northwesttrending Brothers fault zone with a west-northwest-trending silicic volcanic zone. Major faults in the buttes follow these trends, and northeast-trending joints are expressions of fracturing conjugate to the regional trends. Rapid eruption of glassy rhyolite and mafic lavas occurred as well as development of a heat source at depth that fostered a hydrothermal system.

The Glass Butte mine fault and the Cascade Ridge fault are northwest-trending, curving fault'zones with variable dips. Possible evidence of strike-slip motion was observed on the Cascade Ridge fault. The curving fault planes served as impermeable barriers to rising cinnabar-bearing fluids. Hydrothermal alteration was concentrated along faults and involved silicification and advanced argiliic alteration of wall rocks by silica-saturated fluids. Opalite forms vertically elongated masses within fault zones as deep as $600 \mathrm{~m}$, or isolated pockets near the surface. Rising hydrothermal fluids replaced wall rock and upon cooling precipitated amorphous hydrous silica that sealed fault breccia. 
Lack of other metals in the opalite suggest the fluid was a water-saturated liquid, accompanied by a vapor as low as $35^{\circ} \mathrm{C}$ capable of transporting only the relatively volatile mercury and minor iron.

Drill hole data show zones of leaching and etching, higher in elevation than presumably lower-temperature opalite. Pressurized fluids etched slightly permeable rock layers, and, when faults released pressure on the system, opalite formed under lower temperature and pressure from water- and silica-saturated fluids, effectively resealing the system. This cycle of alteration probably repeated many times.

Volcanism and faulting occurred during and after the main alteration event. Faulting that relieved pressure build-up in the hydrothermal system also provided conduits for magma to reach the surface. Continued volcanism may have partially sealed the hydrothermal system. Fumaroles vented through rhyolitic glass that overlies opalite. Sites of fumarolic activity may be related to faults developed after the main period of surface opalization ceased. Hydrothermal alteration was not a recent geologic event at Glass Buttes. Lacking surface deposits and active surface phenomena, at best only a very deep heat source remains. High heat flow in the area may be due to heated, deep-circulating groundwater. Steeply inclined zones of hydrothermal alteration and recurrent fracturing are evidence 
of a deep system at Glass Buttes, below that of presently drilled depths, that may contain economic precious metal deposits. 


\section{BIBLIOGRAPHY}

Anonymous, 1981a, Newberry well is hottest geothermal prospect yet reported in Oregon: Oregon Geology, v. $43, \mathrm{p} .126$.

Anonymous, 1981b, Test of Oregon's hottest geothermal well confirms a substantial resource: Oregon Geology, v. $43, \mathrm{p} .153$.

Bacon, C. R., 1982, Time-predictable bimodal volcanism in the Coso Range, California: Geology, v. 10, p. 65-69.

Bacon, C. R., and Duffield, W. A., 1980, Distribution of Quaternary rhyolite domes of the Coso Range, California: Implications for extent of the geothermal anomaly: Jour. Geophysical Res., v. 85, p. 2425-2433.

Barnes, H. L., 1979, Solubilities of ore minerals, in Barnes, H. L., ed., Geochemistry of hydrothermal ore deposits, 2d ed.: New York, John Wiley and Sons, p. $404-460$.

Barth, T. F. W., 1962, Theoretical petrology, 2d ed.: New York, John Wiley and Sons, $416 \mathrm{p}$.

Bayly, B., 1968, Introduction to petrology: New Jersey, Prentice-Hall, $371 \mathrm{p}$.

Beeson, M. H., 1969, A trace element study of silicic volcanic rocks: San Diego, University of California, unpublished Doctoral thesis, $130 \mathrm{p}$.

Billings, M. P., 1942, Structural geology: New York, Prentice-Hall, $473 \mathrm{p}$.

Bishop, E. E., Eckel, E. B., and others, 1978, Suggestions to authors of the reports to the United States Geological Survey: Washington, D. C., U. S. Government Printing Office, $273 \mathrm{p}$.

Bowen, R. G., 1975, Geothermal gradient data: Oregon Dept. Geol. Min. Ind. Open File Report 0-75-3, $30 \mathrm{p}$. 
Bowen, R. G., Blackwell, D. D., Hull, D. A., and Peterson, N. V., 1976, Progress report on heat-flow study of the Brothers fault zone, central Oregon: Ore Bin, v. 38 , no. 3, p. 39 .

Bowen, R. G., Blackwell, D. D., and Hull, D. A., 1977, Geothermal exploration studies in Oregon: Oregon Dept. Geol. Min. Ind. Misc. Paper 19, $50 \mathrm{p}$.

Boyd, F. R., 1961, Welded tuffs and flows in the rhyolite plateau of Yellowstone Park, Wyoming: Geol. Soc.

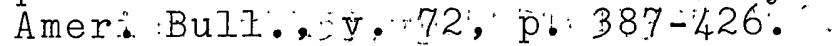

Brooks, H. C., 1963, Quicksilver in Oregon: Oregon Dept. Geol. Min. Ind. Bull. 55, p. 171-175.

Brooks, H. C., 1971, Quicksilver deposits in Oregon: Oregon Dept. Geol. Min. Ind. Misc. Paper 15.

Browne, P. R. L., 1970, Hydrothermal alteration as an aid in investigating geothermal fields: Geothermics, Special Issue 2, p. 564-570.

1978, Hydrothermal alteration in active geothermal fields: Ann. Rev. Earth Plan. Sci., v. 6, p. 229-250.

Browne, P. R. L., and Ellis, A. J., 1970, The OhakiBroadlands hydrothermal area, New Zealand: Mineralogy and related geochemistry: Amer. Jour. Sci., v. 269, p. 97-131.

Brownlow, A. H., 1979, Geochemistry: New Jersey, PrenticeHall, $498 \mathrm{p}$.

Buchanan, L. J., 1981, Precious metal deposits associated with volcanic environments in the Southwest, in

Dickenson, W.R., and Payne, W.D., eds., Relations of tectonics to ore deposits in the southern Cordillera: Arizona Geol. Soc. Digest, v. 14, p. 237-255.

Carroll, D., 1970, Clay minerals: A guide to their X-ray identification: Geol. Soc. Amer. Spec. Paper 126, $80 \mathrm{p}$.

Dake, H. C., 1956, Obsidian carvings: Mineralogist, v. 24, no. 12, p. $474-476$.

1958, Glass Buttes, Oregon: Mineralogist, v. 26, no. 12, p. 330 .

1959, Glass Buttes, Oregon: Mineralogist, v. 27 , no. 1, p. 332-333. 
Davis, S. N., and DeWiest, R. J. M., 1966, Hydrogeology: New York, John Wiley and Sons, 463 p.

Dicken, S. N., 1965, Oregon geography, 4th ed.: Michigan, Edwards Brothers, 127 p.

Dickson, F. W., 1966, Solubilities of metallic sulfides and quartz in hydrothermal sulfide solutions: Bull. Volcan., v. 29, p. 605-628.

Dickson, F. W., and Tunell, G., 1958, Equilibria of red HgS(cinnabar) and black HgS(metacinnabar) and their saturated solutions in the systems $\mathrm{HgS}-\mathrm{NaS}_{-} \mathrm{H}_{2} \mathrm{O}$ and $\mathrm{HgiS}-\mathrm{Na}_{2} \mathrm{~S}-\mathrm{Na}_{2} \mathrm{O}-\mathrm{H}_{2} \mathrm{O}$ from $25 \mathrm{C}$ to $75 \mathrm{C}$ at 1 atmosphere pressure: Amer. ${ }^{2}$ Jour. Sci., v. 256, p. 654-679.

Duffield, W. A., Bacon, C. R., and Dalrymple, G. B., 1980, Late Cenozoic volcanism, geochronology, and structure of the Coso Range, Inyo County, California: Jour. Geophysical Res., v. 85, p. 2381-2404.

Ewart, A., 1971, Chemical changes accompanying spherulitic crystallization in rhyolitic lavas, Central Volcanic Region, New Zealand: Mineral. Mag., v. 38, p. 424-434.

Finlow-Bates, T., and Stumpfl, E. F., 1981, The behavior of so-called immobile elements in hydrothermally altered rocks associated with volcanogenic submarineexhalitive ore deposits: Mineralium Deposita, v. 16, p. 319-328.

Fleischer, M., 1970, Summary of the literature on the inorganic geochemistry of mercury: U. S. Geol. Survey Prof. Paper 713, p. 6-13.

Fournier, R. O., and Rowe, J. J., 1966a, Estimation of underground temperatures from the silica content of water from hot springs and wet-steam wells: Amer. Jour. Sci., v. 264, p. 685-697.

Fournier, R. 0., and Rowe, J. J., 1966b, The deposition of silica in hot springs: Bull. Volcan., v. 29, p. 585588 .

Greene, R. C., Walker, G. W., and Corcoran, R. E., 1972, Geologic map of the Burns quadrangle, Oregon: U. S. Geol. Survey Misc. Geol. Invest. Map I-680, scale $1: 250,000$.

Groh, E. A., 1966, Geothermal energy potential in Oregon: Ore Bin, v. 28, p. 125-135. 
Guth, L. R., Bruhn, R. L., and Beck, S. L., 1981, Fault and joint geometry at Raft.River geothermal area, Idaho: Salt Lake City, University of Utah, 19 p.

Heflin, E., 1963, Oregon's Glass Buttes: Prehistoric munitions factories: Lapidary Jour., v. 17, no. 8, p. 818821 .

Hem, J., 1970, Chemical behavior of mercury in aqueous media: U. S. Geol. Survey Prof. Paper 713, p. 19-24.

Higgins, M. W., 1973, Petrology of Newberry Volcano, central Oregon: Geol. Soc. Amer. Bull. 84, p. 455-488.

Hobbs, B. E., Means, W. D., and Williams, P. F., 1976, An outline of structural geology: New York, John Wiley and Sons, $571 \mathrm{p}$.

Holland, H. D., and Malinin, S. D., 1979, The solubility and occurrence of non-ore minerals, in Barnes, H. L., ed., Geochemistry of hydrothermal ore deposits, $2 \mathrm{~d}$ ed.: New York, John Wiley and Sons, p. 465-471.

Hulen, J. B., 1978, Geology and alteration of the Coso geothermal area, Inyo County, California: Salt Lake City, University of Utah, $28 \mathrm{p}$.

Hull, D. A., 1976, Electrical resistivity survey and evaluation of the Glass Buttes geothermal anomaly, Lake County, Oregon: Oregon Dept. Geol. Min. Ind. Open File Report 0-76-1, $18 \mathrm{p}$.

Hull, D. A., Bowen, R. G., Blackwell, D. D., and Petersion, N. V., 1975, Geothermal gradient data, Brothers fault zone, Oregon: Oregon Dept. Geol. Min. Ind. Open File Report 0-76-2, $99 \mathrm{p}$.

Jack, R. N., and Carmichael, I. S. E., 1969, Chemical "fingerprinting" of acid volcanic rocks: Calif. Div. Mines and Geol. Spec. Report 100, p. 17-32.

Justus, D., 1979, Geothermal energy in Oregon: Site data base and development status: Klamath Falls, Oregon Inst. of Tech., Geo-Heat Utilization Center, 438 p.

Keith, T. E. C., and Boden, J. R., 1980, Volcanic stratigraphy and alteration mineralogy of drill cuttings from EWEB 4 drill hole, Clackamas County, Oregon: U. S. Geol. Survey Open File Report 80-891, 8 p. 
Keller, W. D., and Hanson, R. F., 1968, Hydrothermal alteration of a rhyolite flow breccia near San Luis Potosi, Mexico, to refractory kaolin: Clays and Clay Min., v. 16, p. 223-229.

Kirkbright, G. F., and Sargent, M., 1974, Atomic absorption and fluorescence spectroscopy: San Francisco, Academic Press, $798 \mathrm{p}$.

Krauskopf, K. B., 1979, Introduction to geochemistry, 2d ed.: San Francisco, McGraw-Hill, $617 \mathrm{p}$.

Langmyhr, F. J., and Paus, P. E., 1968, Analysis of inorganic siliceous materials by atomic absorption spectrophotometry and the hydrofluoric acid decomposition technique: Anal. Chim. Acta, v. 43, Part I, p. 397408; Part VIII, p. 515-516.

Lawrence, R. D., 1976, Strike-slip faulting terminates the Basin and Range province in Oregon: Geol. Soc. Amer. Bull., v. 87, p. 846-850.

Levinson, A. A., 1974, Introduction to exploration geochemistry, 2d ed.: Illinois, Applied Publishing, $924 \mathrm{p}$.

Lipman, P. W., 1965, Chemical comparison of glassy and crystalline volcanic rocks: U. S. Geol. Survey Bull. 1201D, p. D1-D24.

1975, Evolution of Platoro caldera, San Juan Mountains, Colorado: U. S. Geol. Survey Prof. Paper 852, $128 \mathrm{p}$.

Lowrie, W., and Alvarez, W., 1981, One hundred million years of geomagnetic polarity history: Geology, v. 9, p. 392-397.

MacLeod, N. S., Walker, G. W., and McKee, E. H., 1976, Geothermal significance of eastward increase in age of upper Cenozoic rhyolitic domes in southeastern Oregon, in United Nations Symposium on the development and use of geothermal resources, 2d, San Francisco, 1975, Proceedings: v. $1, \mathrm{p} \cdot 465-474$.

Mayo, E. B., 1944, Rhyolite near Big Pine, California: Geol. Soc. Amer. Bull., v. 55, p. 599-620.

McKinstry, H. E., 1955, Structure of hydrothermal ore deposits: Econ. Geol., Fiftieth Anniversary Vol., 1905$1955 ; \mathrm{p} \cdot 170-225$. 
Meyer, C. C., and Hemley, J. J., 1967, Wall rock alteration, in Barnes, H. L., ed., Geochemistry of hydrothermal ore deposits: New York, Holt, Rinehart and Winston, p. 166-235.

Noble, D. C., 1965, Groundwater leaching of sodium from quickly cooled volcanic rocks: Amer. Mineral., v. 50, p. 289 .

1967, Sodium, potassium, and ferrous iron contents of some secondarily hydrated natural glasses: Amer. Mineral., v. 52, p. 280-286.

Noblett, J. B., 1981, Subduction-related origin of the volcanic rocks of the Eocene Clarno Formation near Cherry Creek, Oregon: Oregon Geology, v. 43, p. 91-99.

Park, Jr., C. F., and MacDiarmid, R. A., 1975, Ore deposits, 3rd ed.: San Francisco, Freeman, 530 p.

Parker, D. J., 1974, Petrology of selected volcanic rocks of the Harney Basin, Oregon (abstr.): Corvallis, Oregon State University, unpublished Doctoral thesis.

Parry, W. T., Ballantyne, J. M., Bryant, N. L., and Dedolph, R. E., 1980, Geochemistry of hydrothermal alteration at the Roosevelt Hot Springs thermal area, Utah: Geochim. et Cosmo. Acta, v. 44, p. 95-102.

Peterson, N. V., and Groh, E. A., 1969, The ages of some Holocene volcanic eruptions in the Newberry Volcano area, Oregon: Ore Bin, v. 31, no. 4, p. 73-87.

Pohn, H. A., 1981, Joint spacing as a method of locating faults: Geology, v. 9, p. 258-261.

Raisz, E., 1941, Landforms of the Northwestern states: Harvard, 3rd ed., 1965, scale 1:1,250,000.

Rantala, R. T. T., and Loring, D. H., 1973, New low-cost Teflon decomposition vessel: Atomic Absorp. News., v. $12, \mathrm{no} .4, \mathrm{p} \cdot 97-99$.

Reed, G. C., 1946, Exploration of Glass Buttes mercury deposit, Lake County, Oregon: U. S. Bur. Mines Report Inv. $3926,4 \mathrm{p}$.

Roquemore, G., 1980, Structure, tectonics, and stress field of the Coso Range, Inyo County, California: Jour. Geophysical Res., v. 85, p. 2434-2440. 
Rose, A. W., and Burt, D. M., 1979, Hydrothermal alteration, in Barnes, H. L., ed., Geochemistry of hydrothermal ore deposits, 2d ed.: New York, John Wiley and Sons, p. $173-235$.

Ross, C. P., 1941, Some quicksilver prospects in adjacent parts of Nevada, California and Oregon: U. S. Geol. Survey Bull. 931-B, p. 33-36.

Ross, C. S., and Smith, R. L., 1961, Ash-flow tuffs: Their origin, geologic relations, and identification: U. S. Geol. Survey Prof. Paper 366, $81 \mathrm{p}$.

Rytuba, J. J., and Glanzman, R. K., 1979, Relation of mercury, uranium and lithium deposits to the McDermitt caldera complex, Nevada-Oregon: Nev. Bur. Mines and Geol. Report 33, p. 109-117.

Schoen, R., White, D. E., and Hemley, J. J., 1974, Argillization by descending acid at Steamboat Springs, Nevada: Clays and Clay Min., v. 22, p. 1-22.

Schuette, C. N., 1938, Quicksilver in Oregon: Oregon Dept. Geol. Min. Ind. Bull. 4, $172 \mathrm{p}$.

Schwartz, G. M., 1955, Hydrothermal alteration as a guide to ore: Econ. Geol., Fiftieth Anniversary Vol., 19051955: p. 300-323.

Sheridan, M.F., 1980, Pyroclastic block flow from the September, 1976, eruption of La Soufriere Volcano, Guadeloupe: Bull. Volcan., v. 43, p. 397-402.

Steiner, A., 1953, Hydrothermal rock alteration at Wairakei, New Zealand: Econ. Geol., v. 48, p. 1-13.

1968, Clay. minerals in hydrothermally altered rocks at Wairakei, New Zealand: Clays and Clay Min., v. 16, p. 193-213.

Steven, T. A., and Lipman, P. W., 1976, Calderas of the San Juan Volcanic Field, southwestern Colorado: U. S. Geol. Survey Prof. Paper 958, 35 p.

Stewart, J. H., Walker, G. W., and Kleinhampl, F. J., 1975, Oregon-Nevada lineament: Geology, v. 3, p. 265-268.

Tatlock, D. B., 1966, Rapid modal analysis of some felsic rocks from calibrated $X$-ray diffraction patterns: U. S. Geol. Survey Bull. 1209, 41 p. 
Tchalenko, J. S., 1970, Similarities between shear zones of different magnitudes: Geol. Soc. Amer. Bull., v. 81, p. 1625-1640.

Thompson, K. C., and Reynolds, R. J., 1978, Atomic absorption, fluorescence and flame emission spectrorscopy, a practical approach: New York, John Wiley and Sons, $319 \mathrm{p}$.

Walker, G. W., 1969, Geology of the High Lava Plains province, in Mineral and Water Resources of Oregon; Oregon Dept. Geol. Min. Ind. Bull. 64, p. 77-79.

1970, Cenozoic ash-flow tuffs of Oregon: Ore Bin, v. 32, p. 97-105.

1973, Preliminary geologic and tectonic maps of Oregon east of the 121st meridian: U.S. Geol. Survey Misc. Field Study Map MF-495, scale $1: 1,000,000$.

1974, Some implications of late Cenozoic volcanism to geothermal potential in the High Lava Plains of south-central Oregon: Ore Bin, v. 36, p. 109-119.

1979, Revisions to the Cenozoic stratigraphy of Harney Basin, southeastern Oregon: U.S. Geol. Survey Bull. $1475,35 \mathrm{p}$.

Walker, G. W., Peterson, N. V., and Greene, R. C., 1967, Reconnaissance geologic map of the east half of the Crescent quadrangle, Lake, Deschutes, and Crook Counties, Oregon: U.S. Geol. Survey Misc. Geol. Invest. Map I-493, scale 1: 250,000.

Walker, G. W., and MacLeod, N.is., 1977, Rhyolitic volcanism in southeastern Oregon and the Sraike River Plain, Idaho: similarities and contrasts: Ore Bin, v. 36, p. 109-119.

Walker, G. W., and Nolf, B., 1981, High Lava Plains, Brothers fault zone to Harney Basin, Oregon, in Guides to some volcanic terranes in Washington, Idaho, Oregon and northern California: U.S. Geol. Survey Circ. 838, p. 105-118.

Ward, S. H., Parry, W. T., Nash, W. P., Sill, W. R., Cook, K. L., Smith, R. B., Chapman, D. S., Brown, F. H., Whelan, J. A., and Bowman, J. R., 1978, A summary of the geology, geochemistry and geophysics of the Roosevelt Hot Springs thermal area, Utah: Geophysics, v. $43, \mathrm{p} \cdot 1515-1542$. 
Waters, A. C., 1927a, Structural and petrographic study of the Glass. Buttes, Lake County, Oregon: Seattle, University of Washington, unpublished Masters thesis.

1927b, Structural and petrographic study of the

Glass Buttes, Lake County, Oregon: Jour. Geol., v. 35, p. 441-452.

Wells, R. E., 1979, Drake Peak - A structurally complex rhyolite center in southeastern Oregon: U. S. Geol. Survey Prof. Paper 1124-E, p. E1-E16.

Wheeler, R. L., and Dixon, J. M., 1980, Intensity of systematic joints: Methods and applications: Geology, v. 8, p. 230-233.

White, D. E., 1955, Thermal springs and epithermal ore deposits: Econ. Geol., Fiftieth Anniversary Vol., $1905-1955 ;$ P. 392-423.

1981, Active geothermal systems and hydrothermal ore deposits: Econ. Geol. Seventy-Fifth Anniversary Vol., p. 392-423.

Williams, H., Turner, F. J., and Gilbert, C. M., 1954 , Petrography: An introduction to the study of rocks in thin sections: San Francisco, Freeman, 406 p.

Williams, H., and McBirney, A. R., 1979, Volcanology: San Francisco; Freeman, Cooper and Company, $397 \mathrm{p}$.

Yoder, Jr., H. S., 1973, Contemporaneous basaltic and rhyolitic magmas: Amer. Miner., v. 58, p. 153-171.

Zielinski, R. A., Lipman, P. W., and Millard, Jr., H. T., 1977, Minor element abundances in obsidian, perlite and felsite of calc-alkalic rhyolites: Amer. Miner., v. 62, p. 426-437. 


\section{APPENDIX}

The following chemical analyses are presented here: XRF major oxide data performed for this study on 25 rock samples, including 1) raw data, and 2) data recalculated to 100 percent volatile-free and total iron as $\mathrm{FeO} ; \mathrm{AAS}_{2} \mathrm{O}$ data for 8 samples. All values are in weight percent.

Five other oxides were anallyzed for, using AAS methods. A large amount of error was introduced in these analyses by repeated dilutions required to lower element concentrations into instrument detection ranges. The AAS technique further requires precise chemical treatments of solutions to minimize interference to ionization, as well as to enhance or prevent excessive ionization. Due to this complex procedure, data obtained by AAS was compared to XRF analyses by an outside laboratory, which indicated close agreement of $\mathrm{K}_{2} \mathrm{O}$ data, while other oxides varied as much as several weight percent. Because of the greater completeness and reliability of the XRF data, it has been used exclusively in this report.

Previously published analyses of Glass Buttes rocks are also included here. Operating parameters for X-ray diffraction arelisted following all chemical analyses. Analytical procedures followed for AAS and X-ray diffraction studies are given by Carroll (1970), Kirkbright 
and Sargent (1974), Langmyhr and Paus (1968), Rantala and Loring (1973), and Thompson and Reynolds (1978). 


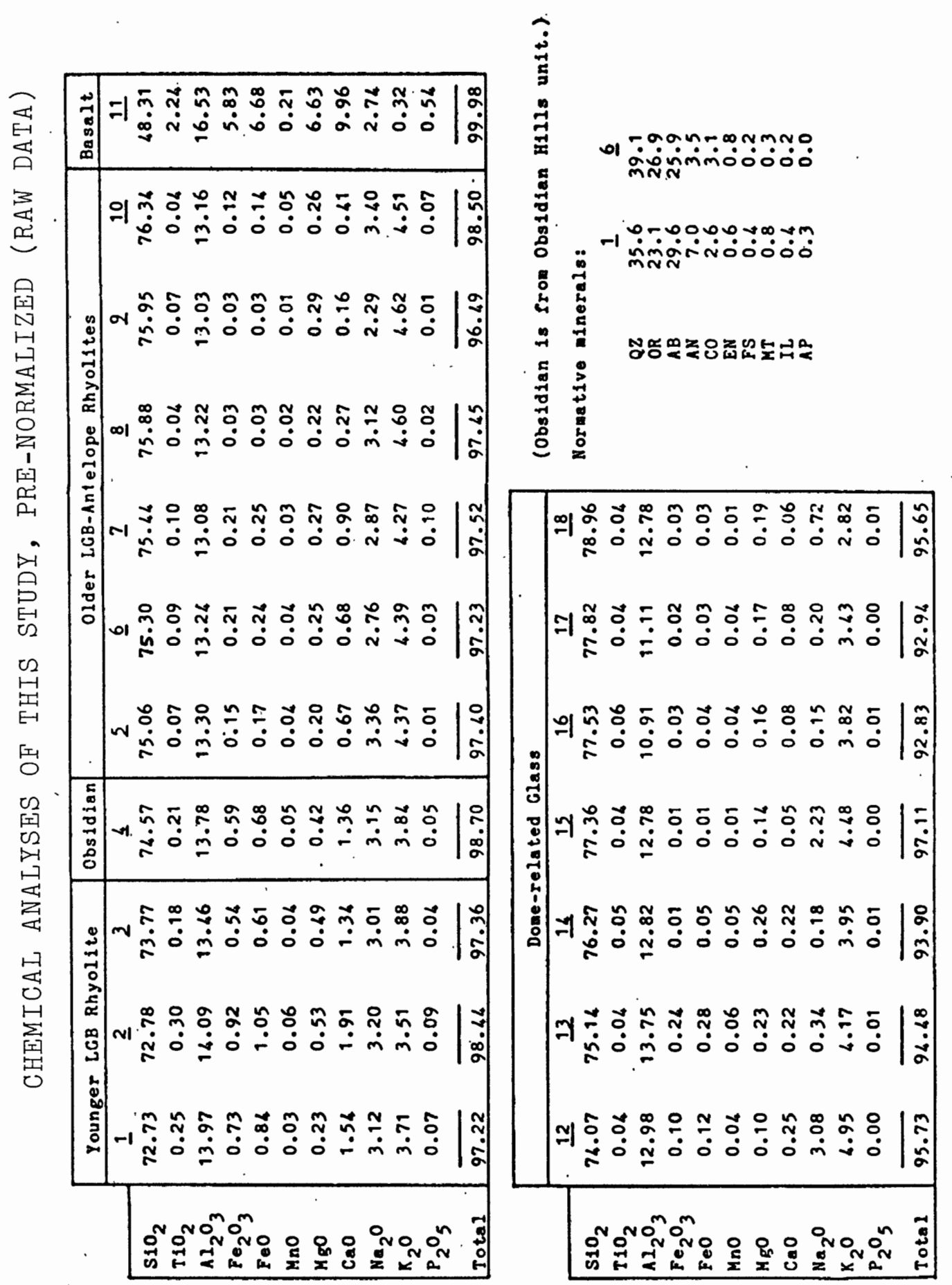




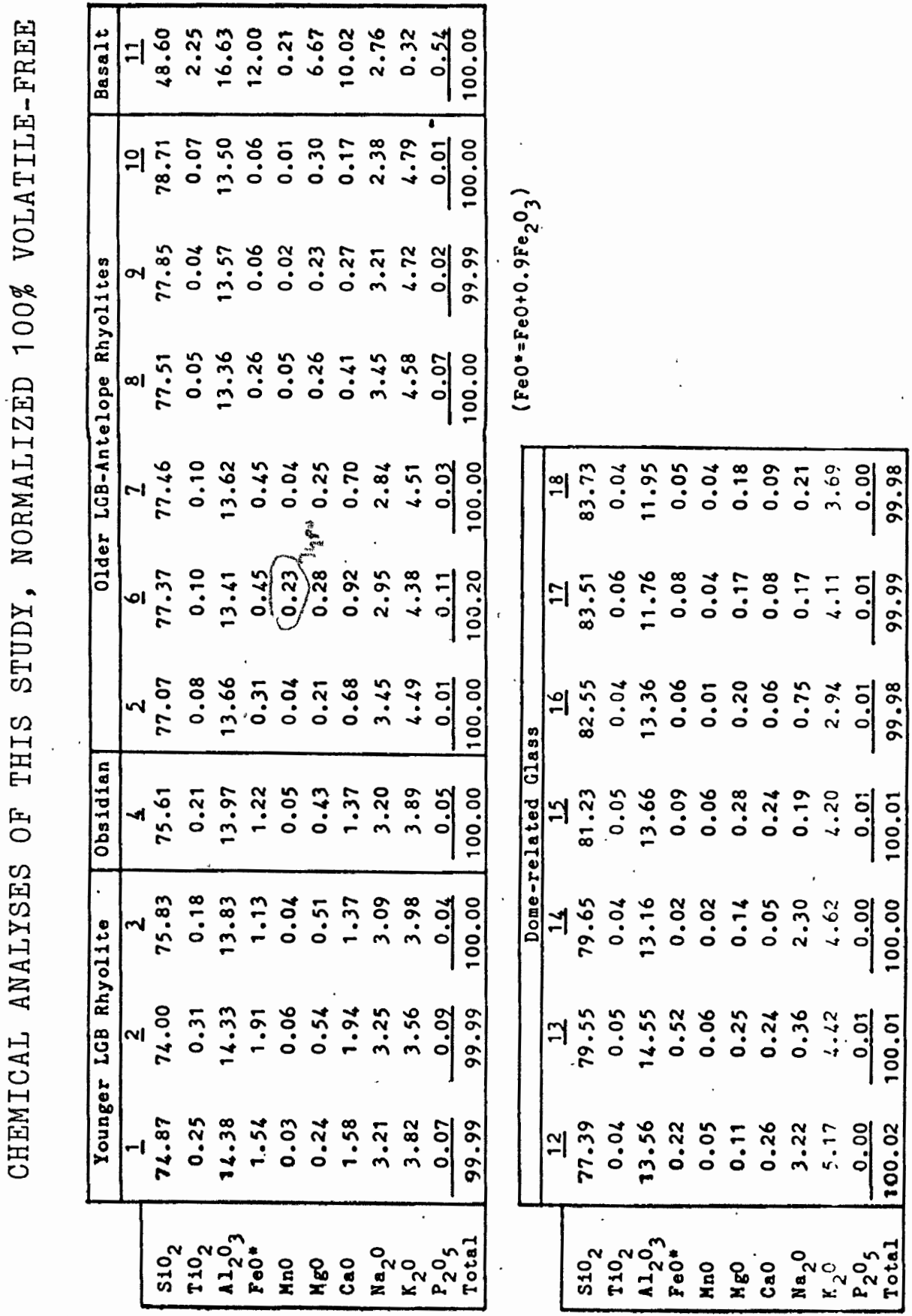


Analyses from Beeson (1969)

Rhyolitic lava (0-10) and rhyolitic obsidian (0-11) from Glass Buttes, Oregon.

$$
\underline{0-10} \quad \underline{0-11}
$$

$\begin{array}{lcc}\mathrm{Na} \% & 2.89 \pm 0.5 & 2.85 \pm 0.5 \\ \mathrm{Cs} & 4.3 \pm .2 & 4.8 \pm .2 \\ \mathrm{La} & 21 \pm 3 & 14.2 \pm .6 \\ \mathrm{Ce} & 41 \pm 3 & 32.1 \pm 1.2 \\ \mathrm{Sm} & 4.57 \pm .12 & 9.1 \pm .2 \\ \mathrm{Eu} & 0.56 \pm .04 & 0.28 \pm .03 \\ \mathrm{Lu} & 0.85 \pm .10 & 1.56 \pm .05 \\ \mathrm{Th} & 11.7 \pm .7 & 16.9 \pm .6 \\ \mathrm{Hf} & 4.76 \pm .13 & 5.3 \pm .5 \\ \mathrm{Ta} & 0.9 \pm .2 & 1.24 \pm .18 \\ \mathrm{Mn} & 347 \pm 11 & 420 \pm 60 \\ \mathrm{Co} & 0.43 \pm .13 & \text { not counted } \\ \mathrm{Fe} \% & 0.529 \pm .016 & 0.48 \pm .17 \\ \mathrm{Sc} & 3.26 \pm .06 & 8.4 \pm .3 \\ \mathrm{Eu} / \mathrm{Sm} & 0.122 & 0.031 \\ \mathrm{La} / \mathrm{Sm} & 4.6 & 1.56\end{array}$


Analysis from MacLeod and others (1976)

Glass Butte dome rock, sample no. 7

$\mathrm{SiO}_{2}$

75.7

$\mathrm{AI}_{2} \mathrm{O}_{3}$

13.4

$\mathrm{Fe}_{2} \mathrm{O}_{3}$

0.26

$\mathrm{FeO}$

0.56

$\mathrm{MgO}$

0.09

$\mathrm{CaO}$

0.90

$\mathrm{Na}_{2} \mathrm{O}$

3.8

$\mathrm{K}_{2} \mathrm{O}$

3.7

$\mathrm{H}_{2} \mathrm{O}^{-}$

0.39

$\mathrm{H}_{2} \mathrm{O}^{+}$

0.04

$\mathrm{TiO}_{2}$

0.10

$\mathrm{P}_{2} \mathrm{O}_{5}$

$\mathrm{MnO}$

0.06

Analysis from Jack and Carmichael (1969)

Glass Butte, Oregon, sample no. 4 (Cäm 146)

K $\quad 3.26$

$\mathrm{Ti} \quad 520$

$\mathrm{Mn} \quad 405$

Co 20

$\mathrm{Ni} \quad 5$

$\mathrm{Cu} \quad 5$

Zn 30

$\mathrm{Ga} \quad 15$

$\mathrm{Rb} \quad 80$

$\mathrm{Sr} \quad 30$

$Y .45$

$\mathrm{Zr} \quad 95$

$\mathrm{Nb} 10$

$\mathrm{Ba} \quad 1300$

La 40

$\mathrm{Ce} \quad 90$

$\mathrm{Pr} \quad 5$

Nd 25

$\mathrm{Pb} \quad 10$

Th 10 
X-ray Diffraction Operating Parameters:

$40 \mathrm{KV}$

$20 \mathrm{Ma}$

Soller Slit MR

Time constant 4.0 seconds

Rate meter $500 \mathrm{cps}$

Beam Tunnel $1^{\circ}$

Detector slit $0.1^{\circ}$

Gain $16 / 87$

Scan speed $2^{\circ} 2 \theta /$ minute

Chart speed 1 inch/minute 